\title{
Yahya Kemal'in Yakın Dönem Türk Siyaset ve Edebiyatına Dair Gün Yüzüne Çıkmamıș Bazı Hatıra ve Notları
}

\section{Some Memoirs and Notes of Yahya Kemal Previously Unrevealed on Recent Turkish Politics and Literature}

\section{Mehmet Samsakç1 $1^{1}$ (1)}

'Doç. Dr., İstanbul Üniversitesi, Edebiyat Fakültesi, Türk Dili ve Edebiyatı Bölümü, İstanbul, Türkiye

\section{ORCID: M.S. 0000-0002-7855-6557}

Sorumlu yazar/Corresponding author: Mehmet Samsakçı,

İstanbul Üniversitesi, Edebiyat Fakültesi, Türk Dili ve Edebiyatı Bölümü, İstanbul, Türkiye

E-mail: samsakci@istanbul.edu.tr

Başvuru/Submitted: 15.11.2019

Kabul/Accepted: 17.12 .2019

\section{Atıf/Citation:}

Samsakci, M. (2019). Yahya Kemal'in yakın dönem Türk siyaset ve edebiyatına dair gün yüzüne çıkmamış bazı hatıra ve notları. TUDED 59(2), 399-448.

https://doi.org/10.26650/TUDED2019-0031

\section{ÖZET}

20. yüzyıl Türk şiirinin kurucu kalemlerinden birisi olan, 1912'de Paris'ten İstanbul'a döndükten çok kısa bir süre sonra sohbetleriyle, dersleriyle ve az sayıda da olsa neşrettiği şiirleriyle tefekkür, zevk ve estetiğini kabul ettiren Yahya Kemal, 74 yaşında vefat etmiş olmasına yani uzun sayılabilecek bir ömür sürmesine rağmen sağlığında kitap yayımlamamıştır. Mütareke / Millî Mücadele ve Cumhuriyet dönemlerini idrak eden, bu yıllarda özellikle gazete yazılarına ağırlık veren Yahya Kemal'in kitapları, terekeden çıkan el yazısı müsveddeleri, devrin gazete ve dergilerinde yazdığı yazı ve şiirleriyle dostlarına gönderdiği mektup vs. belgelerin oluşturduğu bir külliyât teşkil etmektedir. Bilindiği gibi Yahya Kemal, hayattayken kitap yayımlamamıştır. Bu şiir, yazı ya da notlar, şairin vefatından sonra İstanbul Fetih Cemiyeti bünyesinde kurulan ve șairin vârisleriyle bir protokol imzalayan Yahya Kemal Enstitüsü tarafından yayımlanmıștır. Fakat 12 kitaplık bu külliyât, çeşitli zamanlarda, çeşitli araştırmacılar tarafından zenginleştirilmekte, genişletilmektedir. Zira yeni araştırmalar, yeni taramalar, gün yüzüne çıkan yeni arşivlerde Yahya Kemal'e ait yazı ve mısralar ortaya çıkarmaktadır. Bu yazı da bir süre önce İstanbul Şehir Üniversitesi tarafından erișime ve paylaşıma açılan Taha Toros Arşivi'nde bulunan ve Yahya Kemal'e ait olan 18 adet yazı ve hatıranın çeviriyazısını içermektedir.

Anahtar Kelimeler: Yahya Kemal, Türk tarih, siyaset ve edebiyatı, Taha Toros Arşivi

\section{ABSTRACT}

Yahya Kemal, one of the founding writers of $20^{\text {th }}$-century Turkish poetry, soon established his ideas, taste and aesthetics with his conversations, lectures, poems and articles which he published shortly after his return from Paris to Istanbul in 1912. Although he passed away at the age of 74, which meant he had had a long life, he did not publish a book when he was alive. Yahya Kemal, who experienced the years of the occupation, the National Struggle and the Republican period, focused on newspaper articles during those years. His books, handwritten manuscripts, poems and articles published in the newspapers of that time, and also the documents and letters he sent to his friends, form the corpus of his writing. As is well known, Yahya Kemal did not publish a book while he was alive. These poems, writings or notes were published by the Yahya Kemal Institute, which was established within the Istanbul Conquest Society, after the death of the poet, and the same Istitute signed an agreement with his heirs.

However, this collection of 12 books has been enriched and expanded by several researchers at various times since new research, studies and archives have continued to reveal the writings and verses belonging to Yahya Kemal. This article contains the transcriptions of 18 articles and memoirs of Yahya Kemal in the Taha Toros Archive, which has recently been accessed and shared by Istanbul Şehir University.

Keywords: Yahya Kemal, Turkish history, politics and literature, Taha Toros Archive 


\section{EXTENDED ABSTRACT}

One of the significant personal traits of Yahya Kemal in the history of Turkish literature is his perfectionism and the fact that he did not publish any books while he was alive. Yahya Kemal, who frequently reflected upon and edited his writings, especially his poems, even continued to work on his finished works.

Before he passed away at the age of 74, Yahya Kemal increased his studies on his books towards the end of his life, having been persuaded by his friends, followers and readers to publish books throughout his life. He even made three poetry books ready for publication with his friends namely Ahmet Hamdi Tanpınar and Nihad Sami Banarlı. It is also well known that he even brought special papers from Europe for those books. However, it was not possible to publish the books. The Yahya Kemal Institute, which was established following his death under the Istanbul Conquest Society, signed an agreement with the legal heirs of the poet and began publishing the books one after the other. The first book, Kendi Gök Kubbemiz, was published in 1962.

Those books, four of which are poetry and eight are prose, consist of poems and articles published by Yahya Kemal in magazines, newspapers or anthologies and also include his handwritten manuscripts.

The authorities and employees of the Institute examined the magazines and newspapers he wrote until 1958, the year of his death, and his poems and writings were classified according to their subjects and then published in book form.

However, the fact that dozens or even hundreds of magazines and newspapers were published between these years made it difficult or even impossible to form a complete list.

Because Yahya Kemal, especially during the National Struggle, concentrated on prose, he published dozens of articles on history, politics, culture and literature. In fact, some of them were not published in his own name but under pseudonyms or nicknames due to the strict censorship of the occupation forces. In short, it is not possible to form a comprehensive collection even of the writings published by Yahya Kemal under his own name. In addition, the necessity of determining whether some writings belong to Yahya Kemal or not poses separate problems.

Despite all the well-intentioned efforts and the use of opportunities provided by technology, and even taking into account the various collections and catalogs that have been available for access, nonetheless a comprehensive catalog of the author's periodical publications has not yet been put together in Turkey. Some collections are also quite old and incomplete. Therefore, a complete list of the works of many poets and writers such as Yahya Kemal cannot be made.

Throughout all the years that have passed, the fact that many archives, both individual and institutional, have been brought to light and opened to access has enabled many a deficiency to be eliminated. Large collections such as the Atatürk Library and Hakkı Tarık Us Library's 
Newspaper and Magazine Catalog have been opened on-line. In addition, it is a great benefit that the archive of Taha Toros, a researcher, has been digitized and shared by Şehir University. In this way, the documents that have been entered into the Taha Toros Archive at various times and in various ways are made available to the public.

18 writings and notes of Yahya Kemal, which the reader will see in their transcribed versions in this article, have been made available from the Taha Toros Archive. Those writings, written by the poet at various times in different cities and even in different countries, are mainly about politicians, poets and writers whom he had the chance to meet. Yahya Kemal's observations on the political characteristics of the Young Turks, whom he knew about when he was in Paris between 1903 and 1912, provide valuable data for today's researchers studying the period in question.

Some of those 18 writings include the findings and evaluations of Yahya Kemal, whose historical knowledge is extremely advanced. The historical events and personalities that the poet thinks of while passing by the Prut Plain particularly provide us with very original perspectives. Some of these writings provide vivid lines directly about Yahya Kemal's personal development in poetry and literature. Yahya Kemal studied politics and history in Paris, but in those years he was more interested in poetry and literature than perhaps his subjects. During those 9 years, Yahya Kemal benefited from one of the largest libraries in Paris. He studied important sources of Turkish history and literature and acquired a very deep and original background. He soon shared them with the Turkish public. These articles contain important clues about Yahya Kemal's poetic career. In addition, it is possible to observe where a young poet candidate sought poetry and how he formed his own poetry universe. In these articles, published for the first time in this study, it is revealed who Yahya Kemal reads, which art and literary circles he is part of in Paris and in which European schools of poetry and art he is interested. 
Yaşadığg sürede ve sonrasında, Yahya Kemal'in zihinlerde yer eden en büyük özelliği, sağlığında kitap neşretmemesidir. Bu yüzden sayısız tariz ve tenkide uğrayan fakat Orhan Seyfi'nin, Resimli Dünya için kendisiyle yaptığı röportajda böylesi bir şöhretten memnun bile olduğunu söyleyen (Beyatlı, 1997, s. 109) Şair, kendisiyle yapılan mülâkatlarda bu duruma dair açıklamalar yaptıysa da esas sebep O’nun, sadece Türk edebiyatında değil, dünya edebiyatında dahi benzeri pek görülmeyen mükemmeliyetçiliğidir. Üzerinde yıllarca çalıştığı mısra ve şiirleri daima düşünmeye, kendi tabiriyle "yoğurmaya" devam eden Yahya Kemal'in, vefatına yakın, kitap konusunda artık ikna olduğu, şiirlerini tasnif ettiği, bugün elimizde olan şiir kitaplarının bazılarının ismini belirlediği hatta basılacak kitaplar için Fransa'dan kâğıt sipariş ettiği de bilinmektedir. (Yetiş, 1998, s. 200)

Yahya Kemal'in, Pakistan' dan gönderdiği 15 Haziran 1948 tarihli bir mektubunda “Hasretle, hürmetle, muhabbetle gözlerinizden öperim" diye hitap ettiği Nihad Sami Banarlı, (Beyatl, 1997b, 266) Şair'in 1 Kasım 1958'deki vefatından çok kısa bir süre sonra, Yahya Kemal'in de âzâsı olduğu İstanbul Fetih Cemiyeti bünyesinde bir Yahya Kemal Enstitüsü kurmuş, vârislerle anlaşarak daha önce mecmua, gazete veya ortak kitaplarda neşredilmiş eserlerle, el yazısı hâlinde kalmış not ve yazıları peyderpey yayımlamıştır. (Samsakçı, 2008a, s. 456-471; Samsakçı, 2008b, s. 462-471) Banarlı, defin meselelerinin ortasında Park Otel'e giderek Şair'in kaldığg odanın kapısını kilitletmiş, bu sayede paha biçilmez pek çok evrakı unutulmaktan kurtarmış ve ağır mesaisinin arasında bu evrakı tam bir titizlikle tasnif ederek asistanlarıyla birlikte neşre başlamıştır. (Yetiş, 1998, s. 204) Bir tesahup itham ya da tenkidinden çekinerek veya inhisarcı davranmadığını göstermek için özellikle ilk ve en mühim kitap olan Kendi Gök Kubbemiz'in baskıdan bir önceki provasını Prof. Ahmet Hamdi Tanpınar, Prof. Necmeddin Halil Onan, Prof. Dr. Faruk Kadri Timurtaş gibi dil ve edebiyat üstatlarına göndermiş, onların görüş, tenkit ve tavsiyeleri doğrultusunda kitapları önemli önsözlerle neşretmiş hatta her kitabın neşrini bir toplantıyla taçlandırmıştır.

Namık Kemal'in eserlerinin neşri ve kaybolmasına izin vermeme bağlamında çok büyük bir gayreti olan Ebuzziya Tevfik'i andıran bir gayret ve sadakatle çalışan, bu yönüyle bir anlamda aslında Yahya Kemal'in editörü olan Nihad Sami Banarlı, Kendi Gök Kubbemiz, Eski Şiirin Rüzgârlyle ve Rubaîler ve Hayyam Rubâilerini Türkçe Söyleyiş hariç diğer eserlerin başlıklarını da belirlemiştir. Banarlı, Yahya Kemal'in, Enstitü'ye kazandırılan el yazısı müsveddelerini, makale ve konferans taslaklarını bir bir Lâtin harflerine çevirip notlandırarak baskıya hazırladığı gibi, belki Yahya Kemal'in kendisinin dahi hatırlayamayacağı şiir, yazı ve röportajları 40-45 yıllık matbuatı tarayarak tespit etmiş, hatta bazı rumuzlu yazıların Yahya Kemal'e aidiyetini belirlemiştir. Geriye dönük bu arkeolojik faaliyetten sonra, Yahya Kemal Enstitüsü olarak söz konusu yıllarda medya takibi hizmeti veren bir ajansla anlaşarak Yahya Kemal hakkında matbuatta çıkan her satırı arşive kazandırmıştır.

Eserlerini kitap hâlinde neşretmeyi sürekli ertelese, dost ve hayranlarının bu konudaki rica ve ısrarlarına müspet cevap vermese hatta bazı kimselerin bu kitapların neşrini kendi uhdelerine 
alma tekliflerine tatlı-sert cevaplar vermişse de ${ }^{1}$ (Beyatl1, 1997b, s. 91-92) Yahya Kemal'in, çok çalışkan, aslında yazmaktan ve konuşmaktan bıkmayan bir şahsiyet olduğu muhakkaktır. Öylesine muhakkaktır ki Banarlı ve asistanlarının bu ciddî, özverili mesailerinden başka arkadan gelen araştırmacı ve akademisyenler dahi Yahya Kemal Külliyatı denen büyük kâinatı ihataya muktedir olamamışlardır. Bugün 12 kitaptan oluşan külliyatın neşrinden yıllar sonra da Yahya Kemal'in bazı mısra, makale, mektuplarıyla konferans metinleri çeşitli akademisyen ya da araştırıcılar tarafından tespit ve çeşitli mecralarda neşredilmiştir. (Çoruk, 2018, s. 345-373; Samsakçı, 2019a, s. 40-44)

\section{Mevcut Külliyâtta Yahya Kemal'in Edebî ve Siyasî Yazıları}

Yahya Kemal Enstitüsü, yukarıda belirtildiği gibi Şair'in şiirleri gibi mensur eserlerini de belirli bir mantığa dayanarak, muhteva özellikleri ve konu bütünlüğüne riayet ederek arka arkaya neşretmiştir. Meselâ Ĕgil Dağlar, Yahya Kemal'in, Mütareke dönemi boyunca, kimisi “*** rumuzuyla ve pek çok yeri sansürlenmiş olarak çeşitli gazetelerde neşrettiği İstiklâl Savaşı'yla ilgili yazılarının toplandığı eserdir. Millî Mücadele, çok net bir mevzu olduğu ve bu yazılar belirli bir tarih aralığında, belirli bir hissiyât ve üslûpla kaleme alındıkları için Yahya Kemal'in hangi makalelerinin bu kitaba girmesi konusunda büyük bir tereddüt yoktur. Bununla beraber Şair'in eserlerinin İstanbul Fetih Cemiyeti ile Yapı Kredi Yayınları tarafından ortaklaşa basımı için yapılan bir protokol çerçevesinde Yahya Kemal Enstitüsü Müdürü Prof. Dr. Kâzım Yetiş, metinlerin asıllarına giderek yaptığı “edisyon kritik”te bu kitapta yer alması ve almaması gereken metinleri tespit etmiştir. Yani Yahya Kemal'in bu konuda kaleme aldığ 1 ama eserin önceki baskılarında yer almayan bazı yazıları kitaba derç etmiş, buna mukabil önceki baskılarda bulunan ama Millî Mücadele ile doğrudan ilgisi bulunmayan makaleleri çıkarıp başka kitaplara almış, bu sayede kitap daha insicamlı ve derli toplu bir içeriğe kavuşmuştur. ${ }^{2}$ Tarih ve siyasete yer verdiği dikkati çekse ve güncel meseleleri genellikle belirli bir tarihî süreci vererek değerlendirdiği görülse de bu kitapta Yahya Kemal'in oldukça aktüel olduğu göze çarpar. Bunlar, Millî Mücadelenin belki acı, ıstırap ve endişelerini barındıran ama bir azim ve ümidi de muhafaza eden, sıcak yazılardır.

Yahya Kemal'in portre, hatıra, ayrıca "anı-portre" türünden yazıları ise 3 ayrı kitapta neşredilmektedir. Bunların ilki Şair'in görüştüğü, tanıdığ hakkındaki değerlendirmelerinin bulunduğu Siyasî ve Edebî Portreler'dir.

1 Yahya Kemal, 1931 yılında, Madrid elçisiyken, Fazıl Ahmet Yenisey’e hitaben kaleme aldığı bir mektupta şunları söylemektedir: "Defterinizde müstensah bulunan bazı manzumelerimin bir kitap hâlinde tarafinızdan tab'l ve neşredilmesi için ifade buyurduğunuz tekliften mütehayyir ve müteessir olduğumu ketmetmeyeceğim. Şüphem yoktur ki bu teklifi bana olan dostane hissiyatınızın bir ifadesi olarak dermeyan buyuruyorsunuz. Ancak bir insanın hayatta kendi eserini bizzat neşir ve tab' etmesi en tabiî ve en iptidaî hakkıdır. Her müellif kendi eserinin tab'ında alması iktiza eden şekli kendi tayin etmelidir. Bahusus ki, defterinizde olan manzumelerimin bir küll teşkil etmedikleri muhakkaktır; bana ait olmayan misralarla, sözde, ikmal edilmiş olmaları da vârid-i hatırdır. Manzumelerimin hepsini kendim cem'ederek ve bizzat tab'ettirerek âcizane bir eser vücuda getirmek niyetindeyim. Bunun için dermeyan buyurduğunuz teşebbüsten beni affetmenizi rica ederim."

2 Protokol sonunda Yahya Kemal Enstitüsü tarafindan yapılmakta olan neşirler de aynı içerikle gerçekleştirilmektedir. Hangi yazıların esere dâhil edildiği ve hangilerinin çıkarıldığı ile ilgili izahlar da eserleri başında yapılmıştır. Bu bağlamda Prof. Yetiş, ortak basım çerçevesinde çıkan diğer eserlerde de bazı gerekli tasarrufları yapmıştır. 
Şair'in memleketi Üsküp'e, bir ara bulunduğu Selânik’teki günlerine, ailesine, çocukluğunda şahsiyeti üzerinde mühim tesirleri olan uşak, dadı, lala gibi insanlara; ilk tahsil macerasına, İstanbul'a gelişi ve Paris'e firarına; Paris’teki - daha çok da şiir ve sanatla geçen - tahsil yıllarına; asıl şiiri, Türk tarihi, kültürü ve milliyeti mevzularındaki arayışlarına; tanıdığı Jön Türkler'e, Meşrutiyet ve sonrasındaki siyasî kişilik ve hadiselere dair yazıları, kuşatıcı bir başlık altında Çocukluğum, Gençliğim, Siyasî ve Edebî Hatıralarım adıyla neşredilmektedir.

Yahya Kemal'in bu mevzulardaki diğer hatıraları ise Nihad Sami Banarlı imzasıyla neşredilen Yahya Kemal'in Hatıraları'dır. Yahya Kemal'in konuşmalarının kaydedilmesi noktasındaki hassasiyeti ve bu imtiyazı - gazete ve dergi için röportaj yapanlar hariç - Banarlı'dan başka hiç kimseye tanımaması hatırlanırsa bu kitabın mühim ve ayrıcalıklı tarafı, Nihad Sami Banarlı'ya anlattığ 1 hatıralarıdır. Bu kitaptaki diğer hatıralar ise Yahya Kemal'in el yazısıyla olanlarıdır ki bunların bazısı aynı zamanda Çocukluğum, Gençliğim, Siyasî ve Edebî Hatıralarım'da, (örn. “Şiirde Otuz Senem”, “Fransa'da Şiir”) kimisi de Siyasî ve Edebî Porteler'de (örn. "Tevfik Fikret”, “Ahmet Naim Bey’e Dair Bir Hatıra”) neşredilmektedir.

Şair'in Türk ve Avrupa tarihine dair yazdığı metinler ve tuttuğu notlar da Yahya Kemal Külliyatının 11. kitabı olarak, Tarih Musahabeleri adıyla Banarlı'nın asistanlarından Nermin Suner tarafından neşredilmiştir.

\section{Taha Toros Arşivi ve Arşivde Yer Alan Portre ve Hatıralara Dair}

Daha önce dikkati çekmemiş, çekse dahi üzerinde çalışılma gereği görülmemiş bu metinlerin, Kasım 2018'de İstanbul Üniversitesi'nde gerçekleştirilen “Evvel Giden Ahbâb: Vefatının 60. Yıldönümünde Yahya Kemal Beyatlı" isimli panelde sunulan "Yahya Kemal ve İstanbul Üniversitesi” başlıklı çalışmamız esnasında tespit edildiğini öncelikle vurgulamamız gerekmektedir. ${ }^{3}$ (Samsakçı, 2019b, s. 60-72) Bizim bu çalışmada neşredeceğimiz not, yazı, hatıra ve eskizler Yahya Kemal'in dost halkası içinde bulunan ve Türk Edebiyatından Altı Renkli Portre isimli eserinin mühim bir kısmını Şair'e ayıran Taha Toros'un ${ }^{4}$, geçtiğimiz yıllarda İstanbul Şehir Üniversitesi tarafından dijitalize edilerek yayımlanan çok zengin arşivinde

3 Söz konusu sunum, metin hâline getirilip aynı başlıkla neşredilmiştir. Bu çalışmada Yahya Kemal'in, İstanbul Üniversitesi Edebiyat Fakültesi Sekreterine hitaben yazdığı ve bu arşivde tespit ettiğimiz çok samimî bir mektubu da neşretmiştik.

4 Aslında hukuk tahsil eden, hayatı boyunca da aldığı formasyon çerçevesinde görevler üstlenen Taha Toros, aynı zamanda büyük bir arşivcidir de. Aldığı vazifeler gereği Türkiye'nin her yerini gördüğünü söyleyen, gittiği her yerde de derleme çalışmaları yapmış olan, ayrıca evrensel çaptaki bazı büyük arşivleri inceleme fırsatı bulan Taha Toros, Yahya Kemal'in sohbet halkasına dâhildi. Bu arşivci şahsiyetin, dil, tarih, edebiyat, siyaset, folklor gibi alanlardakiler başta olmak üzere eline geçen her mühim evrakı profesyonel biçimde tasnif ederek muhafaza etmesi yadırganacak bir husus değilse de Yahya Kemal'in kendi el yazısıyla tuttuğu notların Taha Toros'a nasıl intikal ettiği belli değildir. Zira bilindiği kadarıyla bu notlar Yahya Kemal'in kendisinde mahfuzdu ve Park Otel'deki bavullarında bulunuyordu. Vefat sonrasında ise bu evrak, Enstitü tarafından vârislerden satın alınmış ve yine Enstitü bünyesindeki Yahya Kemal Müzesi’ne kazandırılmıştı. Esasında Enstitü ve Müze'nin kuruluş aşamasında Banarlı ve arkadaşlarının Yahya Kemal'le akrabalığı, dostluğu ya da âşinalığı olan insanlara ulaştığı, bu kişilerden Şair'e ait hatıralarının asıllarını ya da fotokopilerini rica ettiği bilinmektedir. 
tespit edilmiştir. ${ }^{5}$ Hakikaten İstanbul Şehir Üniversitesi vasıtasıyla ulaşma imkânı bulduğumuz Taha Toros Arşivi’nde bu külliyâtı ciddî oranda besleyecek, artıracak bir yekûn mevcuttur.

Portre, hatıra, makale, deneme, sohbet gibi türlere dâhil edilebilecek 14 siyasî ve 4 edebî içerikli yazıyı günümüz alfabesine çevirip verdiğimiz bu çalışmanın plânına dair birkaç izahta bulunalım:

Her şeyden evvel ifade edilmelidir ki Yahya Kemal'in bu yazıları tam olarak ne zaman yazdığı belli değildir. Bazıları başlıksız olan bu metinlerin ne zaman kaleme alındıklarını dair bir fikri, Şair'in kullandığg kâğıtların antetlerinden öğrenmek mümkün olabilmektedir. “T.B.M.M. Hususî” antetli kâğıtlardaki metinlerin, Şair'in Urfa, Tekirdağ, Yozgat ya da İstanbul milletvekillikleri zamanında yazıldığı kesindir. Bazılarında da Meclis'in "intihab devresi ve içtima senesi" bilgileri yer almaktadır bunlar da zamanı tayin konusunda net bilgi verir. (Fakat Yahya Kemal'in Urfa'dan sonraki milletvekilliklerinin Varşova ve Madrid elçiliklerinden sonraya denk gelmesi yıl aralığını açmaktadır. Meselâ 2. milletvekilliği olan Yozgat görevi 1934’te, yani ilkinden tam 11 yıl sonradır.) Aynı şekilde "Légation de Turqie - Madrid" antetli kâğıtlara yazılan metinlerinse 1929-1932 arasında kaleme alındıkları açıktır. Nitekim bu yazıların büyük çoğunluğu Madrid'de kaleme alınmıştır. Kaldı ki Yahya Kemal, bu tür musahabe ve hatıraları kaleme almak için Madrid'de zamanının olduğunu bir hatırada söylemektedir.

Aşağıda görüleceği gibi bazı yazılar eksiktir. Öyle ki bu metinler yarım cümlelerle, hatta "fakat" gibi bir kelimeyle son bulabilmektedir. Bundan anlaşılan, Şair’in mesaisinin böylesi metinlere bir daha dönmesini engellediği ya da başka bir hatıraya geçtiğidir.

Yahya Kemal, metin üzerindeki düzeltmelerini hemen kullandığı kâğıt üzerinde, hatanın üzerini çizmek şeklinde yapan, yazdıklarını temize çekmeyen birisidir. Buna rağmen zaten konuşma diliyle, okuyucusunu karşısında hissederek kaleme aldığ 1 bu musahabelerdeki cümlelerin, bilinen Yahya Kemal üslûbu oldukları göze çarpar. Hızlı yazdığı çok belli olan Şair'in, kaleminin mürekkebinin zaman zaman azalması, kaleme yeni mürekkep koyuluncaya kadarki yazıların okunmasını güçleştirse de bu yazıların okunaklı olmadığını söylemek güçtür.

Bu 18 yazıyı biz içeriklerine göre "edebî" ve "tarihî/siyaŝ̂" metinler şeklinde kompoze edip vermeyi uygun bulduk. Abdullah Cevdet, Ziya Gökalp / Halide Edip hakkında yazdı̆̆ musahabede görüleceği gibi bazen aynı zamanda edebî ve siyasî kimliği olan kişilerle ilgili metinler de mevcuttur. Bu noktada bu metinleri tasnif ederken, Yahya Kemal'in o yazıdaki bahse mevzu kişiyi hangi özellikleriyle anlattığını ve hangi özelliklere odaklandığını dikkate aldık.

5 İstanbul Şehir Üniversitesi'nin bu muazzam arşivi böylesi bir profesyonellik, ciddiyet ve cömertlikle kamuoyunun hizmetine sunması her türlü takdirin üzerindedir. Bununla beraber bu dijital arşivde "Yahya Kemal" adıyla kayıtlı olan her belge orijinal ya da Yahya Kemal'le ilgili değildir. Meselâ arşivde "Yahya Kemal'in Gaziantep Mebusu İken Kendi El Yazısıyla Yazmış Olduğu Bir Not” başlıklı, Suriye Tahdid-i Hudut Komisyonu'yla ilgili bir metin göze çarpmaktadır. Yahya Kemal, Gaziantep Mebusu olmadığı gibi, metindeki el yazısı da başkasına aittir. Yahya Kemal'in, Urfa Mebusu iken bu komisyonun âzâsı olduğu, yaptığı görüşmelerle ilgili Meclis'e raporlar sunduğu bir hakikattir ki bu metinler de yakında tarafımızdan neşredilecektir. 
Metinler hakkında kısa bir tenkit ve değerlendirme yapmak gerekirse:

\section{Edebiyatla İlgili Olanlar}

Arşivde doğrudan edebiyatla ilgili olan 4 metin yer almaktadır. "Paris’te Yeni Şiiri Arayış" diye başlıklandırdığımız ve "1908'e kadar şedit bir ihtirasla yalnız ve yalnız yeni bir şiirin ufuklarına doğru koşmuştum” " cümlesiyle başlayan ilk metinde Yahya Kemal, Paris yıllarında Tevfik Fikret ve Cenab Şehabeddin tarzı şiirin dışında nasıl bir şiiri özlediğini, Türkçede yazılması gereken şiiri nasıl ve nerelerde aradığını, kimleri okuduğunu, edebî terbiyesine, zevkine hayran olduğu dostu Jean Moréas'tan etkilenerek Sofokles, Racine, Horace gibi Batı klâsiklerinden etkilenerek bizim klâsiğimiz olan Divan şiirini nasıl keşfettiğini anlatır. Fakat divan şirinin mazmunlar dünyası içinde sevmediği kalıp ya da ifadeleri söz konusu etmekten geri kalmaz. Esasen Yahya Kemal, Çocukluğum, Gençliğim, Siyasî ve Edebî Hatıralarım ve Yahya Kemal'in Hatıraları'nda mükerrer olarak neşredilen "Şiirde Otuz Senem” başlı̆̆ altındaki satırlarda, Üsküp yıllarında şiire bir "aşkla" nasıl başladığını anlattıktan sonra Paris yıllarındaki yoklayışlarını, araştırmalarını zikretmektedir. Fakat "klâsiği”" nasıl aradığını ve bulduğunu, Batı'nın klâsiği ile bizim klâsiğimiz arasındaki duyuş ve ifade ediş farklarına ait dikkatlerini, ne zaman kaleme alındığına dair hiçbir gösterge ya da karineye sahip olmadığımız bu kısa yazıda paylaşır.

Yahya Kemal, 1906-1912 arasındaki şiir çalışmalarına dair diğer bir hatırasını, "T.B.M.M. Hususî" antetli bir kâğıda yazmıştır. Bundan, Meclis görevlerinden birisi zamanında kaleme alındığı sonucu çıkarılan yarım sayfa tutarındaki bu hatırada da Şair, Paris’teki şiir çalışmalarıyla Mallermé'yi gerçek mânâsında ilk kez ne zaman ve nasıl tadıp tanıyışını anlatır. Şiirin bir ses, nağme meselesi olduğunu daha ileriki metinlerinde defaatle vurgulayacak olan Yahya Kemal, "Mallarme'nin hüviyetine gözlerini”, Paris arkadaşı Romer de Kostal'ın sesinden dinlediğinde açtığını belirtir. Yarım kalmış olmasına hakikaten teessüf edilmesi lâzım gelen bu kısa metnin sonunda "o anahtarl eline aldıktan sonra dahi Mallarme'nin âleminin her tarafinı açamadı̆̆ını” itiraf eden Yahya Kemal, aslında Mallermé gibi bir sembolist değildir, olmayacaktır ama sembolizmin "ses ve musiki" tarafından çok beslenmiştir.

"Türk ve Fransız Edebiyatlarında Tenkit” başlığıly sunduğumuz diğer bir yazının 1927 'de, Varşova'da yazıldığına dair bir karinemiz vardır. Zira yazı "Beş sene evvel bir gün" diye başlamakta ve Yahya Kemal, biraz aşağıda da "Süleyman Nazif'le iyi ve sık sık görüştüğüm sıralardaydı; edebiyatımızın bu kuvvetli şahsiyeti Namık Kemal'e dair âteşîn bir nutuk yazıyordu" demektedir. Süleyman Nazif, Yahya Kemal'in de hazır bulunduğu bu konferans1, 12 Mart 1922 akşamı Dârülmuallimîn-i Âliye Salonunda vermiştir. (Samsakçı, 2011, s. 1-46) Bu yazıda da Yahya Kemal, Cercle D’orient'da karşılaştığı Osman Nizami Paşa ile Abdülhak Hâmid hakkında yazılmış bir yazı üzerine kısa bir diyaloğunu aktardıktan sonra Türkiye'de edebî tenkidin durumuyla Fransa'dakini karşılaştırır. Bu yazının asıl ağırlık noktası, bizde eleştiri yazılarının çoğu kez hayranlık sâikasıyla yazılmış olmaları ve bu yüzden okunmamalarıdır. 
Bu bölümde değerlendirilecek son yazı, doğrudan Abdülhâk Hâmid'le ilgilidir. Burada yayımladığımız parçadaki muhteva yani bu tanışma / ziyarete ait bazı küçük bilgiler, Yahya Kemal'in Nihad Sami Banarlı'ya anlattı̆ğ hatıralarında da karşımıza çıkmaktadır. Bu hatıraların “Şiirde Otuz Senem” başlıklı kısmında Yahya Kemal, Banarlı'ya hangi sene nerelerde kaldığını, nelerle meşgul ve kimlerle mülâki olduğunu sayarken 1906 yılı için şunları söyler:

“1906 Temmuz'unda Londra'ya gittim; Recins Park'a (Regents Park) yakin bir sokakta, bir Ingiliz ailesi yanında iki buçuk ay pansiyoner kaldım; yalnız geziyordum ve çok okuyordum. Shakespeare' in başlıca dramlarını, Montégut'nün tercümesinden biliyordum; orada Abdülhâk Hâmid'i bir-iki defa gördüm; çok iyi hüsn-i kabul gösterdi, lâkin şiir tarafima kayıtsı kaldı; ben de açılmak istemedim, hatta hiçbir parçamı kendisine göstermek lüzumunu hissetmedim." (Banarlı, 1997, s. 81-82)

Yine bu hatıralarda Yahya Kemal, o günlerde "yeni bir dil ve tarzda" bir Türk destanı yazmaya başladığını (ki bu destana ait bazı parçalar bilinmektedir), bunu başaramadığını ama yazmaya çalışırken "kendisine göre bir şiir lisanı bul"duğunu söylemektedir ki bu ifadeler, aşağıda tam metnini vereceğimiz küçük hatırat parçasıyla kısmen uyuşmaktadır. Fakat burada verdiğimiz metinde yukarıda zikredilen anekdotlardan çok daha ayrıntılı tasvirler ve ifadeler söz konusudur. Yine yarım kalan bu hatırada Yahya Kemal, Hâmid'in kaldığı evi, o yaşlarında Hâmid'i nasıl telâkki ettiğini ve Hâmid'den neler okuduğunu, salonunda O'nu bekleyişini, görüşmeyi; Abdullah Efendi diye bir zâtın sohbete dahlinden sonra konuşulanları ve yaşadığı hayâl kırıklığını, nihayet Hâmid'in 1906 yılında Londra'da nasıl yaşadığı ve insanlar tarafindan nasıl algılandığını anlatır.

Hâmid'i görmek maksatlı bu Londra seyahatinden, Yahya Kemal'in Paris arkadaşı Abdülhâk Şinasi Hisar da bahsetmektedir:

"Yahya Kemal, Paris’te eserlerini okumakla iktifa etmeyerek üstatları şahsen tanımayı da istemişti. Mahza nice şiirlerini ezber bildiği Abdülhâk Hâmid'i görmek için, 1906 senesi yazında Paris’ten Londra'ya gidip O’nu Piccadilly'de bir terzi dükkânının üstünde, dar bir merdivenle çıkılır küçük apartmanında ziyaret etmişti. "Üstünde pek şık elbiseler var. Fakat kendisi, bundan habersiz bir sadelik ve tabîilik içinde daha ziyade şık görünüyor!” diye” O’na artmış bir muhabbet ve hürmetle dönmüştü. Vachette Kahvehanesi'nin daha az kalabalık bulunduğu öğleüstü saatlerinde bize Hâmid'in hâlis şiir addettiği mısralarını ezberden okurdu.” (Hisar, 1959, s. 15)

Münevver Ayaşlı’nın “işittiklerine, gördüklerine, bildiklerine” göre de Yahya Kemal, 1906'da, o zamanların genç şairleri için “gaye insan” olan Abdülhâk Hamid'i ziyaret maksadıyla Londra’ya gitmiştir. Ayaşlı bu ziyarete ait hatıra ve anekdotları bizzat Yahya Kemal'den dinlediğini belirtir. Buna göre Yahya Kemal, hafta içi bir günde Hâmid'i kaldığı evde ziyaret etmiştir. "Yüksek İngiliz sosyetesini iyi bilen" ve bunlarla görüşen Hâmid "Pazar gününe kadar kalınız, beraberce bir yere gidelim" deyince de "kimbilir hangi Lord ya da Lady'nin malikânesine" gitmek üzere olduğunu düşünen Yahya Kemal için bu tecrübe tam bir hayâl 
kırıklığgidır. Zira gittikleri yer, Londra'nın sefil mahallelerinden birisinde bulunan bir halı deposu veya ardiyesidir ve kendilerini şık ve mükellef bir sofra değil, Şark usûlü bir çilingir sofrası beklemektedir. (Ayaş11, 1973, s. 68-70)

\section{Tarih - Siyaset - Siyasîler}

Yahya Kemal'in burada neşredeceğimiz metinleri arasında çoğunluğu, "tarih, siyaset ve siyasîler" hakkındaki yazıları oluşturmaktadır. Zaman zaman edebiyata da taalluk eden fakat daha çok tarih, siyaset ve tefekkür konularını ihtiva eden bu 14 yazıyı biz anlatılan konu veya şahsiyetin tarih içerisindeki yerine, diğer bir deyişle "konu kronolojisine" göre sıraladık.

“Legation de Turqie Madrid” antetli bir kâğıda yazıldığına göre Şair'in Madrid elçiliği zamanlarında yani 1929-1932 arasında yazıldığı anlaşılan ilk metin, Yahya Kemal'in 11 Haziran 1926 gününe ait bir hatırasıyla başlar. Fakat asıl metin, 18. asra, Prut, Ukrayna, Ukrayna'nın istiklâli, Rus ilerleyişi, Baltacı Mehmed Paşa gibi mesele ve şahsiyetlere dairdir. Şair, evvelâ Varşova elçiliği görevine giderken Bükreş’te iki gün kalışını, Bükreş’ten trenle yola çıkışını, trenin Prut üzerinden geçerkenki tefekkür, tahattur ve tahayyüllerini nakleder. Osmanlı tarihini asır asır ya da padişah padişah değil, sadrazam sadrazam bildiği belirtilen Yahya Kemal'in bu notlardaki tespit ve tahlilleri, Prut meselesinin, Osmanlı İmparatorluğu'nun Avrupa'daki hatta dünya siyasetindeki yeri konusunda nasıl bir kırılma noktası olduğunu vurgular mahiyettedir.

Arşivdeki iki belge Namık Kemal'le ilgilidir: Bunların ilki “Madrid'de bu güzel Mart akşamı, kalbim milliyetimizin hüsranlarıyla bir daha dolu olarak tek başıma düşünürken bu hayale kapıldım" cümlesiyle başlayan "Bir Tahayyül” başlıklı bir yazıdır. Diğeri başlıksızdır. Yahya Kemal'in Namık Kemal'i çok önemsediği, daima okuduğu bilinen bir gerçekse de O'nun Edebiyata Dair ya da Siyasî ve Edebî Portreler'inde doğrudan Namık Kemal'i konu alan bir yazısı bulunmamaktadır. Bununla beraber Edebiyata Dair'de, 21 Aralık 1940'ta yani Namık Kemal'in Doğumunun 100. yılında Ahmet Emin Yalman'ın Vatan gazetesi için Yahya Kemal'le yaptığı bir röportaj söz konusudur. (Beyatl1, 1997a, 276-283) Yahya Kemal, bu mülâkâtta Yalman'ın Namık Kemal hakkında sorduğu yerinde soruları samimiyetle cevaplar. "Bir Tahayyül”, aslında “fantezi” kabilinden bir yazıdır. Şair, muhayyilesinde Namık Kemal'in yalnız ruhunu olduğu gibi alıp "kafasını” Alman tarihçi Teramke kadar büyüterek bu iki ruh ve kafanın birleşiminden nasıl bir milliyetçilik zuhur edeceğini tahayyül eder. Bunun devamı niteliğinde olan diğer yazıda da Vatan Şairi'nin Türkçeye hediye ettiği "hürriyet, milliyet, vatan" kavramlarını ele alır.

Arşivdeki siyasî içerikli diğer bir yazı, intihar mı ettiği yoksa bir cinayete kurban mı gittiği konusunda hâlâ tartışmalar, spekülasyonlar yapılan Sultan Abdülaziz'e aittir. “Abdülaziz'in Hal'i” başlığıyla verdiğimiz ve “Abdülaziz'in hal’i, birbiri arkasından, kaza ve kaderin akıntısına benzeyen bir sürü hadiselere sebep olduğundan, o zamandan beri siyasî tarihimize meraklı olanları düşündürüp duruyor" cümlesiyle başlayan bu kısa yazıda Yahya Kemal, musahabesini, padişahın hal'ini "milliyet ve inkılâp" taraftarlarıyla "muhafazakâr ve saltanatçı" olanların nazariyelerini kıyaslamak ve çürütmek suretiyle yapar ve bu hadisenin arkasında 
başka sebeplerin olduğunu sezdirir. Yazı yarım kaldığı için, Yahya Kemal'in konu hakkındaki asıl yorumu tebarüz etmemiştir.

“Râgıb Efendi” başlıklı belgede Yahya Kemal, henüz Üsküp’te, 16 yaşlarında tanıdı̆̆g, kendileri gibi Leskofça muhacirlerinden olup Gilan'a yerleşen, Namık Kemal'in "şeyda" hayranlarından ve Jön Türk sempatizanlarından olan bir zâtı söz konusu eder. Bu kişi tek kelimeyle Yahya Kemal'i fikirlerin, ideolojilerin ve siyasetin âlemine sokmuştur. (Beyatlı, 1999, 59-65) Yahya Kemal bu portre türü yazının devamında, hakkında "Bu zavallı Leskofçalı genç, vazi' bir aileden doğarak oralarda metruk kalmasaydı muntazam bir tahsil görseydi şaşırıp milliyetimizden ayrllmasaydı bu devrin başlıca şahsiyetlerinden biri olabilirdi." dediği Halim Efendi' den de bahseder. Halim Efendi de Râgıb Efendi gibi Kosova Vilâyeti Polis Dairesi'nde çalışan ama yine arkadaşı gibi Meşrutiyet sonrasında silinip giden gençlerden birisidir.

Arşivdeki belgelerin büyük çoğunluğunu, Abdülhamid idaresi, Paris’teki Jön Türkler, Meşrutiyet'in ilânı ve ilk seneleri, İttihat ve Terakki iktidarı, Devletin 1. Dünya Savaşı'na girişi, "İlk Haber” başlıklı yazıda görüldüğü üzere de Bulgaristan cephesinin yarılmasıyla savaşın bitişinin İttihatçı hükümet tarafından nasıl değerlendirildiği hakkında yazılan yazı, hatıra, portre ve sohbetler teşkil etmektedir. "Dibace Kılıklı”, "Siyasî Hatıralarım”, "Tanıdı̆̆ım Genç Türkler”, “Ömer Naci” gibi başlıklar taşıyan, kimisi de başlıksız olan bu metinlerin de 1927-1931 arasında kaleme alındığı, çeşitli karineler sayesinde ileri sürülebilir. Bu yazılarda Yahya Kemal, derin bir seziş kudreti ve vukufla kavradığı, bazılarını Paris’te, bazılarını da 1912'deki dönüşünden sonra İstanbul'da tanıdığı önemli asker ve politikacıları anlatmış; dönemler, şahsiyetler ve iktidarlar arasında yaptığı mukayeselerle bir devrin panoramasını vermek istemiştir. Bu metinlerde Meşrutiyet'e takaddüm eden senelerde Jön Türk kadrosunu kimlerin oluşturduğu, kimin, hangi fikirde ve tabiatta olduğu, Meşrutiyet'in ilânında ve özellikle 1. Dünya Savaşı ve sonrasında, bu kişilerin hadiselerin neresinde ve hangi sâiklerle bulundukları alınmaktadır. İçerik kronolojisi bakımından Arşivdeki son metin, Yahya Kemal'in Madrid elçiliği sırasında kaleme aldığı kesin olan ve çok ciddî bir politik krizin içerisinde bulunan İspanya'ya dair meselelere, özellikle de Türkiye - İspanya münasebetlerine ait olanıdır. Bu belge, aslında Türk Hariciye Vekâleti’ne yazılmış bir rapor mahiyetindedir.

\section{SONUÇ}

1884-1958 yılları arasında yaşayan, çok küçük yaşlarından itibaren, vuku bulan askerî ve siyasî hadiselerin de tesiriyle fikirlerin ve mefhumların dünyasına giren Yahya Kemal'in eserleri ve bunların neşri, Yeni Türk Edebiyatı disiplini içerisinde daima tartışmaları barındıran bir mevzu olmuştur. Henüz hayatında bir mesele hâline gelen, Yahya Kemal'e tuhaf bir şöhret dahi kazandıran bu konu, Şair'in vefatı sonrası farklı bir boyut kazanmış, kimisi süreli yayınlarda çıkmış, kimisi de translitere ve tasnif edilip yayımlanmayı bekleyen bu yazılar, hatıralar, portreler hatta şiir parçalarıyla ilgili tartışmalar mahkeme salonlarına ve basına taşınmıştır. Neticede vârislerle anlaşan Yahya Kemal Enstitüsü, neşir faaliyetine başlamış ve Yahya Kemal'in eserleri büyük bir gayret ve feragatle peyderpey okuyucuyla buluşturulmuştur. Bununla beraber çeşitli 
araştırmac1lar, Yahya Kemal'in, günümüze kadarki süreçte çeşitli şekillerde ve yerlerde tespit ettikleri ve külliyatta yer almayan yazıları neşretmişlerdir. Bu çalışmada ise Yahya Kemal'in, İstanbul Şehir Üniversitesi tarafından erişime açılan Taha Toros Arşivi’nde yer alan ve daha önce Enstitü'nün neşretmekte olduğu külliyatta ya da başka herhangi bir yerde yayımlanmamış olan 18 adet hatıra, anı-portre ve musahabesi, bazı açıklayıcı notlarla birlikte ilim âleminin dikkat ve istifadesine sunulmuş olmaktadır.

Bu 18 yazı, Yahya Kemal'in hem Üsküp ve Paris yıllarına 1şık tutmakta; insan ve sanatkâr olarak şahsiyetini kimlerin, hangi eser ve ortamların tesiri altında bulduğuna dair değerli ipuçları sunmaktadır. Bu yazılar, Yahya Kemal'in ilk gençliğinde siyasî fikirlerle nasıl tanıştığını, Üsküp ve genel olarak Balkanlardaki siyasî atmosferi verdiği gibi, tarih ve siyaset tahsil etmek için Paris'e giden şairin, kendisini tatmin etmeyen mevcut şiir telâkkisi ve dili yerine yakalamak istediği estetiği kimlerde ve hangi eserlerde aradığı meselesine da açıklık kazandırır. Abdülhamid iktidarının bu son yıllarında Paris’te, hangi Jön Türk'ün hangi hizbe dâhil ve hangi fikre bağlı oldukları yanında bu kişilerin Meşrutiyet’ten önceki ve sonraki durumları da keskin bir dikkat ve gözlemlerle aktarılmaktadır. Namık Kemal Abdülhak Hamid, Tevfik Fikret, Cenab Şehabeddin gibi şairler de Yahya Kemal'in seziş ve ihata kudretiyle bu yazılarda yerlerini alırlar.

Baltacı Mehmed Paşa ve Prut Savaşı'na dair bir yazı ise, Bükreş üzerinden, orta elçi olarak atandığı Varşova'ya giderken Yahya Kemal'in yolculuk boyunca yaşadıklarını ve Türk-Rus münasebetlerine dair hatırladıklarını verir.

Dört uzun yılın sonunda birkaç imparatorluğun yıkılmasına sebep olan 1. Dünya Savaş1, savaş süresince Osmanlı asker, idareci ve münevverinin durumuna, yine İttifak Devletleri'nin savaşı kaybettiğine dair gelen "ilk haber"e ve buna gösterilen tepkilerle ilgili hatıra ise, bir devrin aktüalitesini vermesi bakımından bu yazı dizisinin en dikkat çekici satırlarından bazılarını içerir.

Burada neşredilen yazılarda bir kez daha görülecektir ki Yahya Kemal, tarihe, dile, edebiyata, musikiye ilgi duyduğu kadar resim ve mimarî gibi plâstik sanatlara da vâkıftır. Bir kültürü, kendisini teşkil eden bütün unsurlarıyla anlamak, kuşatmak isteyen her düşünür ve sanatkâr gibi Yahya Kemal, bu yazı, hatıra veya anekdotlarda Türk tarihinin, sanatının, edebiyatının pek çok meselesine, şahsiyetine dair bazılarında ufuk açıcı tespit, yorum ve değerlendirmeler yapar.

Finansal Destek: Yazar bu çalışma için finansal destek almamıştır.

\section{KAYNAKÇA}

Kolektif, (1984). Doğumunun 100. yllında Yahya Kemal Beyatl, Marmara Üniversitesi Yay.

Ayaşl1, M. (1973). İşittiklerim, gördüklerim, bildiklerim, İstanbul: Güryay Matbaacıllk

Banarl, N. S. (1997). Yahya Kemal' in hatıraları, İstanbul: İstanbul Fetih Cemiyeti Yay.

Beyatl1, Y. K. (1975). Tarih musahabeleri, İstanbul: İstanbul Fetih Cemiyeti Yahya Kemal Ens. Neşr.

Beyatlı, Y. K. (1986). Siyasî ve edebî portreler, İstanbul: İstanbul Fetih Cemiyeti Yahya Kemal Enstitüsü Yay. 
Beyatl1, Y. K. (1997). Mektuplar-makaleler, İstanbul: İstanbul Fetih Cemiyeti Yahya Kemal Enstitüsü Yay. Beyatl1, Y. K. (1997). Edebiyata dair, İstanbul: İstanbul Fetih Cemiyeti Yahya Kemal Enstitüsü Yay.

Beyatl1, Y. K. (1999). Çocukluğum, gençliğim, siyasî ve edebî htıralarım, İstanbul: İstanbul Fetih Cemiyeti Yahya Kemal Enstitüsü Yay.

Çoruk, A. Ş. (2018). Yahya Kemal'in kitaplarında yer almayan bazı yazıları, İstanbul Üniversitesi Edebiyat Fakültesi Türk Dili ve Edebiyatı Dergisi, 58 (2), s. 345-373.

Hisar, A. Ş. (1959). Yahya Kemal'e veda, İstanbul: Hilmi Kitabevi.

Samsakçı, M. (2008). Yahya Kemal Enstitüsü ve Müzesi, Yahya Kemal Beyatll, Kültür ve Turizm Bakanlığı Yay.

Samsakçı, M. (2008). Yahya Kemal'in eserlerinin kitap hâlinde ilk neşri meselesi ve bir mahkeme davası, Bir Medeniyeti Yorumlamak: Yahya Kemal Sempozyumu Bildirileri, İstanbul Fetih Cemiyeti Yahya Kemal Enstitüsü Yay.

Samsakçı, M. (2019). 1926 tarihli bir anket dolayısıyla Yahya Kemal'in edebiyatımız üzerine görüş ve yorumlar1, Türk Edebiyatı, 546, s. 40-44.

Samsakçı, M. (2019). Yahya Kemal ve İstanbul Üniversitesi, Kubbealtı Akademi Mecmuası, 189, s. 60-72. Süleyman Nazif. (2001). Namık Kemal, (Haz: Mehmet Samsakçı), İstanbul: Kitabevi Yay.

Toros, T. (1998). Türk Edebiyatından altı renkli portre, İstanbul: İsis Yayınc1lık.

Yetiş, K. (1998). Yahya Kemal I - Hayatı, İstanbul: İstanbul Fetih Cemiyeti Yahya Kemal Enstitüsü Yay., İstanbul, s. 204.

Yetiş, K. (1998). Yahya Kemal I Hayatı, İstanbul: İstanbul Fetih Cemiyeti Yahya Kemal Enstitüsü Yay., s. 200. 
EK:

METINLER

\section{YENI ŞİIRE DOĞRU - KLÂSİĞİ KEŞİF}

1908'e kadar şedit bir ihtirasla yalnız ve yalnız yeni bir şiirin ufuklarına doğru koşmuştum. Yakası açılmamış bir âlemi aramıştım, hatta yeni şekillerin yenilik olmadığını farz ederek şiirde yeni bir hava bulmaya heveslenmiştim. Bu ceht ve bu vecdimin sonunda yeni bir âlem bulmadım. Lâkin Tevfik Fikret ve Cenab Şehabeddin'in bütün bizim neslimizi içinde bulundurdukları daireden çıkmış oldum.

Aynı zamanda o kadar şedit bir yenilik ihtirasının aksülameline de uğradığımı söylemek istiyorum. O vakit, yani 1908-9 senelerinde Racine, Tasoy?, Horace ve Sofokles'i hararetle okuyordum. Yanıbaşımda bir Jean Moréas vardı. Harika nev'inden bir edebî zevke mâlik olan bu adam Yunan ve Fransız klâsiklerini en bigâne zâikalara tattırabiliyordu. Bahusus ki bir Iphigeinia yazarak eski “trajedi”nin bu makine ve sür'at zamanında aynen devam ettiği vehmini vermişti. Bu saydığım mütalaalardan ve Moréas'ın bu kaydettiğim tesirinden benim kafamda, bizim klâsiklerimizden Bâkî'yi, Nef'î'yi, Nâbî'yi, Nedîm'i iyi bir defa okumak ve anlamak temayülü uyandı. Bulvar Saint Germain üzerinde Elsine-i Şarkıye Mektebi Kütüphanesi'nde eski divanların iyi nüshaları vardı. Oraya gidip okumaya başladım. Horace'tan ve Racine'den Bâkî’ye ve Nâbî'ye geçiş, şüphesiz ki birbirine benzeyen iki bahçeye geçiş olmaktan uzaktı. Yalnız benzedikleri bir nokta vardı: Bu nokta, her iki tarafın da birer milletin asırlar zarfinda, kademe kademe hâsıl olmuş olgunluğu idi. Yanılmıyorsam "klâsik" de bu demektir. Fransız terbiyesiyle Lâtin güzelliğinin olgunluğunu hissetmeye hazırlanmış olduğumdan, Osmanlı şiirinde Şark güzelliğinin olgunluğunu daha kolay hissetmeye başladım. Lâkin nüfuzumun derecesi bu kadardı. Osmanlı'nın arkasında kalan Acemi ve Arabı bilmiyordum. Hatta Osmanlı lisanı denilen kadim yazı lehçelerimizi iyi bilmek ihtiyacını idrak ediyordum. Kısa yoldan yürümek arzusuyla mütalaalarımı şiirden nesre çevirdim; eski tarihlerimizi okumaya koyuldum. Meselâ Naimâ'dan uzun bir cümle alıyordum. Bu cümlenin her kelimesini yeni Türkçede öğreniyordum. Sonra bütün cümleyi yeni Türkçeye "tercüme!” ediyordum. O eski lisanın anlayış ve söyleyiş farklarını temyiz etmeye çalışıyordum. Lâkin bir müddet sonra gördüm ki bu yol, zannettiğimden daha uzundur. Zira eski lisanı vukufla bilmek kâfi değildir, Kadim bir Osmanlı'nın, meselâ Nâbi'nin kafasının kâinatı nasıldı? O'nun zâikası nasıldı? O'nun kalbi nasıldı? Bunları ihata etmek lüzumu vardı. İşte o zaman, mesela bir Moréas'ın o emsalsiz edebî terbiyesine büsbütün hayran oldum. Çünkü $\mathrm{O}$, hiç uydurma bir tarafı olmaksızın, aynen bir Sofokles gibi hissederek kadim trajediyi vücuda getirebiliyordu. Sırası gelmişken bir bahsi de işaret edeyim: Eski şairlerimizi okurken, onların yalnız iştirak ettiğimiz güzel tarafları bize onlarla çok yek-dil olduğumuza dair bir vehim veriyor. Hâlbuki yalnız zâika tarafını mütalaa etsek, onların nice zevklerine asla iştirak edemeyiz. Meselâ ben, eski şiirde çok tekerrür eden "şeker", "sükkerîn” sıfatından tiksinti hissediyorum. "Sükkerîn tebessüm, sükkerîn tekellüm, şeker-lebler, şeker lebleri emmek” benim zâikama ait değildir. Eski şiirde her zaman, her şair 
tarafından tekrar ediledurmuş, hatta çok kere gazellere redif olmuş olan "hat", Tanzimat'tan sonra yetişmiş olan bizlere çok başka bir zevk gibi geliyor. Yine meselâ bu nev'i'den "tûtî" teşbihi, kıymetli bir teşbih midir? hissini veriyor. Hâsılı bu misallerle sahifeler doldurmak mümkündür. Eskilerin nice çiçekleri, nice râyihaları, nice kumaşları - yabancı demeyeyim fakat - bize aykırı görünüyor.

Yine şahsî bir müşahedemi söyleyeceğim: Kadim Yunan'ın ve Acem'in insan güzelliğine dair şiirlerine verdikleri telâkkileri, heykeltraşîlerine ve minyatürlerine mutabık gördüm. İlyada' da Homeros'un tasvir ettiği ilahelerden birini heykel hâlinde bir müzede evvelce görmemiş olsaydım, yine mutabık görürdüm. Acem güzellerini de eski İran minyatürlerinde tıpkı öyle seyrettim. Fakat Homeros'un ${ }^{6}$ tarif ettiği kahramanları muharebe hâlinde o zamandan kalma vazolar üzerinde görünce şaşırdım. "Acaba bu heybetli kahramanlar, şu bücür insanlar mıdı?” dedim. Firdevsî'nin tasvir ettiği Efrasyab'1, Rüstem'i, ..... da daha mehib tasavvur ediyordum. Eski Şehname'lerin minyatürlerinde gönlümce benimseyemedim; bu Rüstemler bana pek cılız göründüler. Bu fark nereden geliyor? Şüphesiz benim gördüğüm şehnameyi benden evvel Nâbî Efendi yahut da muasırları okumuştular ve o resimleri başka gözlerle ve istiğrakla seyretmiştiler.

\section{FRANSA YILLARINDA ŞİIR...}

1906-1912 senelerinde Paris'in sanat âleminde yaşayan her genç gibi ben de Mallarmé'nin şiirlerini kitaplarda ve mecmualarda okumuştum. Hatta o şiirleri, inşad edilirken dinlemiştim. Mallarmé'nin hayatını Besançon Lisesi'nden Roma Sokağı'ndaki musahabelerine kadar iyi öğrenmiştim; dostlarını, hayranlarını, tilmizlerini ezberden bilirdim. Şiire dair görüşlerini ise kılı kırk yararcasına tetkik etmiştim. Bütün bu vukufuma rağmen O’nu asla anlamadığımı bir gün anladım. O gün O'nu bir hayranının ağzından, ilk anladığım gündü. Evet, o gün gaflet uykusundan uyanmış ve gözlerimi O'nun hüviyetine açmıştım. Kulaklarıma ilk defa O'nun şiirinin musikisi aksetmişti.

Arkadaşım ki Romer de Kostal Mallarmé'nin “Kuğu” şiirini hakikî kıymeti ile hayaline nakşettiği gibi okurken benim hayalime de nakşetmişti. $\mathrm{O}$ anda, Mallarmé lisanının nağme dantelasını gözle görür ve elle tutulur gibi ayan beyan duydum. Arkadaşım O'nun âlemine girebilmek için elime bir altın anahtar vermiş oldu.

Lâkin o anahtarı elime aldıktan sonra yine Mallarmé'nin âleminin her tarafını açamadım. O’nun küçücük şiir mecmuasında sayılı manzumelerinin birinden birine geçemiyordum; hatta aynı manzumenin iki mısraını anlıyor, onu takip edenleri anlayamıyordum. Beşeriyete küçücük bir şiir.... ${ }^{8}$

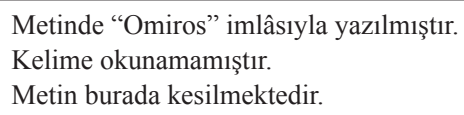




\section{TÜRK VE FRANSIZ EDEBIYYATLARINDA TENKITT}

Beş sene evvel bir gün, Cercle D’orient'ın kıraat salonunda sâbık sefir-i kebirlerimizden Osman Nizami Paşa'ya tesadüf ettim. Ekseriyetle sakin olan bu salonun bir köşesinde öteden beriden konuşurken bu eski sefirimizin gözü, yanımızda duran bir masa üzerinde, bir edebî mecmuaya ve o mecmuanın açılmış bir sahifesinde görünen "Abdülhâk Hâmid ve Eseri” unvanlı bir yazıya ilişti ve bana dedi ki: "Meselâ ben bu yazıyı birkaç günden beri gördüm ve okumaya lüzum görmedim, okuyamam da eminim ki methediyor!" dedi. Edebî ihtiraslarla alâkası olmayan, yaşını-başını almış bir güzidemizin bizdeki edebî makaleler hakkında böyle yerleşmiş bir fikri vardı. Ben de O'nun zannına baştan iştirak ediyordum. Emindim ki o makale, Abdülhâk Hâmid Bey'in dehasını kırk seneden beri işittiğimiz hayranlıkla dolu ayrı bir yazıydı. Ben edebî cereyanlarımıza alâkadar olduğum hâlde bu gibi yazıların kaçını ve kaçını okumaya lüzum görmediğimi hatırladım. Cenab Şehabeddin gibi imzası nerede olursa olsun cezbedici bir kudrete mâlik olan bir nâsirimiz Abdülhâk Hâmid hakkında bir kitap neşretmişti. Bu kitabın sayfalarına öteden beriden göz gezdirmiş lâkin bir Frenk kitabını okur gibi; iptidadan intihaya kadar okuyamamıştım. Diğer bir ihmalimi bu münasebetle ifşa edeceğim: Süleyman Nazif'le iyi ve sık sık görüştüğüm sıralardaydı; edebiyatımızın bu kuvvetli şahsiyeti Namık Kemal'e dair âteşîn bir nutuk yazıyordu. Namık Kemal'in hayatını ve eserini öğrenmeye öteden beri heveskârım. O'nu tanımışları âdeta zorlayarak hakkında birkaç müşahede elde etmeye uğraştığım olmuştu. Lâkin Nazif kadar şahsen sevdiğim bir insanın o nutkunu iptidadan intihaya okumak neşvesini kendimde bulamamıştım. Tevfik Fikret hakkındaki nutuklardan ve yıldönümü makalelerinden bahsetmeyeyim: Çünkü satırlarına gözüm bile ilişmezdi.

Benim bu hâlet-i ruhiyemde yalnız bir Osman Nizami Paşa mı gösterilebilir? Kaçımız ve kaçımız belki memnuniyetsiz bu hâlet-i ruhiyede değil miyiz? Acaba hep Namık Kemal, Abdülhâk Hâmid ve Fikret gibi bellibaşlı şahsiyetlerimize mi lâkaydız? Yoksa bizdeki tenkit tarzına mı?

Mukayese zeminine girerken; boğulmamak için en fazla aşina olduğumuz bir edebiyatta bu zikri geçen üç edibimizin muasırları hakkındaki alâkayı düşünüyorum. Namık Kemal, Fransa' da Paul Verlaine'in, Henry Rochford'un ve Anatole France'ın muasırıydı. Bu üç Fransız şahsiyeti hakkında hayranlarının yazmış oldukları makaleler, tenkitler, hatıralar ve kitaplar, Namık Kemal'in hakkında bizde hayranları tarafından yazılmış yazılara kemiyetçe nispet kabul etmez bir derecede fazladır; yani bu adamların isimleri daha fazla tekerrür etmiş ve kabak tadı vermek şöyle dursun daima alâkayla okunmuştur, demek istiyorum. Aynı zamanda bu nevi şahsiyetler hakkında iyi yazı yazanlar daima en şedit hayranları olduğunu kaydetmeyi faydalı göremiyorum. Bizde Namık Kemal'in ilk ve en şedit hayranlarından biri Ebuzziya Tevfik'ti. Ebuzziya, Namık Kemal'i yakından tanımış, O’nunla düşmüş-kalkmış ve O'nun hakkında en ziyade salahiyetle bahsedecek bir insandı. Heyhât ki u hayranın Kemal hakkındaki nesirleri, "harika" ve "bârika"lar gibi kâr-1 âlem tavsiflerle dolu, tadından yenmez bir sürü kasidelerdir. Paul Verlaine'in aynı şiddetle hayran bir arkadaşı olan Gustave La Rouge'un Verlaine hakkında bir kitabı vardır. "Bu kitabı bir hayran yazmış, binaenaleyh zaten medihle doludur, okunmaya değmez" diye elinden atabilecek bir kārie tesadüf edilebilinir mi? Bilakis Gustave La Rouge gibi Verlaine'i yakından tanımış bir adamın kitabıdır" diye ilk satırından son satırına kadar 
ihtirasla okuyan kāriler Verlaine'i bir defa daha benimserler. Keza Henry Rochford'un hayranları, bu zehirli heccav hakkında $\mathrm{O}$ yaşarken de öldükten sonra da binlerce tenkid, tasvir ve hatıra yazdılar. Hem de Henry Rochford gündelik bir heccavdı. Yani hivciyesinin tesirâtı ve değeri, vak'aların hararetine göre günü gününe idi; devamlı ve bâkî bir eser sahibi değildi. Anatole France hakkındaki tetebbular daha geniş ve yüksek bir kırattadırlar; hepsi derin alâkalar uyandırmıştır. Abdülhâk Hâmid Bey’in muasırları olan Jean Moréas, Henri Doreye? Jules La Forgue, Mouris Barres, ${ }^{9}$

\section{ABDÜLHÂK HÂMİD}

1906 Temmuz’unda Londra’ya gitmiştim. Bu seyahatte özlediğim şeylerden biri de orada Abdülhâk Hâmid'i görmekti.

Bir iki gün sonra Abdülhâk Hâmid'i Piccadilly Caddesi üzerinde ikamet ettiği küçük evde ziyaret ettim. Bu bina ne kadar garipti! O muazzam caddenin siyah granit külçelerinden kurulmuş hissini veren büyük müheykel ve yüksek yapıları arasına sıkışmış ahşap nev'inden? alelâde bir evceğizdi. Sokak kapısı açıldığg vakit, önüme dimdik, dar ve tahta bir merdiven çıkıyordu. O kadar ki yanlış bir kapı çaldığımdan şüphelendim; Londra saltanat-ı seniyyesi sefaret-i kübrâsının müsteşarı olan bir zat burada oturamazdı. Fakat merdiveni tırmanıp çıktım. Önüme alelâde giyinmiş bir hizmetçi kadın çıktı: "Abdülhâk Hâmid Bey buradadır, salonda birkaç dakika bekler misiniz?” dedi. Dar bir kuluradan çevrilince, küçük bir kapıdan küçük bir salona girdim. Bu salon Piccadilly Caddesi'nin durup dinlenmek bilmeyen gürültüsü üzerinde idi. Döşemesi alelâdeydi. Bir şömine üzerinde Namık Kemal'in fotoğrafisi, bir masa üzerinde Tevfik Fikret'in mücelled "Rübâb-1 Şikeste"si Hâmid Bey'in oturduğu yer olduğu anlaşılan köşe koltuğunun yanında da bir satranç kutusu duruyordu. Kafam Servet-i Fünun'da "Sahâif-i Bedia” sernamesiyle okumuş olduğum Finten'in manzaralarıyla dolu idi. Müteheyyiçtim. Abdülhâk Hâmid'i Londra' da görecek olan talihli Türk gençlerinden biri idim.

Biraz sonra gülümseyerek Abdülhâk Hâmid geldi. Köşedeki mutad yerine oturdu. Konuşmaya başladık. Konuşurken caddeden tiz bir kaval sesi geliyordu. Bu sesten Abdülhâk Hâmid, muazzeb görünüyordu. Pencereyi kapadı. Gün ortasında o dumanlı sanati payitahtının caddesinden gelen bu kaval sesi, gayr-1 muntazır bir şey olmakla beraber Abdülhak Hâmid, dünyada en sevdiği şeylerden birinin kaval olduğunu ilâve etti. Bu fikir bana fârikalı göründü. Paris'e, tahsile, aileme, şuna-buna dâir alelâde suallerden sonra kendisine bir tevcihnamesini getirmiş olduğum Sâmipaşazâde Sezai Bey'in sıhhatini, Paris’te nasıl yaşadığını sordu. Fakat sözlerinden Sezai Bey’e karşı teveccühkâr olmadığı, Ahmed Rıza Bey’e karşı ise tezyifkâr olduğu seziliyordu. $\mathrm{Bu}$ his ayrılıklarına dair Paris’ten beri kulak dolgunluğum vardı. Ve şaşmıyordum. Nihayet söz şiire intikal etti. Tevfik Fikret’ten, Fâik Âli'den, gençlere karşı takdirkâr bir şive istimal eder gibi bahis açtı. Fakat Edebiyat-1 Cedideye fazla bir hayranlığı olmadığı görülüyordu. Sonra sözü Namık Kemal'e çevirdi. O’nu, yegâne üstadı gibi, huşû ile göklere çıkardı. O’nu gençliğinde Çamlıca'da ve sonra Mehterhane'de, mahpus iken ziyaret ettiğini söyledi.

9 Metin burada kesilmektedir. 
Biz konuşurken içeriye bir ziyaretçi girdi. Çok muhabbetkârâne kabul edişinden, Hâmid Bey'in yakını ve fazla sevdiği bir dostu olduğu anlaşılıyordu. Abdullah Efendi olduğunu öğrendiğim bu zat, o gün, orada Ahmed Rıza’ya, Jön Türkler'e, çok saldırışlı konuşusuyla benim üzerimde iyi bir tesir bırakmadı. Mamafih Abdullah Efendi'nin şöhretini, ehemmiyetini, vaziyetini de işitmiştim. Bütün dikkatim Abdülhâk Hâmid'de idi. Fakat Abdullah Efendi geldikten sonra Abdülhâk Hâmid Bey, beni unuttu. Abdullah Efendi'nin heccâvâne hücumlarından telezzüz eder bir tavır aldı. İkisinin de beni toy tavrı, her .... genç gibi kafasını Jön Türkler'e kaptırmış, onların kıymetsizliğinden bî-haber bir mübtedî saydıkları ikide birde Ahmed Rıza Bey'e dair irad ettikleri müstehziyâne suallerden kaba saba anlaşılıyordu. Fakat ben de o zaman, 1906'da Ahmed Rıza Bey'e hiç hayran değildim, Jön Türklük’ten ise bezmiştim. Büyük bir mikyasta şiir ile meşguldüm. Az çok Byron’u, Shakespeare'i, Michelet'yi Vigni’yi, epeyce iyi de Hugo'nun “Asırların Masalı”nı anlıyordum. "Flaubert”i anlayarak okuyordum. Verlaine ise ezberimdeydi. Mamafih zevkim o yaşta daha ziyade romantiklere mütemayildi. Onların tesiriyle de Abdülhak Hâmid Beyi yalnız "Finten şairi” olarak büyük görüyordum.

Abdülhak Hâmid, beni fazla ihmal ettiğinden küçük kafamın o andaki kâinatına ehemmiyet vermiyordu. O gün en büyük emellerimden biri, kendisine Fikret tarzından tamamıyla ayrı ve yepyeni addettiğim bir manzumemi okumaktı. Bu manzume, Avrupa’ya doğru ilk akınlarımızdan mülhem bir mevzudaydı. Fakat lisanca Türkçeliğe meyyâl, âhenkçe dolu ve sert, tasvirce Hugo'nun “Asırların Masalı”ından, Flaubert'in “Salambö”sünden müteessir fakat Türkçede mevcut şiire göre yakası açılmamış gibiydi. Fakat dediğim gibi Abdülhâk Hâmid'in bana karşı lâkaytlığı bârizdi. Bu şiiri okumak isterdim. Kendisinden o gün öyle ayrıldım. Gayr-i şuurî olarak inkisâr-1 hayale uğramıştım. Mamafih Finten'e olan hayranlığım kendisine karşı perestişkârlığımı zaafa uğratmaktan uzak bulunduruyordu. Londra'da üç ay kadar kaldım. Hâmid'i birkaç defa daha gördüm. Orada ülfet ettiğim Türkler, ekseriya Hâmid Bey’den, hayatından, meşrebinden bahsederlerdi Verdikleri malumâta göre Hâmid Bey daima para derdi, kadın lakırdısı ile adını geçiriyordu. Gündüzleri lüks sigara satan bir Rum dükkânında sohbetlerle eğleniyor; akşamları bir lokantaya gidiyor içmeye başlıyor, çok zaman sabaha kadar mest bir hâlde kalıyor, hâsılı lâübâli ve basit bir ömür sürüyordu. Para dertleri ise Londra'da herkesin dilinde idi. Hükümetin o zaman kendisine verdiği müsteşarlık maaşı 150 altındı. Hâmid Bey'in bundan maada Abdülhamid'den ayrıca, âtıfet nâmıyla bazı meblağlar aldığı, gizli kapalı bir şey değildi. Hatta bu hâlden müteessir olan Recâizâde Ekrem Bey, İstanbul'da Abdülhâk Hâmid Bey’in padişaha meşkûk mektuplar gönderdiğini iddia ettiği ve Sultan Abdülhamid gibi bir ifrite böyle bir hizmetin ne müstekreh olduğunu söylediği rivayet olunuyordu. Hâmid Bey, Ekrem Bey'in kullandığı bu ifrit sıfatından mülhem olarak Ekrem Bey’e bir mektup yazmış ve

\section{Ifritlerin de kalbi vardır}

Kalbinin tariki vardır

demiş olduğunu Hüseyin Siret söylüyordu. Bu fikra doğruya benziyordu. Çünkü o beyit hakikaten Hâmidâne ve Hâmid'indi. Bütün bu rivayetler... ${ }^{10}$

10 Metin burada kesilmektedir. 


\section{UKRAYNA ve BALTACI MEHMED PAŞA}

11 Haziran 1926. Lehistan’a gideceğim gündü. Şimal Ekspresi, akşamüstü kalkıyordu. Bükreş elçiliğinin erkânı, Sefir Hüseyin Râgıb, Ataşemiliter Hayri Bey, Başkâtip Kemal Aziz ve diğerleri ile gara geldik. Öteden beri dostum olan Râgıb, Bükreş’te kaldığım iki gün zarfında bütün kalbi ile asil bir misafirperverlik göstermişti. Miralay Hayri Bey’le Kemal Aziz'le ise orada tanıştım. Bu güzide insanlar, yiyecek ve içeceğe müteallik hediyeler getirmişlerdi. Mutat vedalarla ayrildık.

Tren, kömür ve çamur içinde kapkara bir güzergâhtan çıktı. Çıkmasıyla beraber zaten gece de oldu. Ertesi sabah Leh toprağında uyanmak üzere yattım fakat gece yarısından sonra kapıyı zorlarcasına vurarak, elleri fenerli birkaç üniformalı tarafından uyandırıldım. Romanya'nın maruf olan idare rezaletlerinden bir levhayı görmem mukaddermiş. Millî lisanlarıyla hitap eden bu memur efendilerin söylemek istediklerini yataklı vagon kontrolörü sözde bî-tarafâne bir vaziyette nakletti:

Mösyö, son feyezandan sonra tren, mutad olan hattan geçemediğinden bu hattın yanında, inşaatı biten diğer bir hattan geçiyoruz fakat bu hattan geçmek müsaadesi hakkında kumpanya ile hükümet henüz itilaf edemediler. Bunun için şirket, geçmek hakkını yolculardan istîfâ ediyor! Kendi hissenize beş yüz leva vereceksiniz.

Hayretle baktım. Kontrolör ilave etti: Biz bundan mesul değiliz ve paranın alınmasına karışmamamızı kumpanya emretti. Fakat yolculardan bu parayı almadıkça trenin kalkması mümkün değildir. Diğer yolcular da veriyorlar.

Paranın mutlaka istîfa edileceği hâlden belli idi.

İnat etmedim fakat inat edenlerin, bağırıp çığıranların sükût etmesine kadar bir saat kadar geciktik. Tren hele kalktı. Kontrolör geldi; kendi Beyaz Ruslardanmış. Rumenlerin idare rezaletlerinden, irtişa ve irtikâplarından, Avrupa'nın hiçbir yerinde görülmeyen hayâsızlıklarından bâhis bir konferans verdi. Meselâ kuttâ'-1 tarika bâc verir gibi verdiğimiz bu garip verginin yolculardan her gece alınacağını şirketin ültimatom kılıklı hükümete haber verdiğini, mamafih yine jandarma ve polisin bu verginin tahsilinde hakikatte şirkete yardım ettiklerini yana yakıla anlattı. Kontrole sordum: "Şirket ecnebi midir?" Birdenbire yerinden firladı. "Mösyö, ecnebi olur mu? Ecnebî şirket olsa burada bu akşam kendi soyulurdu. Hâlis Rumen olduğunu haydutluğundan anlamak kolaydır" dedi.

Şafak hudutta söküldü. O kadar asır zarfında ordularımızın, tuğlarımızın, bayraklarımızın, atlarımızın, börk, üsküf, destar ve tolgalarımızın geçtiğini görmüş olan bir mıntıkadaydık. Önce Lehlerle sonra Ruslarla o şedit çarpışmalarımız bu sahada olmuştu. Başım hayaletlerle doluydu. Tarihimizi bilmekte bile garbî Avrupa'nın tesiri altında kaldığımızdan daha ziyade Viyana üzerine yürüyüşümüzü tahayyül ederiz. Avrupa’nın üzerine atılışımızın gerçi bir yolu o idi. Fakat ikinci yolu burasıydı. "Hatta burası millî mukadderatımız üzerinde ötekinden daha 
müessir oldu demek" doğrudur. Bu toprağa basarken bin türlü tefelsüf arasında bilhassa biri dimağıma müstevli oluyor. Evet, biri yani Fazıl Ahmed Paşa’nın tasarladığı Ukrayna Beyliği! Ah bu hayal tahakkuk edebilseydi Tevfik Fikret'in tabiriyle "misli asırlara geçmemiş bir hayr" olurdu. O kadar muazzam bir hadiseydi. Ukrayna Beyliği teessüs edebilseydi Viyana bozgunundan beri ettiğimizi on üç Moskof seferini etmemiş olurduk! Rus Çarlığı şimalde kalırdı ve biz ona hiç değilse Fransa'ya kaldığımız kadar uzak bir devlet kalırdık. Ukrayna Beyliği teessüs etseydi o da şüphesiz bir müddet sonra kuvvetlenir, bize karşı istiklâlini ilân ederdi hatta ileriye giderek Kırım'a sataşırdı, belki de bizim esaslı bir müdafaa hattı saydığımız Boğdan'a da göz dikerdi. Fakat bu belâlar, ötekinin yanında çok ehven kalırdı. Zira müstakil bir Ukrayna, komşuları ile Moskof'tan ve Lehli'den vakit bularak, bize karşı Rus Çarlığı gibi o hesaplı ve kitaplı müthiş seferleri açamazdı. Diğer bir nokta da var: Ukrayna ne kadar kuvvetli olsa, Bulgarlar, Sırplar ve Ruslar üzerinde hâmilik edecek kadar, onları Slavlık cereyanıyla kaynatacak kadar uzun boylu işlere girişemezdi. Ukrayna müstakil olsaydı Rusya ile Türklük arasında bir siyasî muvazene teessüs ederdi, Lehistan taksim olunmaz, İsveç silinmez, Rusya'nın dünya istilâsı hırsına karşı birer murakıp kalırlardı. Ukrayna müstakil olsaydı Rusya'nın bize karşı en fazla saldırganlığı Kafkasya cihetinden vâki olurdu fakat bu cepheden onunla harp, Balkan cephesine nispetle devede kulak kabilindendi. Rusluğun bu cihetten Anadolu'ya sarkmasının henüz vakti gelmediğini 1877 ve bilhassa Harb-i Umumî seferleri iyi gösterdi. Hem yalnız bu cepheden biz kendimizi iyi müdafaa ederdik. Çünkü Kafkasya Balkan gibi Slavlarla, Müslümanlarla meskûndu. Ukrayna müstakil olsaydı, tahmin olunacak tebeddüllerin zikri uzun sürer fakat bir Türk sıfatıyla ilk hatırıma gelen mülâhazaya avdet ediyorum: Rusya ile Viyana bozgunundan beri o on üç seferimiz olmazd1. Ah bu seferler, bizde tasvir edilmediklerinden, bütün neticeleriyle idrak olunmuyorlar. Anadolu'da her köyün sefaleti, sâniyen vatan yollarına düşen o koskoca kavim, Rumeli halkının eriyip mahvoluşu, bugün her Türkün perişanlığı, denilebilir ki bu seferler yüzündendir. Roma'nın Kartaca'ya açtığı harpler, bize Rusluğun açtığı bu müthiş silsilesi yanında bir facia mı sayılabilir? Yanlış sayılmayacak bir görüşle diyebiliriz ki Türklüğün asıl kuvvetini ölçmek için bir miyar aranırsa, ilk ordularımızın Avrupa'ya atılışından ziyade, son üç asır zarfında Rus karşısında mağlûbâne, mütehevvirâne, mezbuhâne, nasıl denilirse denilsin fakat herhâlde mahvolmayarak gösterdiğimiz mukavemet, miyar sayılır.

Evet, "Ukrayna müstakil olsaydı!” hayali bu toprak karşısında fikri sarıyor. Fazıl Ahmed Paşa'ya Hetman Doroşanko'nun gönderdiği o mektup, o mektubu aldıktan sonra Ukrayna Beyliği'ni tesis etmeye kalkışması muazzam bir projeydi. Bu proje, Fazıl Ahmed Paşa'nın Lehlere ve Moskoflara karşı o kanlı son seferleri intâc etti. Osmanlı güneşi batarken, Rusya içerilerine doğru tuğlarımızın yürüdügünü gördü. Fakat hem Ukrayna hem de Rusya emsalsiz bir eser olan bu projenin Viyana önünden itibaren ..... ${ }^{11}$ gördüler. Zira Jan Sobieski’nin intikam hisleri işte bu seferlerden kalma idi. Bu, böyle olmakla beraber projenin doğru olmasını nehyedemez. Nasıl nehyedebilir ki bugün, bu saatte bile Ukrayna istiklâli, Avrupa'nın en

11 Kelime okunamamıştır. 
mühim cereyanlarından ve ideallerinden biridir. Fazıl Ahmed Paşa, gerek çocukluk müddeti ${ }^{12}$ gerek de Kara Mustafa Paşa'nın o vakit kapıldıkları iki ideal; biri Doroşanko’nun mukavemeti diğeri de Macar Kralı Tökeli'nin Avusturya'yı imha teklifi, ikisi de hiç boş değildiler. Bu iki proje ile Rus Çarlığı ve Habsburg Çasarlığı, sonraları hem bizim hem de Lehli milletlerin başında oynadıkları facialardan men olunmuş olurlardı. Heyhât ki iki proje de aksine, şeametler doğurdu. Elim neticesi(ni) fena ödedik. Michelet gibi: "Tarih, mukadderattır" mı demeli? Tahakkuk edememiş sağlam ideallerin karşısında zaten tahakkuk edemedikleri gibi böyle bir burhan varken müddea ispatı fazladır.

Tren hududu geçti. Sabah güneşi, temiz bir yaz manzarası vücuda getiriyordu. Prut üzerinden geçiyordu. "Prut", zarurî olarak bir Türk'e Baltacı Mehmed Paşa'yı hatırlatıyor. Her nedense bu gâlibâne seferimiz, herkesin kafasına yerleşmiş olan maruf muhakemeyle beraber klâsik sayılır. Rusya'yı o defa Deli Petro ile beraber bataklıklara gömebilirken Sadrazam'ın düşmandan para alması Çariçeyle visalde bulunması yüzünden serbest bıraktığımızdan, herkes iki asırdan beri dilden dile taşıyıp duruyor. Baltacı Mehmed Paşa'nın düşmanlarının, halis saray entrikası cinsinden olan bu rivayetleri, tabiî âmiyâne anlayışa pek uygun olduklarından, bâkî kaldı. Zavallı Prut galibi, bu türrehât yüzünden başını vermekle kalmadı, nâmını da asırlarca kirletti. İyi düşünen bir insana yek-nazarda garip görünür ki biraz önce bahsettiğimiz Ukrayna Beyliği hakikaten Rusya'yı bir ejderha olmaktan men edecek kırattayken Türkiye'de kimsenin dilinde gezmez fakat bu Baltacı Mehmed Paşa efsanesi zebanzeddir. Fakat bu tezat, hadd-i zâtında garip midir? Bu ikinci bahis büyük bir tefekküre ihtiyaç hissettirmez bir temâşâ şeklindedir, avam kafası böyle bir manzarayı çabuk görür. "Bataklığa atmak kābil iken atılmamış bir hükümdarın ve ordusunun bilâhare belasını da çeker" hükmünü kolay verir. O vakit Baltacı Mehmed Paşa'yı itham edenlerin başında İsveç Kralı Şarl ve Kırım Hanı Giray gibi, saray entrikasının tesiri altında bulunmayan ve hükümlerini kendi görüşlerine göre veren iki mühim adam vardı. On ikinci Şarl'ın müsellem olan dehasına hiçbir diyecek yoksa da kendi işte böyle hudutsuz ifratları yüzünden bize, Bender'e kadar misafir gelmişti. Kırım Hanının ithamı ise şüphesiz yakın ve hakikî tecrübelere müstenitti. Ancak bu Han'dan yüz kırk sene evvel, diğer bir Kırım Hanı olan Mehmed Giray, Ruslara karşı emsalsiz bir muzafferiyet kazanmış ve o zamana kadar bir muharebe meydanında misli sebkat etmemiş bir katliam icra etmiş, yani üçyüz elli bin Moskofu dana boğazlar gibi boğazlamış ve Rusya'nın bittiğine kanaat hâsıl etmişti. Düşman milletlerin bitmesini daima imha siyasetinden ummak sadedilliktir. Rusya, o zamanki mağlubiyetinden mahvolmadı. Fakat 1709 'da Prut bataklıklarında, Deli Petro’yu da kaybetse bilhassa kaybolmazdı. Nitekim Deli Petro'nun ölümünden sonra eseri şedit bir irticaa uğradı. Fakat Rusya yine dirildi. Bunun için Kırım Hanı'nın ithamı da abesti. Bahusus ki Baltacı Mehmed Paşa'ya isnat olunacak yegâne hata Çarı ve ordusunu bataklıklara gömmemekten ibaretti. Fakat sulh itibariyle bu vezire diyecek yoktur. İmzaladığ 1 sulhnamede Viyana bozgununun bu cepheye taalluk eden en esaslı zararlarını tazmin ettirmiş ve Karadeniz'i tekrar bir Türk gölü hâline getirmişti. Kimbilir, O’nun da söyleyeceği ve söylemekten korktuğu hakikatler vardı. Viyana'dan beri muttasıl kaçmış ve lüzumlu-lüzumsuz çadırları serdârân başına

12 Aslî metinde kelimenin üzeri çizilmiştir. Bu yüzden yeni yazıya aktarımda şüphe ve tereddüt söz konusudur. 
yığmış, düşmandan yılmış bir orduyla harp ediyordu. Karlofça'dan beri de muzafferiyet ilk defa yüzümüze gülüyordu. Bu galebeyi tadında bırakmayı kim bilir ne gibi rüyetlerle münasip gördü, Evet, O’nun Prut önünde, o günlerde gördüğü hakāyık1, İstanbul'daki rakipleri ne de On İkinci Şarl ve Kırım Hanı biliyorlardı. Bahusus ki bu Prut muzafferiyetinin neticeleri iyi oldu. Orada galebe elde etmeye alışmış orduları Şehit Ali Paşa birkaç sene sonra kolaylıkla Mora'ya sevk edebildi. Tekrar galebe yüzü görmüş ve düşmandan yılgınlığımızı gidermeye alışmıştık.

Bu mülâhazalarda bulunurken hatıra gelen diğer bir noktayı kaydetmeden kendimi alamadım. Bugün ben Baltacı Mehmed Paşa hakkında teessüs etmiş bir şâhideyi de tahrip etmeye çalışıyorum. Benden başkaları da tıpkı böyle milletin zihnine yerleşmiş diğer şâhideleri tahrip ettiler. Fakat...

\section{BİR TAHAYYÜL}

Madrid'de bu güzel Mart akşamı, kalbim milliyetimizin hüsranlarıyla bir daha dolu olarak tek başıma düşünürken bu hayale kapıldım: "Bundan yetmiş sene evvel, millet henüz sıhhat-gîn mehma-emken iyi yer, iyi giyinir ve iyi yaşarken, vatandaşlarımızın ruhları henüz bozulmamışken, hâsılı yeni bir heyecan aşısıyla dirilmek mümkünken, faraza, millet arasından büyük kafalı bir milliyetperverlik rehberi zuhur etseydi ve milliyetperverliğini sahih bir müddea hâlinde yoğursaydı acaba Şarkta ne kadar güzel bir hareket yaratırdı ve hatta Garbın gözlerini ne kadar hayranlıkla kamaştırırdı ve biz bugün ne hâlde bulunurduk!” dedim.

Bu hayali hakikatle mezcetmeye ve bir netice çıkarmaya koyuldum. Tahayyül ettiğim rehber olarak Namık Kemal'i aldım. Namık Kemal'in ruhunu aldım, hiç değiştirmedim lâkin Wagner' in ruhu derecesinde büyüttüm, kafasını aldım, hiç değiştirmedim lâkin Alman müverrihi Teramke'nin kafası kadar genişlettim ve Teramke Almanlığı ne mikyasta görüyor idiyse O’nu da milliyetimizi bütün vesikalarıyla ve bütün safhalarıyla geniş gören bir kâinat hâline soktum. Nesrimizdeki üslûbunu aldım. O’nun, nikbinâne, arslan kükreyişi gibi güzel, dalgalı ifadesini değiştirmedim lâkin Şark ağdasını ve süslerini bir tarafa attım, sadelikte fazla da ileri gitmeyerek mesela Michelet'nin üslûbu gibi halka kendini hikâye ederken halkın anlayışından ayrılmayan hisli bir akış hâline getirdim; nazmını Victor Hugo'nun millî kasidelerinde veyahut siyasî hicviyelerinde göründüğü gibi bol ve kolay akan bir nehir hâline ifrağ ettim. Bunları böyle tahayyül ettikten sonra Namık Kemal'i münhasıran bizi bize öğreten, ruhlarımızı sürükleyen, devlet, kanunlarımız, temeddün ve teceddüt usullerimizi sâlim bir mecraya sokan bir rehber olarak tasavvur ettim. Bu mucizenin tecellisinden sonra biz ne olurduk? Bugün ne hâlde bulunurduk? Bunu düşündüm. Kalbim fazla doldu, gözlerim hîrelendi. Ancak aklım bir noktaya saplandı, kaldı. Kendi kendime döndüm, dedim ki: "Ey bu neslin âciz ve cılız çocuğu; birçok nesildaşların gibi maziyi tashih etmeye çalışıyorsun. Lâkin hâl içinde tek bir yeni şey bulmaya ve söylemeye muktedir misin? Bundan da sarf-1 nazar acep bu daldığın tahayyülün hangi fikirlerle vücut bulacağını olsun, şimdi söyleyebilir misin?”

Evet, bu söylenişin en esaslı noktası budur. Bunu itiraf ederim. Bizim milliyetimiz salim ve sahih bir yolda nasıl inkişaf ederdi? Bunu tasarlamaya çalıştım. Yetmiş sene evvelki bu terkibi 
tasarlamaya başlarken, hayale dalıp da, vatanımızın hudut çerçevesini ve bu çerçeve içinde kaç cins insan cemaatinin yaşadığını unutmak ya tamamıyla mevhum bir müddeaya götürür yahut da Namık Kemal'in o zamanki "Mübhem Osmanlılık"ını bir daha canlandırır, hâsılı bizim milliyetperverliğimiz nasıl inkişaf edebildi?" gibi esaslı bir sualin sahih bir cevabını temin etmiş olmaz. Bunu unutmadım. Bunun için önce bu hakikî daireyi şerh etmek istiyorum.

Yetmiş sene evvel ortada bir millet, bir devlet, bir Hristiyan cemaatler kütlesi, bir de Namık Kemal vardı.

Yetmiş sene evvel millet, millete göre Türklerden, Araplardan, Kürtlerden, Arnavutlardan, Boşnaklardan, Çerkeslerden, Abazalardan, Lazlardan, Pomaklardan mürekkep bir Müslüman unsuruydu. Beliğ tabiriyle "Millet-i İslamiye" ve halk tabiriyle de "Muhammed Ümmeti”ydi. Bu saydığımız unsurlar vatan ${ }^{13}$

“Hürriyet” kelimesinin Arapça olmadığını, 1860’tan sonra İstanbul matbuatında zuhur ettiğini herkes bilir. Bu kelimenin ilk defa kimin tarafından ve hangi yazıda nasıl lisana geldiğine dair ciddî bir tetebbu da henüz çıkmadı. Fakat yanılmaksızın söylemek mümkündür ki Namık Kemal "hürriyet” fikrinin ve hissinin Türklük içinde yalnız en kuvvetli nâşiri değil, ilk nâşiridir de.

Namık Kemal'in "hürriyet" mefhumunu Fransız fikirlerinden telakki ettiği ise bu fikri teganni edişinin bâriz olan çeşnisinden her manzara tasvir(in)e kalkıştığı vakit, hemen daima 1789'dan sonra resim ve heykeltıraşî ile bütün dünyada taallüm etmiş olan ve New York Limanı önündeki heykelle adeta beşeriyetin kadın timsalini görmesi ile de lüzumundan fazla aşikârdır.

Namık Kemal'in Türklüğe nefh ettiği üç sihirli kelime "hürriyet, millet, vatan" kelimeleriydi. O yaşarken ve öldükten sonra, uzun müddet, bu üç kelime mânâca birbirinden ayrılmaz gibi telâkki olundular. Gerçi 1789'dan sonra diğer Avrupa milletlerinde de aynı tecelli vâkî olmuştu. Bu telâkki o zamana göre gayet tabiîiydi de. Milletler, "milliyet" kelimesiyle, "hürriyet" kelimesini birbirinden ayırmıyorlardı. Çünkü birçoğu milliyet fevkinde bulunan sınıflardan ve hükümdar hukuklarından kurtulmak kaygısında idiler. Münhasıran kendi kanlarından olan vatandaşlarla meskûn topraklarda yani "vatan" toprağında oturan milletlerin bu telâkkisi tabiî idi. Kendi vatanları başka bir milletin istilâsı altında bulunan milletlere göre bu telâkki daha çok tabiî olduğu âşikârdı. Binaenaleyh kendi vatanları haricinde fethedilmiş araziye ve teb'aya mâlik olan milletlere göre ise doğru değildi, gibi görünebilir. Mamafih on dokuzuncu asrı hürriyet tegannisiyle dolduran Victor Hugo, Cezayir' in fethine itiraz etmemiş, o zamanın en hararetli hürriyetperverlerinden olan İspanyol ahrârı da gerek Amerika' da ve gerek Afrika'da olan mevrûs topraklarından bir an vazgeçmemişlerdi. Bu hürriyetperverlere böyle düşünüşlerinin sebebi sorulsa gayet mutekidâne bir cevap vererek derlerdi ki: “Cezayir'de hürriyet yoktur, biz temin ediyoruz, Amerika'da ise kendi lisanımızda olan millettaşlarımızla ayrı-gayrımız yoktur, hepimiz beraber hür olacă̆ı!!" Gerçi Victor Hugo, Cezayir'in Fransa sayesinde olacağı yerde, İngiltere sayesinde hür olmasını, İspanyol hürriyetperverleri de

13 Bu kelimeden sonra bir sayfa eksik olduğu hissi uyanmaktadır. 
cenûbî Amerika'daki lisandaşlarının İspanya'dan ayrılarak bir arada yahut da ayrı ayrı hür olmalarını hoş görmezlerdi. Çünkü bu şekil fazla mütehassis oldukları "milliyet" hislerini rencide ederdi. Böyle olmakla beraber şüphesiz hürriyetperverdiler. Bu misalleri zikretmekten maksadım Namık Kemal'e vâkî olacak mefruz bir itirazı baştan reddetmektir. Namık Kemal, bütün "memalik-i şâhâne”yi “vatan” çerçevesinde görmekle kendi kendine karşı mantıkî idi. Zira O’nun milliyetperverliğinin esası İslâmiyet'ti. O’nun vaktinde ise “memalik-i şâhâne”nin bütün büyük kıtalarında Müslüman ekseriyeti vardı. Vatanı, en hazin bir ânında "bir kolunu Ravza-yı Nebî'ye, bir kolunu da Kerbelâ' da Meşhed'e atmış ve siyaha bürünmüş” bir şekilde gösteren Osmanlı şairinin vatana yalnız çizdiği $\ldots{ }^{14}$ değil, verdiği Müslümanca mânâ da sarîhtir. Namık Kemal'in maruf makalesiyle Beyoğlu'nda vatanperverane şarkılar söyleyen Rumlara hücumu, Karadağlılardan, Araplardan, Bulgarlardan, zaman zaman şiddetle bahsedişi de hürriyetperver olmadığına delâlet edemez, çünkü bu unsur(lar) o vakit "memalik-i şâhâne" dâhilindeki kıtaların hiçbirinde ekseriyet hâlinde değillerdi. Mamafih Namık Kemal'in "vatan" ve "ümmet" telâkkileri ayrıca tenkit edileceğinden münhasıran "hürriyet" telâkkisi bahsine geçiyorum.

Namık Kemal'in "hürriyet" telâkkisi en ziyade, Rüya'sında ve "Görüp ahkâm-ı asrı...." manzumesinde, Tasvir-i Efkâr'a yazdığı bazı makalelerinde görülüyor. Hayatında "hürriyet” için olan... ise yazılarından daha fazla mahsustur demek doğrudur. Rüya'sı en kuvvetli eserlerinden biri değildir, müfrit bir derecede beligâneydi. Hemen "fikir"den (ziyade), hayalin ve hissin cûşân olduğu bir eserdi. Rüya'da hürriyete dair bir düşünüş tarzını zapt u tespit etmek çok ruhiyât mütehassısı bir münekkidin bile kârı değildir.

“Görüp ahkâm-ı asrı...” manzumesine gelince, hürriyeti sevmek zevkini bu milletin ruhuna çok şümullü derecede zerk etmiş olan birkaç mısraıyla mütalaa etmek zarureti vardır. Bu mısralar, altmış seneden beri ihtiyar, genç, zâbit ve sivil çok büyük kütle üzerinde hudutsuz bir tesir icra edebilirler. Samimî bir insanın kalbinden vehleten feverân etmiş lâv parçaları olduklarından her düştükleri kalpte aynı samimiyeti uyandırdılar. Bu mısraları kuvvetli şairlerimiz, lisanca hâbîde ve gayr-i saf ve "berceste" nâmını alan yekpâre mısralar gibi yüksek bir sanat nev'inden uzak telâkki edebildiler. Aynı zamanda halk taraftarları halka hitap eden bu mısraların, Türk halkının lisanından olmadığını söyleyebilirler. Fakat hakikat budur ki o zamandan beri söylenen çok "berceste" mısralarımızın hiçbiri bunlar gibi hem şiddetli, hem medit, hem de engin bir tesir icra etmediler. Halk lisanıyla inşat olunmuş diğer vatanperâne şiirleri de bu mazhariyete ermediler.

İspanya'da ve Lehistan'da edebiyatın üçüncü plâna düşüşü.

Namık Kemal'in tercüme-i hâli münasebetiyle, gençlerin bir zaman itibarı. Bunu yapan üdebadır.

Novel: Tramvay Biletçisi: Eski .....in hikâyesi ${ }^{15}$

14 Sayfanın burası yırtıktır.

15 Bu ifadeler, bir başlık şeklinde daha küçük harflerle sayfanın en üst kısmına yazılmışlardır. 
Namık Kemal'in yıldızı nasılsa bir daha parlıyordu; artık vasiyeti mucibince mezar taşına "vatan mahzun ben mahzun" cümlesini yazamayız. Çünkü namını tes’id etmek için yazılan makalelerde, söylenen nutuklarda, çıkan kitaplarda, bugünkü feyzimize evvelâ O’nun sebep olduğunu söyleyenler oldu.

Bu büyük adamın tes'id edilmesi vesilesiyle hatırımdan bir şey geçti. Tercüme-i hâli, bu defa hayli iyi yazıldı. Hangi sene, nerede doğduğu, nasıl yetiştiği, nasıl yaşadığı, nasıl öldüğü anlaşıldı. Kırk sekiz yaşını doldurmadan öldüğünü de öğrendik. Allah Allah! Demek ki, resimlerinde o gür saçlı, o mehîb yüzlü gördüğümüz adam kırk sekizini bile doldurmamış. Hâlbuki biz neslimizde kırk sekizini aşmış nice siyasîlere, ediplere, âlimlere henüz adam olmuş nazarıyla bakmıyoruz. Zaten siyasî hayatta, edebiyatta, ilimde icraatta bulunanlar, birbirlerine asla adam nazarıyla bakmıyorlar. Bereket versin, onlara yine, onların âlemi haricinden olan vatandaşlar bir kıymet veriyorlar. Meselâ tam mânâsıyla yetişmiş bir edibimize, kendini vatan uğrunda belâlara uğratmış bir siyasîmize, ilimde Namık Kemal neslinin varamadığı bir dereceye varmış bir âlimimize, eğer isimleri işitilmemiş kenar insanları bir kıymet vermeseler, zamanımızda kıymet denilen şeyi asla idrak edemeyeceğiz.

Mevzumuzdan ayrılmamalıyım ve misal olarak Namık Kemal'i alalım. Namık Kemal 1840'ta doğacağına 1880'de doğsaydı ve 1908 inkılâbında 28 yaşında bulunsaydı şimdi de altmış yaşına girseydi şu tahayyül ve tes'id ettiğimiz gür saçlı, mehîb yüzlü, adam mı olurdu? Misalimizin siyasî cihetten mukayesesini bırakalım. Çünkü bu cihet çok dikenlidir, yalnız edebî cihetten mukayesesine girişelim: Evvelâ 1880'de doğmuş olacak bu Namık Kemal, kaçıncı defa yıpratılır, kaçıncı defa eskitilir, kaçıncı defa "battal” damgasını yerdi ve bu felakete münhasıran her yaşta olan ediplerimiz tarafından uğrardı. Hülâsa O 1840’ta doğmuş ve hayırlısıyla 1888'de ölmüş, ortadan silinmiş olan öteki Namık Kemal asla olamazdı. Evet, aynı değerleri hâiz olmak şartıyla olamazdı.

Namık Kemal'i bildiğimiz şahsiyet eden münhasıran kendi hilkati değildi, mühim bir mikyasta içinde yaşadığı cemiyetti. Yani bizim büyükbabalarımızın nesli, o nesildi. Onlar bizden saftılar, "kıymetler" karşısında bizden ziyade saygı hissine sahiptiler, bir adama adam sıfatıyla bakmasını bilirlerdi. Bunun için de Namık daha yirmi beş yaşında iken birdenbire çok parlak bir şahsiyet oluvermişti. Biz gafiller, O’nun bazı mısralarını okurken o mısraları beğenmiyoruz veyahut otuz yaşında bir gencin söylediğini fark etmiyoruz! Onları söyleyen insan bize başka başka, çok farklı, çok farklı bir şahsiyet görünüyor. Acaba o şahsiyet bizim neslimizden olsaydı öyle mi görünürdü?

Bu bahsin künhüne kadar bir tahlil tecrübesine girelim: İçinden çıkan şahsiyetleri ölçüsüz bir coşkunlukla büyüten cemiyet, iptidaî bir cemiyettir. Bazen de çok müterakkî bir cemiyet, kaderinin sevkiyle, birdenbire hârikulâde vakalar içine coşkunlukla karışır ve bir destan rüyası yaşar; meselâ Fransızların Napolyon devri gibi. O mahdut devrede başta bulunan serdar yahut hükümdar etrafındakilere birer ilah gibi mehîb görünürler. Muhayyile o zaman her şahsı ve her vak'ayı büyütür. Bu da safvet yani iptidailik hâlidir. 
Ahlâkın inkıraz ve inhilâl devirlerinde de bilâkis cemiyet, en değerli şahsiyetlerini yıpratır, küçültür, kirletir, düşürür. Cemiyetin sıhhatli zamanında ise şahsiyetlerin değerleri meydana çıkar, çehreleri fertlerin muhayyilesine nakş olunur, sözleri dillerde gezer ve zihinlerde yer tutar, hatta kimse farkında olmadan devlete istikamet verir.

Biz şimdi bu üç safhanın hangisinde bulunuyoruz? Hiç iptidaî olmadığımız muhakkaktır. Tam bir ahlâk inkırazı içinde mi pûyânız? Asla. Çünkü halkın ahlâkı Namık Kemal devrinde olduğu kadar saftır. Bu bahiste söze başlarken söylemiştim: Bereket versin, değerlere, isimleri işitilmemiş kenar adamları eskisi gibi kıymet veriyorlar, onlar haset nedir biliyorlar, rekabet garazlarından uzaktırlar, beğendiklerini beğeniyorlar, fikirlerini şu ve bu sâikle kolay kolay değiştirmiyorlar, aynı zamanda çirkinliklere, âdîliklere, seciyesizliklere de balmumu yapıştırıyorlar, bu bahiste de hükümlerinden vazgeçmiyorlar. Evet, meslekleri haricinde bî-taraf bir müşâhit sınıfı, bir hakem heyeti var. Bugün Türk ilinde sanat da, ahlâk da, edebiyat da onun sayesinde durabiliyor.

\section{ABDÜLAZİ'İN HAL'İ}

Abdülaziz'in hal'i, birbiri arkasından, kaza ve kaderin akışına benzeyen bir sürü hadiselere sebep olduğundan, o zamandan beri siyasî tarihimize meraklı olanları düşündürüp duruyor.

Bu bahis üzerinde dururken, Abdülaziz'in hal'inin asıl sebebi nedir? Bu sebebi uzun seneler araştırıp durdum. Nihayet bir neticeye vardım. Bu sebebi keşfettim sanıyorum.

“Abdülaziz'in hal'inin asıl sebebi nedir?” denilince hatıra neler gelir, biliriz. Milliyet ve inkılâp fikirleri tarafindan olanlar derhal 1876'ya doğru devletin maliyesinin bir çıkmaza girdiğini, idaresinin bozulduğunu, üstelik Rusya'nın İslâv Birliği dâhiyesiyle ortalığı karıştırdığını ve Padişahın bütün felâketler karşısında kayıtsızlığını, hülâsa hal'in ve meşrutî bir idarenin kurulması zaruretini öne sürerler. Muhafazakâr ve saltanatçı olanlar ise 1876 'da vükelânın nefsaniyetlerine kapılarak Padişahı hal ettiklerini ve başımıza o zaman ve o zamandan beri umulmaz işler açtıklarını söylerler.

Bu iddiaları şimdiye kadar kaç kerre dinledik ve okuduk.

Gelen iki tarafin iddiası da ikinci safta olan sebeplerle doludur. Bu sebeplerin hepsi ve her biri mevcut olurdu da Sultan Abdülaziz yine tahtında oturabilirdi. Aynı sebeplerin ziyadesiyle mevcut olduğu devirler biliriz ki işi başında olan padişah yahut müstakil sadrazam yani devrin diktatörü yerinden kımıldamamış ve kımıldatılamamıştır. Abdülaziz için de aynı mülahaza vârid olurdu.

Öyle ise bu padişah niçin hal edildi? İktidar mevkii her zaman ve her yerde kendini isteyen adamı ister ve bulur. Eğer o adam padişahsa ona râm olur, o değilse, onu dizgini altında tutar bir adam arar. Bunun içindir ki bizim tarihimizde padişahlık etmiş padişahlar olduğu gibi padişahları da emir kulu gibi idare isteyen birçok vezirler, harem ağaları, silahtarlar, nedimler ve hatta saray haricinden Hâlet Efendiler zuhur etmiştir. 
Abdülaziz kendi devrinde iktidarı benimsememişti. Mührünü birinden alıp birine verebildiğini gördükçe Padişah, iktidarına sahip olduğuna inanıyordu. 1871-1876 seneleri ise iktidar mevkiinin en ziyade boş kaldığı bir devre idi. Âli Paşa'nın 1871 Teşrinisâni'sinde ölmesiyle beraber o yer boş kalmış, bir türlü doldurulamamıştı. Abdülaziz bu devrede dokuz defa sadrazam değiştirdi ve Mahmud Nedim, Midhat, Mehmed Rüştü, Esat, Şirvânîzâde Rüştü ve Hüseyin Avni Paşalara mührünü verdi. Bu sadrazamlar, birer birer meyus ve Abdülaziz'e karşı emniyetleri kırılmış olarak çekildiler. Hatta hal'den evvel Esad ve Şirvânîzâde Rüştü Paşalar başlarından oldular. Diğerleri, dediğimiz gibi Abdülaziz'den ümitsizdiler. Hatta en ziyade Saray taraftarı ve Pertevniyal Valide'nin adamı tanılan Mahmud Nedim Paşa bile halin olduğunu işittiği zaman bundan başka çare kalmadığını itiraf etmişti.

\section{RÂGIB EFENDİ}

1900’a doğru Üsküp'te bir Râgıb Efendi vardı. Gilanlı bir gençti. O da bizim gibi Leskofça muhacirlerindendi. Hicretten sonra ailesi Gilan'a hicret ettiği için orada doğmuş ve büyümüştü. Kosova vilâyeti polisinin idare ve kitabet işlerinde istihdam ediliyordu. Rütbece polis neferi ise de kâtip olduğu için memur sayılıyordu.

Bu Râgıb Efendi uslu, edip, okumaya ve öğrenmeye meraklı bir insandı. Vazî’ bir hayat içinde yaşadığı için mütevazı ve derviş-meşrep görünmekle beraber gurur-1 nefs sahibiydi. Etrafına kafalı bir adam olduğunu teslim ettirmişti. Herhangi muhitte bulunursa bulunsun, etrafını tahakküm altında bulunduran bir şahsiyeti vardı. Muhacir Mahallesi'nde otururdu; zannedersem bir validesinden başka kimsesi yoktu. Sabah erken, Polis Dairesi'nde işi başına gelir, akşam dervişâne yürüyüşle evine dönerdi. Kahvede, eğlence yerlerinde, rakı sofralarında asla görülmezdi; temiz ve ahlâkı su götürmez birisiydi.

1901'de Râgıb Efendi’yi tanıdım. Bu adamın kafam üzerinde büyük bir tesiri oldu. O’nun Polis’teki küçük kalem odasına devam etmeye başladım. Bu oda, Tanzimat'tan evvelki eski Hükümet Konağı'nın altında, Polis'e tahsis olunmuş dairede, küçücük bir oda idi. Kosova Polisi'nin bütün işleri bu odada, Râgıb Efendi'nin elinden çıkardı; çünkü Râgıb Efendi, bilâhare Rus Konsoloshanesi'nde mühtedi bir polis neferi tarafından katedilen ve Makedonya komiteciliğine karşı yüksek bir zekâ ve celâdetle karşı koyan maruf polis müdürü Derviş Efendi'nin en emîn memuru olduğu gibi yakın dostu idi de. Râgıb Efendi'nin edebiyata meylini, intişar etmiş kitaplara âşinalığını anladıktan sonra ziyarete başlamıştım. Ülfetim arttıkça O’nda daha esrarengiz vukuflar olduğunu sezdim. Râgıb Efendi, Namık Kemal'in şeyda bir hayranıydı; Yeni Osmanlılığın ve Genç Türklügün bütün şahsiyetlerini, bütün eserlerini bildiği gibi, o sıralarda kaynaşan bütün siyasî fikirleri, Makedonyacılığı, Arnavut milliyetçiliğini, Rumeli'nde dönen Avrupa entrikalarını iyi biliyordu. Padişahın, sarayın, hükümetin aleyhindeydi. "Evrâk-1 muzırra" denilen siyasî neşriyatın tadını almış bir mütefekkirdi. Bana karşı emniyeti arttıkça Namık Kemal'in Rüya'sını, Şefik namında bir Jön Türk'ün Hareket isimli şedit bir risalesini, Zafername Şerhi'ni ve bunlara mümasil, o zaman şiddetle memnu birçok tehlikeli yazıları gösteriyordu. Râgıb Efendi’nin tıpkı kendi (gibi), Polis’te kâtip bir arkadaşı vardı. Adı 
Halim Efendi idi. O da tıpkı O’nun gibi halûk, temiz, aile çocuğu kâtip bir insandı. Hükümet kapandığı zaman Halim Efendi gelir, Râgıb Efendi'nin odası, en tehlikeli bahisler üzerinde telezzüzle konuşulan bir mahfil olurdu. Bu ülfetle vatanın mukadderâtı hakkında ilk defa bir müşahede sahibi olmuştum.

Râgıb Efendi Gilan'da, Arnavut muhitinde doğduğu hâlde hakikatte Arnavut değildi; Türktü. Lâkin Arnavut fikirlerine mütemayildi. Halim Efendi ise irken Arnavuttu. Meşrutiyet'ten sonra bu iki insan önce İttihat ve Terakki'nin hararetli birer taraftarı olmuşlar sonra muhalefete başlamışlar, kendilerini Arnavutluk cereyanına kaptırmışlar, Balkan Harbi’ni müteakip Üsküp, Gilan, bütün o taraflar harp boyunduruğunun altına düşünce perişan olmuşlar; o zamandan beri haberlerini alamadım. Bu zavallı Leskofçalı genç, vazi’ bir aileden doğarak oralarda metruk kalmasaydı muntazam bir tahsil görseydi şaşırıp milliyetimizden ayrılmasaydı bu devrin başlıca şahsiyetlerinden biri olabilirdi. Çünkü fikirde ve ahlâkta tam mânâsıyla idealistti ve dediğim gibi, Leskofçalı bir Türktü de.

\section{DİBACE KILIKLI}

Nice tavırları, nice edaları, nice cümleleri, nice meselleri, zarafeti bir kelebek gibi uçuran Fransızcada "Bakınız: Tarih nasıl yazılıyor!" diye bir söz vardır. Bu sözün yine müstehziyane bir hakikat olduğunu ömrümde kaç ve kaç defa gördüm. Yaşadığım şu otuz sene içinde yakından tanımış olduğum insanların ve gözlerimin önünden geçmiş vak'aların daha şimdiden ne kadar zıt mahiyette tarihe mâl olduklarını seyrettikçe gayr-i ihtiyarî gülümsedim ve kendi kendime "Bakınız! tarih nasıl yazılıyor!" dedim.

Bu tecrübemin sevkiyle birkaç defa şu mülâhazaya daldım: Jön Türklüğün son beş senesi zarfında, Paris'te onlarla düştüm, kalktım. Sonra İstanbul'a döndüm; Halaskâr Vak'ası'ndan başlayarak sıra ile Balkan hezimetimizin içyüzünü ve dış manzarasını, daha sonra Babıâli Vak'ası'nı, daha sonra Cihan Harbi'ne girişimizi ve harpte çalkandığımız o dört seneyi, daha sonra dört senelik Mütareke'nin renk renk safhalarını, daha sonra Lozan Musalahası'nı, daha sonra Cumhuriyet'in ilânını ve inkılâbın en mühim merhalelerini gözlerimle gördüm. Bu yirmi sekiz seneyi, şimdiye kadar belki hiçbir müverrihin tecrübe etmediği bir usulde yazsam yani bu devir içinde şahidi olduğum vak'aların ve tanıdığım aktörlerin "görünüş" cihetini münasip bir tarafa bıraksam ve bu devrin yalnız ve yalnız şimdi unutulmuş ve hatıralardan silinmiş ruhiyetlerini? tespit etsem, samimî bir eser vücuda getirmiş olmaz mıyım?” dedim.

Şimdi Madrid'de boş zamanlarım var. Bu düşünceme vücut vermeyi tasarladım. Yalnız eserime başlamadan önce ne yapmak istediğimi iyi izah edeyim ki karilerime baştan bir kolaylık olsun.

Ben dikkat ettim, milletlerden yetişen çok kudretli insanlar, yalnız vak'aları yoktan var etmekle kalmıyorlar fakat kendileri gibi kuvvetli olmayan ve sürüklenen insanları kendi sun'î eserlerine inandırıyorlar da. Yani maruf bir tabire yeni bir şekil vererek "Tarihi hem yapıyorlar hem de yazıyorlar!” Artık tarihe dair değil fakat ekseriya onların telkin ettikleri gibi kalıyor. 
Şüphesiz ki bu hâl, şuurlu ilerlemiş, hür içtihatları olan, gören ve göstermekten korkmayan milletlerle şuura uyuşuk, geri, esir yaratılmış, görmediği gibi, göstermek meziyetinden (mahrum) milletler arasında hayli farklı olarak tecelli ediyor. Maatteessüf biz Türkler bu ikinci nev milletlerden değilsek bile bunlara yakınız. En bariz ve kaba-saba misaller hatırımdan geçiyor. Meselâ: Bütün varlığımızın tarihinde en müthiş bir felâketin başlangıcı olan 1915 harbimizin başlangıcını bir Harbiye Nazırı koca Türk efkâr-1 umumiyesine istediği şekilde hazmettirdi ve Alman amiralinin emr alarak Karadeniz'de Rus filosuna tecavüz ederek harbi açtığını, harp bittikten ve diller çözüldükten sonra çok azim bir ekseriyeti hâlâ 1914'te efkâr-1 umumiyeye yutturulduğu şekilde terennüm ediyordu. Diğer bir kısım da bu felâket başlangıcına hiçbir ehemmiyetli hadise gibi bakmiyordu. Diğer bir kaba misal: Bunu Balkan Harbi'nin ortasında hayretle temaşa etmiştim: Bâbıali Vak'ası olduğu vakit, hükümet, Midye - İnoz ${ }^{16}$ hattından bîçare bir hududa razı olmuştu, yani Edirne'yi düşmana bırakmıştı. İttihat ve Terakki, "Edirne" feryadıyla Bâbıali'yi bastı ve muvaffak oldu, hükümeti eline aldı. Felaket ortasında hakikaten vatanperverane son bir cidale atılarak Rumeli'den hiç olmazsa Edirne şehrini kurtarmaya çalıştı. Fakat bir daha mağlup olduk. Nihayet "Edirne"yi almak ahdiyle hükümeti ele alan bu kuvvet Edirne'yi verdikten başka daha kötüce bir hudut hattına da razı oldu ve bu rızasını devletlere beyan etti. Londra'da Balkan Sulhnamesi'nin metni bile basıldı. İttihat ve Terakki hükümeti "Edirne" bahsini sihirbazlığa benzeyen bir el çabukluğuyla efkâr-1 umumiyenin karşısından kaybediverdi. Fakat Balkan müttefiklerinin ekseriyeti birdenbire Bulgaristan üzerine atıldılar, Sofya'ya doğru yürüdüler, İttihat ve Terakki hükümeti yine samimî bir vatanperverlikle bir daha silaha sarıldı. Ve gerek talih, gerek de kendi gayreti semeresi olarak Edirne'yi az bir kan pahasına geriye alıverdi ve alınca da efkâr-1 umumiye karşısında Bâbıali’yi bastığı günkü Edirne nakaratını bir daha tutturdu. Herkese gayet ciddî olarak: "Size ne demiştik? Edirne'yi almadan sulh etmeyeceğiz" demiştik değil mi? İşte biz erkek insanlarız, sözümüzü yerine getirdik, görüyor musunuz? Edirne'yi ve Kırkkilise'yi aldık!” dedi ve Türk efkâr-1 umumiyesi bu sihirbazlığı hararetle hazmetti. $\mathrm{O}$ vakit işittim ki ne kadar görüştüklerim ve tanıdıklarım, Balkanlılar, Bulgaristan üzerine yüklenmeden önce İttihat ve Terakki hükümetinin Midyeİnoz hattından daha kötü bir hattı, hudut olarak resmen tanımış olduğunu bilmiyorlardı bile. Edirne'yi geriye aldığından, hiç sevmediğim Enver'e ve İttihat ve Terakki'ye karşı çok derin bir muhabbet duymuştum. Bir Rumeli Türk'ü olmam bu muhabbeti artırıyordu. Ancak "Edirne" münasebetiyle gözüm önünden geçmiş olan bu komiteci sihirbazlığa bakarak: "Yalnız işin bu safhası bu millet için berbat bir alâmettir çünkü vatanın en aziz bir kısmına ait bir arazi terkini gözüyle görmeyen bir milletin bir gün birkaç vilayeti çalınsa ve bu facia iyi gizlenebilse bir mesele bile çıkmaz!" diyordum. Nitekim bu meş’um tahminim hem de üç sene sonra tahakkuk da etmedi değil. Zira 1915'te Enver, yalnız birkaç kişi ile görüşerek ve matbuata bir tek satır aksettirmeyerek, mahza Bulgaristan'1 memnun edip harbe iştirak ettirmek için Dimetoka'yı peşkeş çekti. Bu tedbir doğru muydu, yanlış mıydı? Bulgaristan Dimetoka’yı almaksızın da Cihan Harbi'ne iştirak etmez miydi? Bunu kimse kāle almadı. Nitekim Bulgaristan'ın harbe girmesinin esbabına dair intişar eden vesikalar ahîren gösterdi ki Enver’in Boğazları ve İstanbul'u bir an evvel kurtarmak ve Almanya ile iltisak peyda etmek için gösterdiği istical ve

16 Enez 
Dimetoka'yı vermesi azîm bir toylukmuş ve bir komiteci Tofkiciyev? kendisini iyiden iyiye aldatmış Kral Ferdinand, mahza Makedonya komitesine isnat edip Bulgaristan'da payidar olmak için Almanya cihetinden harbe girmeye katiyen karar vermiş, zaten istese bile aksini yapamazdı. Bu kaba misalleri zikretmekle yalnız müddeamı biraz takviye etmek istedim yani bizim tarih, gözümüz önünden geçerken bile onu nasıl gördüğümüzü anlatmaya çalıştım. Fakat benim bu eseri yazışımdan maksadım birkaç adım ileri bir sahadadır.

Maksadım siyasî, askerî, adlî vesikalar göstererek tarihi talim etmek değildir. Zaten böyle vesikaları ne aradım ne de aramaya lüzum görüyorum. Hülâsa edeyim:

Benim maksadım, şahidi olduğum bu devrede Türkiye'de kimsesi, müdâfii, yâr-1 vefâkârı olmayan hakikati ben safha safha nasıl gördüm, bunu yazmaktır. "Ben nasıl gördüm?" kaydını bir daha tekrar edeyim ki iddiâkâr olduğum anlaşılmasın.

\section{ABDÜLHAMID İDARESİ - PARIS'TE ve AVRUPA'DA JÖN TÜRKLÜK}

Yirmi seneden beri bizden ve ecnebilerden her düşünen dedi ki: “Abdülhamid, bu milletin eski usulde son padişahıydı. “O’nun sukutuyla eski Osmanlı saltanatı kapandı.” Bunu böyle göstermeye yardım eden şekillerin hem çok ve hem de çok aldatıcı olduklarını itiraf ederim. Abdülhamid birçok itibarlarla eski bir Osmanlı padişahını andırıyordu; kendisi Avrupa irfanı ve terbiyesi gayet zayıf olan bir adamdı; son üç asır zarfında gelmiş ve geçmiş birçok sultanlar gibi sarayına kapanmış, yaşıyordu. Bilhassa Şarklı ve Müslümandı. Hilafeti padişahlıktan üstün tutan bir hâlet-i ruhiyesi vardı. Çok bariz olarak, Avrupa tesirlerine karşı memleketi kapıyordu ve eski Türkiye'yi muhafaza etmeye çalışıyordu. Kendi oğulları ve kızları Frenkleşmekle beraber, kendi, memleket hesabına anane-perestti. Herhâlde aykırı alafrangayı bazı safhalarda serbest bıraksa bile kendi, yaşamıyordu. Meselâ "Edebiyat-ı Cedide"nin intişarına müsaade ediyor fakat kendisinin sarayı ona bigâne kalıyordu. Abdülhamid erkânının daha ziyade alaturkaya yakın bir "baloz" alafrangasına temessül kabiliyeti vardı, denilebilir. Hâsılı Abdülhamid'in kendi ve devri, "millı̂” bir çeşni sahibi idi.

Mamafih iyi, derin ve sağlam bir görüşle Abdülhamid ve millet arasında o zaman elle tutulur kadar bariz bir bîgânelik mevcuttu. "Bu padişah, tâ cülûsundan beri bu milletin kalbinde müspet bir mevki tutmad»" demek doğrudur. Millet, en büyük bir mikyasta, Midhat Paşa ile Namık Kemal'in ve sonraları Jön Türklüğün tesirlerinden tamamıyla uzaktı. Fakat Abdülhamid'e de bîgâne idi. O otuz üç sene zarfında Abdülhamid'i candan seven bir Osmanlı'nın, doğrudan doğruya Yıldız Sarayı'na mensup bir fert olduğu âdeta bir fârika gibi göze çarpardı. Hâlbuki seleflerine nispetle hâl böyle değildi. Kardeşi Sultan Murad'ı hakikaten sevmiş ve O'nu iyi bir padişah olarak temsil etmiş, saraya ve hükümete asla mensubiyeti olmayan yüzbinlerce insan görülmüştür. Abdülaziz'i ise avam tabakanın bilhassa sevdiği mütearife hükmündedir. Abdülmecid'i gerek havas ve gerek avam hürmetle ve muhabbetle benimsemişlerdi; Sultan Mahmud'un, müteaddit tedhişleriyle ilka ettiği korkuya rağmen milletin kalbinde büyük bir yeri olduğu muhakkaktı. Abdülhamid'e gelince, vaziyet bambaşka idi. 
Bir defa bu padişah, bir millete muhabbet ve hatta hürmet telkih eder bir yaratılışta değildi. Hatta zannederim ki kendini, sun'î çarelerle sevdirmek ihtiyacını bir dakika hatırına getirmemişti; şahsına hürmet tevcih etmek için gazetelerde, resmî kâğıtlarda istimal ettirdiği basmakalıp tabirlerde nice kurnaz hükümdarın ihtiyacını hissettiği ve para vererek vücuda getirdiği neşriyatı Abdülhamid arzu bile etmemişti. Meselâ ne kadar gariptir ki cülûsunu müteakip Ahmed Midhat Efendi'ye mahsus sarayda yazdırılmış olan ve hakikaten gerek 1876'daki inkılâp vak'asını, gerek de Rusya harbini tamamıyla Abdülhamid'in lehinde ve düşmanlarının aleyhinde gösteren Üss-i Ínkılâp ve İhkak-ı Hak gibi iki kitabı bu padişah, devrinin bir kısmından sonra ortadan yok edivermişti. Görülüyor ki şu neşriyat denilen gürültünün lehte olanından da, aleyhte olanından da mütevahhişti.

Abdülhamid'in gerek Avrupa' da ecnebi lisanlarıyla, gerek de o zamanki Türkiye'de Türkçe ve Arapça ile kendi propagandasına ciddî bir ehemmiyet atfettiği anlaşılır.

Bir kelimede hülâsa etmek lâzım gelirse: Abdülhamid, "menfi” bir usulde saltanat sürdü. Devrinin bu farikası cülûsundan sonuna kadar aşikârdır. Gayr-ı muntazar bir hadise ile tahta çıkmıştı. İlk sevk-i tabiîsi, tahtı ve hayatını korumak olmuştu. Artık bu histen öteye gidememişti. $\mathrm{Bu}$ hissi, milletle kendi arasında bir soğukluk değilse bile bir durgunluk vücuda getirmişti. Bir hükümdar veyahut bir hükümet kendi lehinde velev aldatıcı mahiyette olsun "müspet” tahayyüller icat etmezse "menfi" cereyanın kendinden derhal başlaması tabiîdir. 10 Temmuz' da bütün bir milletin birdenbire Abdülhamid' in aleyhine dönmüş olmasını birçok şahitler, o devrin artık çok sürdüğünü ve herkesin artık "illallah” demiş olduğunu zannederek tefsir ediyorlar. Hâlbuki bu müşahede çok yanlıştır. Abdülhamid Rusya Harbi’nin sersemliği geçtikten biraz sonra devrinin herhangi bir merhalesinde sukut etseydi aynı hâl vâki olurdu; Abdülhamid yine 10 Temmuz'da olduğu gibi, etrafında anca saray erkânından birkaç taraftar bulabilirdi. Abdülhamid meselâ en büyük muvaffakiyeti olan Teselya Harbi'nde sukut etseydi bütün millet ve bütün ordu aleyhine bir anda dönebilirdi. Bu menfi mahlûk, ordularımız Dömeke'ye yürürken bile bir an müspet bir tahayyül vücuda getirmeyi düşünmemişti; belki o harpte kafasını yegâne işgal eden nokta, bu seferberliğin, bu gürültünün birdenbire aleyhine dönecek bir hadise çıkarması olmuştu.

İkinci bir müşahede: Millet o devirde Abdülhamid hükümetini tabiî bir şey telakki etmiyordu. Vâkıa eski Osmanlı saltanatının tabiî bir devamı değildi de.

Eski Osmanlı usulü, yani millete tabiî görünen usul "Vak’a-yı Hayriye” ile kapanmıştı. İlk Tanzimat'la beraber şöyle-böyle yeni bir usul başlamıştı. Reşid, bu usule "Bâbıâli" diye bir şekil vermişti. Artık herkes anlamıştı ki "devletin kanunları vardır, bu kanunları Bâbıâli çıkarır ve icra ettirir, Padişahtan başka "devlet” diye bir şey vardır, "devlet”" merkezdir; Bâbıali taşradır. Hükümet konakları, birçok paşalar, önü ilikli İstanbulinli kâtipler ve . ... ${ }^{17}$ onun zaptiyeleridir; Sadrazam bu milletin bir nevi vasîsidir. Padişah, O’nsuz bir adım atamaz. Bu Sadrazam denilen "zât" ise saçını- sakalını kalem odalarında ağartmış efendilerden yetişir, etrafındaki vezirler de o nev'idendirler. Evet, Vak’a-yı Hayriye'den tâ Midhat Paşa'ya kadar bu iş ve bu anlayış

17 Aslî metnin burasında bir eksiklik söz konusudur. 
kafalara yerleşmişti. "Bâbıâli’nin “saltanat hukukunu” böyle benimsemiş olması Padişahın ve Osmanlı hanedanının vâsi mikyasta işine yaramıştı. Çünkü Padişahı ve hanedanı halkın ta’n ve düşnamından müberra kılmıştı. Abdülmecid'in ve Abdülaziz'in halk tarafından sevilmiş olmalarında bu sırra ehemmiyet vermek lâzımdır. Eğer Abdülmecid devrinde "Bâbıali"nin vücudu olmasaydı ve bütün işler Dolmabahçe Sarayı'nda görülseydi Abdülmecid'in kendisinin ve çok açık-saçık olan aile hayatının efsaneleri, Sultan İbrahim devri gibi halkın lisanına düşerdi. İkinci misal daha barizdir: Abdülaziz bilhassa kendi şahsî isrâfâtıyla mâlî iflâsımıza sebep olduğu hâlde hal olunduğu vakit millet tarafından itham edilmemiş, bilâkis acınmıştı. İflasın yegâne müsebbibi olarak "Mahmud Nedim Paşa" görülmüştü. "Bâbıâli"nin şekli, Padişahı ve hanedanı bu derece lekeden masun tutuyordu.

Abdülhamid'in cülûsundan bir müddet sonra şekil de iş de değişti. Yıldız Sarayı bütün işlerin, emirlerin, tesirlerin merkezi olmaya başladı. Bu usul-i idare, Türkiye'ye göre yepyeni idi. Zaten Yıldız gibi yeni bir tepe, mevki idi. Vak'a-yı Hayriye'den evvelki ananevî saraya pek çok tarafıyla benzemiyordu. Bilhassa o sarayın erkânı, milletle alâkalarını kesmiş hatta Abdülhamid'e bağlanarak millete karşı vaziyet almış bir feci güruh olarak görülüyordu. $\mathrm{Bu}$ güruhun içinde, milletin şan ve şerefleri ortasından çıkmış bir Gazi Osman Paşa bile kayboluveriyordu. Abdülhamid'in o büyük vâhimesi, etrafındaki bir ferdin milletle bir tek rabıtası olmamasıydı. Bu istediği aynen oluyordu. Yıldız'la millet arasında bir tek bağ kalmamıştı. Bu padişahı müsterih eden bu rabıtasızlık 10 Temmuz günü muallakta kalışı bâligan mâ-belâğ temin etmişti. Nitekim 10 Temmuz'dan sonra senelerce Yıldız adamları bu milletten ayrı insanlar gibi göründüler. Çoğu hakikaten anane-perest olan o adamların böyle bütün hayatları da muallakta kalışları, Abdülhamid'in nasıl bir şahsiyet olduğunu çok beliğ olarak gösteren bir manzaradır.

Üçüncü ve müspet bir müşahedeye geliyorum: Millet, o devirde ne istiyordu? Doğru bir müşahede olarak denilebilir ki hiç şüphesiz Vak'a-yı Hayriye'den evvelki vaziyeti zaten hatırlamıyordu. Ve bittabiî özlemiyordu da. Millet büyük mikyasıyla Reşid, Âli ve Fuad Paşa'lar, vezirlerden mürekkep bir Bâbıali olsa, Yıldız Sarayı'nın garip şekli kalkarak uslu, akıllı, âdil, evhamsız, adaletli bir padişah tahta geçse, ortalıktan hafiyelik, zulüm, iltimas, israf gibi manzaralar kalksa millî maksat yerine gelirdi. Millet herhâlde Jön Türklüğün vücudunu kulak vızıldaması kabilinden biliyordu. Milletin bir kısmı bu “Jön”leri masonlukla karıştırarak müteneffirdi de. Midhat Paşa'nın eskiden kalmış şehadeti herhalde halk arasında tesirli değildi. Tâif şehidinin aleyhinde "Mürted Paşa" ünvanlı bazı türküler, şüphesiz o zamanki sarayın halk arasına sokmaya çalıştığı fakat sokamadığı eserlerdi. Halk, Midhat Paşa'ya ne düşman ne dost, hakikatte kayıtsızd.

Denilebilir ki şayet Abdülhamid devrinde, Jön Türklüğe mukabil, Meşrutiyet aleyhdarı fakat Tanzimat taraftarı bu şekilde bir firka zuhur etseydi, 10 Temmuz'u yapmış İttihat ve Terakki'ye değil, O’na nasip olabilirdi zira milleti büyük bir mikyasta kendi arkasında bulurdu, fikrindeyim. 


\section{SIYYAŜ̂ HATIRALARIM}

1903 sonbaharında, Paris’te Monge Meydanı'nda Ahmed Rıza Bey’in küçük salonunda, ayağımı ilk defa politika âlemine attım.

19 yaşındaydım; Paris'e "Genç Türklük” ihtirası ile firar etmiştim. Sultan Abdülhamid-i Sânî’nin şahsına ve idaresine birkaç seneden beri düşmandım; memnu ve hafî hürriyet edebiyatı ile mütehassistim. Yalnız "Genç Türklük”, nazarımda fikirden ziyade bir his ve hayal sahası idi. Şiir gibi cazibeli bir şeydi. Paris’e kadar böyle düşünerek gelmiştim. Politikacılarla ilk muarefem, naklettiğim (gibi) ilk defa Ahmed Rıza Bey'in muhitinde oldu.

1903 'te Paris'te Genç Türklük, teskin edilmiş bir hâldeydi. Ahmed Rıza Bey, kıdemli bir reis sayılıyordu; O’nun etrafında Doktor Nazım, Samipaşazade Sezai Bey, Mısırlı Prens Mehmed Ali Paşa, bir de Ali Sâib Bey vardı. Doktor Nazım, o zaman henüz doktor değildi, tababet tahsil ediyordu. Bu pek küçük hizbin elebaşısı ve demirbaş unsuruydu, Sultan Abdülhamid'den para almamış ve satılmamışlardandı; Samipaşazade Sezai Bey İstanbul'dan bir müddet evvel çıkmış ve Paris'e yerleşmişti; Şura-yı Ümmet'e edebî üsluplu siyasî makaleleri O yazıyordu. Mehmed Ali Paşa, Sultan Abdülhamid tarafından evham sevkiyle İstanbul'dan çıkarılmış bir Mısır prensiydi; Genç Osmanlılı̆̆ın maruf hâmîsi ve nâmını hürriyete izafe etmiş olan Prens Mustafa Paşa'nın oğlu idi; Ahmed Rıza Bey’e ve neşriyatına nakden yardım ederdi lâkin pek politikacı bir zat değildi. Ali Sâib Bey Dağıstanlı müstafi bir zâbitti; Mısır'da müteehhildi; önce oradaki Osmanlı komiserliğine memur iken istifa etmişti. Karısı münasebetiyle hâli vakti yerindeydi; Mısır'da otururdu; bu mevcut hizbin Türkçe gazetesi olan Şura-yı Ümmet'i Mısır'da o tab ettirir ve paket hâlinde Paris'e gönderirdi.

Ahmed Rıza Bey’in riyasetinde iki gazete çıkardı. Biri Fransızca, avuç içi kadar, on beş günde dört sahife olarak çıkan Meşveret'ti; diğeri de yazıları Paris'te yazılıp kendisi Mısır' da basılan Şura-yı Ümmet'ti. Fransızca Meşveret'in yazılarıyla Prens Mehmed Ali Paşa'nın bir nevi kâtibi Sezai Bey'in bir nevi nedimi olan Amnekyan Efendi ${ }^{18}$ mukayyed olurdu. Şura-yı Ümmet'e ise hizbin âzâsı, imzasız yazılar yazardı. İmzasız yazmayı Ahmed Rıza Bey, kat'î bir kaide olarak vaz etmişti. Şunun-bunun, Sultan Abdülhamid'e imzasıyla şantajda bulunmasını men etmek için bu kaidenin zarurî olduğunu söylerdi. Lâkin hakikatte sebep başkaydi. Ahmed Rıza Bey cereyanın başında yalnız kendi görünmek isterdi; kötü muharrir olduğunu kendi de bilirdi. Gazetede, imzasıyla kimsenin parlamasını hoş görmezdi. Genç Türklüğün en derli toplu firkası bu idi.

Bir de Prens Sabahaddin Bey vardı. Paris civarında Soren'de otururdu. Saltanat hanedanından ve Damad Mahmud Paşa'nın oğlu olduktan başla mütefekkir bir zat da olduğu için kendi başına bir şef sayılıyordu. O’nun etrafında süt biraderi Fazlı Bey’den başka Hüseyin Siret, Kemal Midhat, Doktor Rifat, Sabri Bey'ler bulunurdu. Mamafih 1903'te Sabahaddin Bey pek sönük bir vaziyetteydi. Paris’teki kongrenin birçok para entrikaları içinde iflas etmesi kendisini

18 Pierre Anmeghian 
hem söndürmüş hem de bezdirmiş gibiydi. O ne gazete çıkarıyordu ne de risale neşrediyordu. Sadece mühim bir menkup gibi duruyordu.

Muarızlarına karşı müdafaa ettiği âteşîn bir hicviye, Tunalı Hilmi’nin Rezalet ünvanlı epeyce acayip bir eseri "Jön Türk” âleminin mahrem köşelerini ifşa ediyordu. Bu meyanda birkaç resimli mizah gazetesi de vardı ki bugün İstanbul'da çok tekemmül eden mizah gazetelerimizi gördükçe, onları bu nev'in uzaktan uzağa bir pîş-vâsı gibi görüyorum.

Bu koleksiyon tamam olduktan sonra arkadaşım Doktor Nazım'la ikimizin malı oldu. Uzun bir müddet muhafaza ettik. 1905 senesinin yazında, Hariciyede memurken Paris'e firar etmiş bir Âsâf Bey çıkıp satın almaya talip oldu. Biz de zarurette olduğumuz için dört yüz frank'a sattık. Bu koleksiyon ne oldu? Pek iyi bilmiyorum. Yalnız bu koleksiyonun - Şura-yı Ümmet gazetesini pek nâdir olan ilk nüshası da dâhil olmak üzere - Doktor Bahaeddin Şakir elde etmiş ve Meşrutiyet'in ilânından sonra İstanbul'a kadar getirmişti. Eğer o da kayboldu ise Jön Türklüğün en esaslı vesika unsurundan mahrumuz demektir. Çünkü hatıralar, vaktiyle günü gününe yazılmışşeylerin belagati kadar kudretli olamaz.

Hatıralar, tarihe en elverişli vesikalardan olmakla beraber şahsî oldukları için birer "görüş dairesi" olmaktan kurtulamıorlar. Bilhassa siyasî bir harekette âmil olmuşların hatıralarını kāri, sevk-i tabiî ile nalıncı keseri gibi muharririn kendine keser bir mahiyette görüyor. Bir hadiseyi naklederken kendi hesabına bir hisse ayırıyor gibi bir his veren hatıranüvisi de kötü bir vaziyettedir. Ben Jön Türklük içinde hiçbir şeref hissesi olmamış ve Meşrutiyet’ten sonra da vatana birdenbire dönmemiş, yalnız vaktiyle birçok gençler gibi o cereyana kapılmış, Paris’te beş sene Jön Türkler arasında yaşamış olduğum için kendi gölgemin bile geçmeyeceği bu devri o zaman gördüğüm, anladığım ve işittiğim gibi tasvir etmeye çalışacağım.

\section{JÖN TÜRKLER}

1908'den beri geçmiş olan siyasî tarihimizin, milletin kalbinde nasıl bir mevkii vardır? Bu mevzu beni kaç defa düşündürdü. Niçin düşündüğümü ve düşündükçe ne netice çıkardığımı bir defa da yazayım dedim.

1908 Meşrutiyetini îka eden hareket, o tarihten önce, okur-yazarlarımızın hayalinde, kalbinde ve başında adeta kudsî bir mahiyette idi. O kadar ki İkinci Sultan Abdülhamid "Yeni Osmanlıları" ve "Genç Türk" denilen insanları halkın nazarında küçültmek için her çareye başvurmuş lâkin küçültememişti. Bu sıfatları alınlarında bir damga gibi taşıyanlara karşı milletin kalbinde daima gizli bir saygı vardı. Abdülhamid'in nefyettirdiği bu cins adamlar menfalarında herkes tarafından daima mazlum sayılırlar ve sevimli görünürlerdi. Hapishanelerde bile devletin memurları onlara başka bir nazarla bakarlard1. Meşrutiyet'ten önce, beş sene Paris’te yaşamıştım; orada sefarethanenin memurları, Genç Türklerle görüşmekten kaçınırlar, lâkin kendilerini onlardan aşağı görürlerdi. Bunu yakından bilirim.

Yeni fikirler uğrunda, Midhat Paşa gibi öldürülmüş, Namık Kemal gibi İstanbul'dan 
memuriyetle uzaklaştırılmış ve gönderildiği yerde ölmüş olanlarsa mehîb ve esrarengiz birer kahraman görünürlerdi. Çok dikkat edilecek manevî bir hadiseyi de misal olarak zikretmek lâzımdır: Murad Bey firar ettiği zaman, milletin nazarında hudutsuz bir mikyasta büyümüştü, lâkin Padişaha itaat edip İstanbul'a döndüğü vakit bütün o şan ve şerefini kaybetmiş, sönmüş ve bitmişti. Demek ki millet Padişaha her isyan edeni seviyor hep itaat edeni hor görüyordu. Bu küçük vak'a ne kadar manidardır. Murad Bey İstanbul'a...

\section{TANIDIĞIM GENÇ TÜRKLER}

İsmail Hakkı Paşa - Anadolu ortalarından, galiba Amasya'dan bir zâttı. Genç Türklük zamanında sâbık askerî kaymakamlarından olduğu söyleniyordu. Abdüaziz'in hal'inde, Dolmabahçe Sarayı'nı saran kıtaât-ı askeriyenin birinde, küçük rütbede bir zabitmiş, o devrin Yeni Osmanlılık fikirlerini edinmiş, politikacılığından vazgeçmemiş, nihayet Rodos'a nefyedilmiş, oradan Rodoslu Şevket Efendi tarafından Avrupa'ya kaçırılmış olduğunu işitmiştik. Kendi babayânî, güler yüzlü, iyi kalpliydi. Gözleri daima ağrılıydı. Mısır, Paris, Cenevre ve Londra arasında seyahat edip dururdu. Ahmed Rıza Bey'in hasımlarındandı. Mamafih mukabil parti olan Sabahaddin Bey takımından da değildi. Genç Türkler arasında ortaca bir mevkii vardı. Meşrutiyet ilân edildiği zaman ilk dönenlerden biri oldu. Amasya'dan mebus çıktı. İttihat ve Terakki'ye muhalif bir vaziyet aldı. Sonraları galiba nefyedildi. Ancak Mütareke'de tekrar ortalıkta göründü. "Sulh ve Selamet” Fırkası'nın bellibaşlı reisi oldu. Sönük muhalif ve meşkûk milliyetperver olan bu acîp firka ile $\mathrm{O}$ da ortadan kayboldu. Bütün hayatında mutavassit derecede bir insan kald1.

Hoca Kadri - Fatih Hocalarından, Mısır'a, oradan Paris'e firar etmiş garip bir zâttı. Aslen Boşnaktı. Türkçeyi Boşnak şivesiyle konuşurdu. Tostoparlak, şişman, gözleri miyop ve pisliği marazî bir dereceydi. Senelerde hamama gidip yıkanmazdı. Kendisi leş gibi kokardı. Çok temiz olan insanlar, yanına varamazdı. Bilhassa lokantada, yanında yemek yemek istikrah verirdi. Emsalsiz denilecek bir derecede faziletkârdı; menâfi'-i maddiyeyi istihkar ederdi. Mısır prenslerinin hürmetine mazhar olduğu (hâlde) onlar tarafından bin türlü itina ile verilen atiyeleri reddettikten başka onlara aylarca gücenirdi.

Dölaspe Sokağı'nda bir küçük odada yaşar, Mouffetart Sokağı'nda fakir bir aşçı dükkânında yemek yer, gündüzlerini “Kalurizi de Lila” Kahvehanesi’nin bir köşesinde geçirirdi. Ziyaretlerine Prensler, Paşalar ve zengin insanların geldiğini gören kahve sahibi ve garsonlar bu yüzden kendisine hürmet gösterirlerdi. Asabî ve bedbindi. O kimseyi aramaz, her(kes) kendisini arardi. Medrese ilmiyle âlimdi. İbranice ve Lâtince'yi, Yunancaya kadar bütün lisanları bildiğine dair bir rivayet var idiyse (de) yanlıştı, bu rivayet filolojiye olan merakından kinayeydi. Maruf olarak İstinsaf unvanlı bir eseri vardı. Müteşevvikane ve ihtilâlcûyâne bir kitaptı. Girift bir üslûpta, sayfalarca süren uzun cümlelerle yazılmıştı. Hoca Kadri Efendi Mısır'dayken Kanun-ı Esasî diye bir gazete çıkarmış ve Sultan Abdülhamid'in aleyhinde fetvalar neşretmişti. Muhalifliğe tab'an müstaiddi. Temmuz İnkılâbı olduğu gece, adı henüz işitilen İttihat ve Terakki'ye muhalif olmuştu. Bilhassa Doktor Nazım'ın sabahlı-akşamlı ... denen düşmanı idi. Meşrutiyet'te 
memlekete dönmedi. Paris’te eski hayatına devam etti. Orada, Harb-i Umumî içinde öldü. Serâpa menfî ${ }^{19}$ olarak afif bir insandı.

Abdullah Cevdet - Arapgirliydi. Askerî Tıbbiye mezunlarındandı. Trablusgarp'a nefyedilmiş ve oradan Paris'e firar etmiş lâkin daha gelir gelmez Genç Türkleri iskât etmek için Ahmed Celâleddin Paşa'dan maaş almış, sükûta varmıştı. Lâkin bu maaş.., ${ }^{20}$

Paris sefiri Münir Paşa, Jön Türklüğün tamamıyla susmasını, menfaati iktizasından görmediği için ve Sultan Abdülhamid'in vehmini terk edecek kadar birkaç gazetenin çıkmasını ve bunları takip dolayısıyla tahsisat almak ve hafiyelik etmek istediği için Abdullah Cevdet'in maaşını kestirmişti. Abdullah Cevdet de kendi gibi maaşları kesilen İshak Sükûtî ve Tunalı Hilmi'yi alarak Cenevre'ye gitmiş, orada Osmanlı gazetesini neşretmeye başlamıştı. O zamana kadar intişar etmiş Jön Türk gazetelerinin en şiddetlisi bu Osmanlı gazetesiydi. Sultan Abdülhamid'in şahsına ve hayatına karşı en sert hücumlara giriştikten başka Abdullah Cevdet'in “Liberpana”ya çalan fikirlerini ve İshak Sükûtî'nin Kürt milliyetperverliğini de kurcalıyordu. Nihayet Abdülhamid bu gazetenin nâşirleri olan Abdullah Cevdet, İshak Sükûtî ve Tunalı Hilmi ile müzakere etmiş, bu üç Jön Türk'e de birer sefaret doktorluğu temin ederek Genç Türklüğün bu meşkûk alevini de söndürmüştü. Abdullah Cevdet, Viyana sefareti doktoru tayin edilmişti. Orada 1500 Frank hakk-1 sükût alarak ikamet ediyordu. Bir taraftan Saraya sadakat arizaları gönderiyordu. Bir taraftan da Fransızca şiir mecmuaları yazıyordu. 1903'te Abdullah Cevdet, bir ziyafet ve merasim mesârifi meselesinden dolayı Sefir Mahmud Nedim Paşa'yı tokatladı. Ve Avusturya hükümetinin müdahalesiyle Avusturya hududu haricine çıkarıldı. Saraya müracaat etti ise de uzun zaman cevap alamadi. Paris'e geldi. Bir müddet ümitli olarak bekledi. Lâkin Saraydan ümidini kesince o senenin kışında Cenevre'ye gitti. Küçük bir matbaa peyda etmişti. Cenevre'de önce Osmanlı'yı, sonra Içtihad' 1 çıkarmaya koyuldu. Bu patırtı ve gürültüsü bir sene sürdü. Münir Paşa İsviçre hükümeti nezdinde teşebbüse girişti. Abdullah Cevdet'in neşriyatının şantajdan ibaret olduğunu vesâikle mahkeme kapısında ispat etti. Davayı kazandı. Mahkeme Abdullah Cevdet'i İsviçre arazisi haricine çıkardı. Abdullah Cevdet, oradan doğru Paris'e geldi. Sosyalist matbuat vasıtasıyla epeyce gürültü çıkarttı. Paris’ten de doğru Mısır'a gitti. Orada bir taraftan göz hekimliği diğer taraftan matbaacılık ederek hayatını kazanmaya başladı. Meşrutiyet olunca da İstanbul'a döndü.

Abdullah Cevdet, Genç Türk hareketinin ilk muharriklerinden olmuştu. Bu harekete ayrıca da maruf olduğu softa düşmanlığı ve dinsizlik, azamî temeddün nazariyelerini karıştırmıştı. Lâkin fevkalade menfaatperest ve para karşısında zayıf ve hatta zelildi. Maruf olan teşebbüsâtından otuz sene rücu etmeyen bu adam, sebatın bir timsali sayılır. Gariptir ki bu derece sâbit olan bu insan, firkacılıkta, siyasiyâtta son derece dönekti, seciyesizdi. Bu dönekliği ve bu seciyesizliği yalnız paraya ve memuriyete karşı olan zaafından münbaisti.

19 “sürgün” mânâsınadır.

$20 \mathrm{Bu}$, Yahya Kemal'in devam etmediği bir cümlenin başı hissi vermektedir. 


\section{Tanıdığım Genç Türkler’e Mâbâd}

Edhem Ruhi - Adını gûnâgûn politikacılık cephelerinden işittirmiş olan Edhem Ruhi, ilk Genç Türk kafillesinin Bünyamin'i sayılırdı. Tıbbiye talebesinden iken Genç Türklük gürültülerine karışmış, maruf Tıbbiye takımıyla Trablusgarp'a sürülmüş, oradan Avrupa'ya kaçmış, neşriyata girişmişti. İshak Sükûtî’nin başlıca müridi ve muhibbi idi. İshak Sükûtî, Roma sefareti doktorluğunu, hakk-1 sükût olarak aldıktan sonra bir derece tezkiye-i nefs için Abdülhamid'den aldığı maaşın bir kısmıyla Osmanlı gazetesini kemakân çıkartmak için Edhem Ruhi'yi tavzif etmişti. Osmanlı, o tarihten itibaren Avrupa'nın muhtelif şehirlerinde karabatak gibi, zaman zaman çıktı ve kayboldu. Bu gazete, hakikatte Edhem Ruhi'nin şantaj vasıtasıydı. Gazetesini ve kendisini kerrâtla Sefir Münir'e satan bu derbeder çocuk, ihtilâlciliği kimseye vermez, bu iddia ile Mısır ve Avrupa arasında muttasıl mekik dokur, kendi gibi firarî olan Türklerin birçoğu ile itişip dövüşür, kendini bilhassa bombacı ve dinamitçi gösterirdi. Hiç sağlam ayakkabı değildi. İstanbul'da bıraktığı validesi, Abdülhamid zabıtası tarafından tevkif edilip hapishanede vefat etmişti. Edhem Ruhi'nin bu bir hazin tarafiydı. Mamafih O, bu hazin tarafını samimî hâlinde bırakmaz ve tafra-fürûşâne gürültüsüyle annesini Abdülhamid'in hapishanede nasıl idam ettirdiğini mübalâğalı ve lüzumsuz bir üslûpla ballandırır ve bu faciayı durup durduğu yerde inanılmaz bir şekle sokardı.

Edhem Ruhi, Mısır'da ve Avrupa'da temin-i maişet vasıtalarını tamamıyla kuruttuktan sonra Bulgaristan'a gitti ve Filibe'de yerleşti. Oradaki cemaat-i İslâmiye'nin mahallî politikasına karıştı. Filibe'de senelerce Balkan diye bir gazete çıkardı, nihayet o gazete ile oradan, Meşrutiyet cereyanına şiddetli bir alâka gösterdi. 31 Mart'ta ve onu takip eden Hareket Ordusu sevkiyatında Balkan gazetesinin neşriyatının çok faydalı ve nâfiz olduğunu söylerler. Edhem Ruhi, bu hizmetinin sayesinde, İttihat ve Terakki'nin yardımıyla, Balkan Harbi'ni takip eden TürkBulgar muhadeneti günlerinde, Sobran'a mebus gönderildi. Mebusluğu esnasında çevirdiği kirli entrikalarla kendini büsbütün berbat etti. Bulgaristan'da çok kötü bir nam bırakan bu adamın Balkan gazetesinin Bulgaristan Türkleri arasında bir intibah uyandırdığını en şedit düşmanları bile itiraf ederler. Bulgaristan'dan İstanbul'a nakl-i mekân ettikten sonra Edhem Ruhi büsbütün söndü. İsmi yalnız paraya müteallik kirli davaların arasında matbuat sütunlarında görünür oldu. Denilebilir ki politikaya başlayacağı bir çağda, hayatının defterini dürmüş ve politikacılı̆̆ını yıpratmıştı.

İshak Sükûtî - İshak Sükûtî’yi tanımadım. Lâkin Genç Türklüğün arasında bıraktığı tesir fevkalade idi. O hareket içinde yegâne fiil adamı ve yegâne hakikî baş sayılıyordu. Abdülhamid'e satılmasına rağmen ve vefatından seneler geçtiği hâlde bu tesiri devam ediyordu. Kendisinin Kürt menşeinden olduğu rivayet olunurdu. Vâkıa maruf resimlerinde bu 1rk tarafı sezilir. Hâlâ hatırasını muhafaza eden hayranları olması, bu şahsiyete müverrihin nazar-1 dikkatini celp edecek bir hâldir. Fikirce büyük bir farikası olmayan bu insanın ahlâkça da zaafı barizdir çünkü arkadaşları olan Abdullah Cevdet ve Tunalı Hilmi'yle müştereken Cenevre'deki Osmanlı gazetesini ve matbaasını Sefir Münir'e satmış ve bir daha hareket etmeyeceğine dair senet de vermişti. Herhâlde (o) devrede hakk-1 sükût almayı reddeden Hoca Kadri gibi beş 
parasız insanlarla O’nun arasında bir fazilet farkı vardır. Mamafih hayranları İshak Sükûtî’nin satılmasını da mazur gösterirler. O'na o derece bağlıdırlar. Nitekim bu hayranlık Meşrutiyet'ten sonra, O’nun cenazesini azîm bir alayla İstanbul'a nakletmekle de tecelli etti. Meşrutiyet'e yetişseydi İttihat ve Terakki'den mi olurdu, muhalefetten mi, bu pek kestirilemez. Çünkü O’nun kadar serkeşlerin İttihat ve Terakki içinde uysal ve mûtî birer insan oldukları görüldü; Temmuz inkılâbını takip eden vekāyi ve O'nun mizacı nazar-ı dikkate alınırsa muhalefetin muhtelif komplo harekâtına iştirak edeceği de hatıra gelir. Herhâlde "menfasında öldüğü daha iyi oldu" demek en doğru sözdür.

\section{DR. NAZIM VE HÂLID RÂŞID}

Paris'te ve İstanbul'da müteaddit dostlar edindim. Meşrutiyet'ten önce Paris dostlarımın başlıcaları Doktor Nâzım, Hâlid Râşid, İstamos, Salan? Kardeşleri, Guy Rubke, De Kostal'dı.

“Doktor Nâzım 'la aramda hilkat ayrılı̆̆ı vardı” diyebilirim. Zekâlarımızın çeşitleri başkaydı, ruhlarımızın ufukları başkaydı, temayüllerimiz başkaydı. Mamafih dost olmuştuk. Birbirimizi bulduğumuz zaman ayrılamazdık. Saatlerce konuşurduk. O’nun önce Ortolan, daha sonra Descartes sokaklarındaki lojmanının mutfağında beraber yermek yerdik. Muhasebelerimiz daima Jön Türklük güttürüşünün dairesinde idi. Kendisini coştura coştura ifade etmek firsatını benimle konuşurken iyi bulurdu. Konuştuğumuzu gören, kıyasıya düşmanmışız da kavga ediyoruz sanırdı. Bu üslûp Nâzım'ındı. Hatta muhabbetinin bir ifadesiydi. O’nca coşmak, kızmak değildi. Bir fikirde mutabık kaldığımız vakit bile yine yalnız müşateme gibi bir sinir hitabesi çekerdi. Çok açık kalpli bir insan olduğundan, beni Dâhiliye Nâzırı Memduh Paşa'nın Paris'te Jön Türk avlamaya çıkardığg 1 Muhtar'ın teklif ettiği maaşı reddetmiş olduğumdan takdir ettiğini, yoksa başka bir zaafı olmadığını tekrar eder dururdu. Mamafih Ulûm-1 Siyasiye Mektebi'nde şöyle-böyle açıldığımızdan sonra "okur ve anlar bir insan” diye not vermeye başladı. Bu ikinci takdirinde biraz nefsanî bir hesap da yok değildi. Çünkü ben o zaman, Paris’teki okur-yazarlardan Sabahaddin Bey'in yeni yeni nazariyelerine kafa tutuyordum. Nâzım ise Sabahaddin'in ahlâkını vatana bir defa muzır görüyorduysa ilmini on defa tehlikeli sayıyordu. O'nun ortaya attığı "adem-i merkeziyet"leri, "ferdâî terbiyeleri"? "Le Play" ve "Demolins"leri az-çok hırpalamaya heveskâr olanlara meylediyordu. Nazım'la Meşrutiyet'e kadar beş sene süren dostluğumuz, O’nun o zamanki Paris'te herkese dargın olmasından, benim de hayli dik kafalı ve kavgacı olduğum için, yaşıma ve başıma bakmaksızın, aralarımızda sin farkı olan diğer Jön Türklerle fazla anlaşmadığımdan, hâsılı birbirimize bu menfi yoldan yaklaştığımızdan, belki de biraz ikimizin de Rumelili olduğumuzdan geliyordu. Yoksa bu dostluk, hakikî bir yaratılış itilafından uzaktı. Nitekim Meşrutiyet olunca birbirimizi aramadık, sormadık ve bulmadık. Mütareke'den sonra birkaç defa eski dost ve yeni düşman gibi görüştük. Aramızdan on senelik bir sükût geçmemiş gibi, tıpkı Meşrutiyet'ten evvel Descartes Sokağı'ndaki mutfağında konuşur tarzda lâkin son zamanların siyasî zehirleriyle yüklü olarak beni bulur, bir köşeye çeker, içini dökmekten zevk alırdı. Galiba bir defa kendisine son on sene zarfında nasıl olup da görüşemediğimizi sordum. Bu sualim, vicdanında bir sızı husule getirmiş gibi bir-iki dakika sustu. Sonra coştu. Benim İttihat ve Terakki’ye girmediğimi ve girmemekle vatana fenalık 
ettiğimi, ondan bana gücenik olduğunu biraz uydurma bir mazeret olarak söyledi. Hakikat bu idi ki Nazım asıl hazzedici dostları Merkez-i Umumî’nin içinde bulmuştu. Ben O'nun için öteden beri iğreti bir dosttum.

Halid Raşid'i 1903 'te, Fransız talebesi arasında tanıdım. Jön Türklükle zerre kadar alâkası olmayan, tıpkı bir Fransız genci gibi Fransız muhitinde yaşayan, o vakit Louis le Grand Lisesi'nde okuyan bir gençti. Trablusgarp'tan nefy edilmiş bir müddei-i umumî muavini Raşid Bey'in oğluydu. Çerkesti ve çerkeslikle pek iftihar ederdi. Babasının isminden sonra kabilesinin ismini de kullanarak kendine "Hâlid Râşid Carım" dedirmeye çalışırdı. Halid biraz sonra liseyi terk etti. Tıptan, edebiyattan resme kadar muhtelif tahsillere heveslenmiş fakat hiçbir Fakülte'ye kayd olunmamış, babasını yalandan mektuplarla avutmaya koyulmuş, mektep tatillerini muntazaman heva ve hevesine sarf etmiş, Quartie Latin'in bilhassa Rus ve Lehli sanatkârları arasına dalmış, o muhitten bir daha çıkamamış, nihayet Musevî bir lehin kızıyla evlenmişti. Halid, muayyen bir istidat sahibi değildi. Yalnız edebiyata, sanata, tiyatroya nâdir görülür bir hararetle meyyaldi. Kendisinin dâhi olduğunu kaviyyen zannedederdi. Carm Sokağı'nda 5 numerodaki otelde bir odada otururdu. Odası serseri sanatkârların ziyaretgâhıydı. Bu içtimalarda Paris' in resim sergileri, konserleri, spor haberleri, bilhassa edebî neşriyatı ve tiyatro hadiseleri çok vukuf ve hararetle konuşulurdu. "Bu serseri ecnebi sanatkârları keşfetmek, Halid 'in mukadderatında vardı" diyebilirim çünkü bir kısmı kaybolunca diğer bir kısmı türerdi.

Halid'le içtiğimiz su ayrı gitmezdi. Uyuduğumuz saatler müstesna olmak üzere fasılasız bir edebiyat münakaşası içinde yaşardık.

\section{ÖMER NACİ - SAMİPAŞAZADE SEZAİ}

Ben kendisini 1907'de Paris’te tanıdığım zaman Ömer Naci otuz yaşında vardı. Orta boylu, esmer, gülümser yüzlü, daima konuşmaya başlayacak gibi canlı, rind tavırlı, giyi(ni) şinde ihmalkâr, oturup gezişinde ve yiyip-içişinde lâübâlî, kalender-meşrepliği derhâl göze çarpar bir adamdı. Sağ elini ekseriya yeleğinin omuz altından olan kısmına geçirir ve öyle konuşurdu. Dilinde hafif bir pelteklik mevcuttu. Sesi tatlı ve sıcaktı. Babayanî bir insandı.

Basit bir aile terbiyesi almış olduğu belliydi. Ülfet etmiş olduğu insanlar, güzidelerden değildi. Kendisinde zâhiren incelik, güzidelik, nezaket gibi hassalar yoktu. Maddî ihtiyaçları azdı. En fakir bir hayatın içinde mesut olabilirdi. Pis değilse bile temizliğe mütemayil olmadığı da anlaşılırdı. Traş ve hamam, tuvalet ihtiyaçları muntazam değildi. İyi giyinmekten, iyi yiyip-içmekten anlamazdı. Kuulü muntazaman sevmezdi. Lâkin bir işret meclisinde herkesten fazla içerdi.

Gençliğinin ilk senelerinden beri bulunduğu muhitlere hâkim olmuştu. Bir muhitte ikinci kalmak ve tâbî olmak şiârı yoktu; daima tabiatıyla teferrüt ve tagallüp ederdi. Edebiyat-1 Cedide şairleri arasında üçüncü derecede kalmış olmasıyla şahsiyetini tefsir edenler aldanırlar; Ömer Naci o zaman pek gençmiş; sâniyen zaten Edebiyat-1 Cedide muhitinde yaşamamış, sadece Servet-i Fünun'a manzumeler göndermiş. Vâkıa Edebiyat-1 Cedide'de birinci olacak meziyette değildi. Ömer Naci, muhitlerini kendine bend olan hayranlardan teşkil ederdi. Dost canlısıydı. 
Fârikalı bir insan olduğu muhakkaktı ve çabuk fark olunurdu. İdealist ve mütehayyil hilkatteydi. Ancak emel ve temayülleri belirmemişti. Şiiri zayıftı. Sevdiği ve daima tekrar ettiği şiirler arasında meselâ Fâik Âlî’nin “Ufûl Etmiş Mehasin Karşısında” ünvanlı bir manzume vardı. Bu manzume, Fâik'in diğer eserleri gibi isrî bazı lâfların yığıntısından mürekkep bir felsefe bulamacıydı. Mânâsı çok meşkûk olan bu manzumeye hayrandı. Makber'den okuduğu parçalar tumturaklu natıkanın ifadesi olan şeylerdi. Şiiri inşadına marazî bir derecede müptelâ idi. İnşâd tarzı da müfrit tumturaklıydı. Şiirin hangi nev'ini ve hangi çeşnisini beğendiği kestirilemezdi. Şiiri mutlak olarak severdi. Lisana vukufu yoktu. Sıra terkipli ve mânâları tekrar eden kelime molozuyla dolu cümleleri, pür-gûlukla seve seve söylerdi. Şiirden ziyade iki şeye bilhassa heveskârdı: Felsefeye ve hitabete. Edinmiş olduğu felsefe malumâtı malûm olan darülfünun usulünde olmaktan uzaktı. Descartes'i, Pascal'1, Spinoza'y1, Kant'1, Spencer'1 yeknesak bir hayranlıkla telâkki etmekten zevk alırdı. Bütün hevesine rağmen felsefeyi sistem dâhilinde bir sa'y ile benimsemeye hiç mütemayil değildi. Umumiyetle kitap okuması gayr-1 muntazamdı. Bir cümlede hülâsa etmek lâzım gelirse: Tenkit ve muhakeme meziyetinden mahrum ve sevk-i tabiî ile daima hayran bir adamdı. Hatipliğe meyli daha bârizdi. "Jorers'i bir mitingde ilk defa dinlediği vakit yeryüzünde idrak edebileceği zevklerin hadd-i azamîsine vâsıl olmuş, sermest bir hâlde idi. Sarah Bernhardt'1 ve Mone ...... ${ }^{21}$ 'i oynarken gördüğü gecelerde de aynı hâle düşmüştü. Nümayiş gevezeliğiyle meshurdu. Meydan adamı olmak için doğmuştu.

Çok izzet-i nefis sahibiydi. Prens, Paşa ve içtimaî sıfatları yüksekçe insanların karşısında hemen sâkit ve mağrur olurdu. İzzet-i nefsinin bir vesileyle ceriha-dâr olacağından korkardı. Böyle tesadüflerde adeta değişirdi. Hâli, müdafaaya geçmiş gibi ihtiyatkâr görünürdü. Böyle zevatla geçimsiz bir hâl alırdı. Basit bir sözden alınarak gururlu bir muarazaya atılırdı. Kibirsiz insanlar arasında ise tam kendini bulurdu; rind, lâübâlî, tabiî olurdu.

Ömer Naci, genç ölmekle beraber, “olacağını oldu” fikrindeyim. Meşrutiyet'in kahraman sınıfına karıştı. İttihat ve Terakki’nin bellibaşlı halk hatibi kesildi. Büyük halk kitlelerine saatlerce delidolu nutuklar söyledi. Orta seviyede politikacılardan vâsî mikyasta hayranlar edindi. Atılışlı hilkatini mesut edecek hadiselere bol mikyasta karıştı. Kendi yaratılışı dâhilinde felekten kâm aldı. Zannederim ki işaret ettiğim nakisalarından şahsiyeti tamamıyla belirdiği günlerde de kurtulamadı. Meselâ lisanı daima muğlak, karışık, tumturaklı kaldı. Şehzadebaşı'nda bir sahnede söylemiş olduğu bir nutkun, Kosova’ya Sultan Mehmed-i Hâmis'le gittiği vakit söylemiş olduğu diğer nutkun zapt olunmuş şekillerini gazetelerde görmüştüm; bu nutuklardaki cümleler, üslûpça ve mânâca Arapsaçı gibi şeylerdi. Bu cümlelerin haşivlerle mâlâmâl olduğunu lisanda en az zevki olanlar bile temyiz edebilirlerdi. Fikirlere gelince bir siyasî meslek nâmına tasnif edilmeleri güçtü: En geniş sosyalistlikten en müfrit saltanat-perestliğe kadar, en meşkûk dinsizlikten en hâşiâne diyanete kadar biribirine zıt düşüncelerin silsilesiydi.

İttihat ve Terakki'nin irfanları hayli mahdud olan âzâsının bile Ömer Naci’yi “ $O$ halk hatibidir, öyledir!" bir tarzda tarifleri vardı ki nazar-1 dikkatimi celp etmişti. Galiba onlar da Naci'nin sallapatiliğinin farkındaydılar. Ben Paris'te tanımış olduğum zaman namus, ahlâk,

21 Okunamamıştır. 
iffet meselelerinde lekesiz bir insan olduğuna kāni olmuştum. Sonra bozuldu mu, bozulmadı mı bilmiyorum. Teşkilât-1 Mahsusa çeteleriyle şark vilayetlerinde dolaştığı vakitler hakkında, hem de sağlam İttihatçı olan ve valiler lisanından şâyi olmuş şehadetler doğru ise, çete muhitlerinde bozulmuş olduğunu kabul etmek lâzımdır. Korkak mıydı? Hasud muydu? Bu noktayı da iyi bilmiyorum. Bâbıâli Vak'asına zorla ve sarhoş edilerek sevk olunduğunu bir İttihatçıdan işitmiştim. Herhâlde girdiği yolda cesaret şarttı. Hâir olsa da olmasa da cesaret göstermesi lâzımdi.

Âdî tabakada kalmasaydı, ettiği kadar temayüz edemezdi fikrindeydim.

\section{SAMİPAŞAZADE SEZAI}

Sezai Bey’in ismi, elli sene evvel, birinci sınıf olarak tasnif edilmiş dört edibin dördüncüsü olarak kafalara yerleşti. Kemal, Hâmid, Ekrem isimlerinden sonra Sezai Bey gelirdi. Öyle zannederim ki Sezai Bey, eserinin kuvvetinden ziyade bu tasnife girmek mazhariyetini siyaset, edebiyat ve hayattaki mevkiini aldı. Bu silsile içinde olmasaydı ehemmiyetini hayli mikyasta kaybederdi. Samipaşazade olmak, Namık Kemal'in Çamlıca' da edindiği temeyyüzlerin arasına karışmak nesep ve içtimaî mevkiiyle Recaizade ile Hâmid'in zümresinden ayrılmasıyla Sezai Bey'in vaziyetini - mukadderât.$^{22}$ nev'inden olarak tayin etmiştir”' itikadındayım.

Sezai Bey, ince ve mariz yapılı, vücutça her rüzgârdan ve ruhça her sadmeden incinir bir adamdı. Siyasiyatta değil, edebiyatta bile meydan adamı olmaktan çok uzaktı. Hayatın sadmelerine karşı muttasıl korunan bir hilkatte olduğu, ilk görüşte anlaşılırdı. İlk gençliğginden beri ömrü böyle geçmişti.

Memleketinin en güzide zümresinden olarak tasnif edildiği hâlde mevkiini lâzım olduğu gibi doldurmaya şahsî kifayeti olamamıştı. Vezir oğullarının tabiatı ise, Bâbıali'de kat ettikleri mertebeleri kat edememiş ve devlet ikbaline, zıyk-1 nefesten erememişti. Şairane nesri ise, arkadaşlarının arkasından yetişememişti. İki yolda da geri kalmıştı.

Sezai Bey, 1902'de hayatında hasıl olan bu mesafeyi doldurmak azmiyle Paris'e geldi. Gayet sükûn ve sekinetle ve ihtiyatla Jön Türklüğe karıştı. Yavaş yavaş Şûrâ-yı Ümmet'in başmakalesini muntazam olarak yazmaya başladı. Makaleleri şairane nesirlerdi; Çamlıca'nın yıldızları, Yıldız Sarayı'nın esrarengiz kapıları, kırmızı hafiye fesleri, selâmlık resminin yaldızlı üniformaları, Anadolu içerilerinde giden menfî kafileleri, Beşiktaş Karakolu'nun kanlı sopaları, Bâb-1 Zâptiye'nin heyulaları gibi edebî ve belîğ levhaları ve adeta mevzun okunacak gibi âhenkdâr cümlelerle doluydu. Abdülhamid usûl-i idaresini her an ihtirasla takip etmiş bir muhalifin, ateşinden ve alâkasından mahrum olan bu makalelerde, siyasî fikir kofluğu da bu yazılarda göze çarpardı. Abdülhalim Memduh'un Abdülhâk Hâmid lisanından "Sezai Bey, Şurâ-yı Devlet'e geçemediğinden Şura-yı Ümmet'e geçti!" demesi, Sezai Bey hakkında hakikat-1 hâli ifade etmese bile yazı itibariyle bir müşahedeyi gösterir mahiyettedir. Abdülhak Hâmid'in bir rencideliği zamanında hakikaten etmiş olduğu diğer bir tariz de bu nev'idendir. Sezai Bey'in

22 Kelime okunamamıştır. 
"Hâmid Bey bir şey bilmez, hatta bunu bana bizzat kendi söyledi!" demiş olduğunu Hâmid Bey'e taşıyan bir arabozucu, Makber sahibi, "Evet, bunu ben söylediğimi itiraf ederim. Sezai Bey, Istanbul'dan Avrupa'ya firar ettiği vakit beni buldu. "Şurâ-yı Ümmet'e birkaç makale yazsam Abdülhamid'den bir sefirlik koparabilir miyim?” dedi ve fikrimi sordu. Ben de "ben bir şey bilmem!" dedim" cevabını vermişti. Sezai Bey’in Jön Türklüğündeki süflîliğinin ve ateşsizliğinin sebebi hakikaten bu muydu? Bu hükmü vermek biraz zâlimâne olur. Lâkin herhâlde Sezai Bey'in Jön Türklüğe Nâmık Kemal gibi sırf ruhunun sevkiyle atılmış olduğunu söylemek de samimî bir tarihnüvislik olmaz. Sezai Bey, Namık Kemal hilkatinde olmaktan ziyade Ekrem ve Hâmid Beyler hilkatinde, yani mevcut usûl-i idarenin pisliklerine karışmaksızın... ${ }^{23}$ Onun için de muvafik bir mevki alıp mutîane ve uslu, akıllı yaşayacak bir insandı. Nitekim Sezai Bey'in bu yaratılışı Meşrutiyet'ten sonra kendini olduğu gibi gösterdi. Sezai Bey Madrid'e sefir olduktan sonra İttihat ve Terakki’nin faaliyetinden çekilmiş gibi, rüesası silsilesinden de çıktı; vaktiyle kat-ı meratibde ve edebiyatta arkadaşlarından geri kalmış olduğu gibi bu defa siyasiyatta da bir defa daha geri kaldı. Bu defa ihtiyarlığında, Abdülhak Hâmid Bey’e verilmiş olduğu şekilde "Hidemât-1 Vataniye" tertibinden maaş tahsis edilmekle, elli sene evvelki tasnifinin hükmü bir defa daha yerini buldu denilebilir.

Sezai Bey'in en bâriz fârikası olan ediplikte işaret olunan meziyetleri ilk defa küçük hikâye yazmak ve hassas olmaktı. Bir de İngilizce bilmek şöhreti vardı. Küçük hikâyeyi Türkçeye nakletmek, bir hizmettir. Hassas olmaya gelince, Sezai Bey hakikaten hassas bir insandi. İngilizceyi ise hiç bilmezdi, denilebilir. Bu şöhretine daima hayret etmiştik. Sezai Bey, Sami Paşa gibi şark belâgatine vukufuyla maruf, âlim bir vezirin oğlu olduğu hâlde lisana vâkıf hatta meraklı bile değildi; edebî sanatın bu cihetiyle ömründe meşgul olmamıştı. 1880 ve 90 arasında türeyen şairane lisanın muayyen ve mahdud kelimeleri mensure olsun, makale olsun, mektup olsun, her yazısında yeknesak bir bahisle göze çarpardı. Cümleleri hatibâne, yavaş ve âhenkdârd1. Teşbihler(le) dolu idi. Teşbih ve istiareleri hemen daima şafaklardan, gurublardan, yıldızlı gecelerden, şebnemlerden, veremli çehrelerden, fakat harc-1 âlem olmayarak Paşazade, nesrinde bahsederdi.

Çamlıca... Çamlıca... Sezai Bey’in nesrinde, fikrinde, sözünde, bütün varlığında hâkim bir unsurdu. Bir bahçenin manzarası, ortasındaki havuzun sathına nasıl müebbeden aksetmiş durursa, Çamlıca da Sezai Bey’in varlığına öyle aksetmiş duruyordu. Muayyen bir iklime bütün ömründe esir olmuş edipler arasında Sezai Bey hakikî bir numunedir. Yalnız Sezai Bey'in tasvir ettiği Çamlıca, Türkçe edebiyatta pâyidar olacak mıdır? Hatta şimdi bile kārileri müncezib ediyor mu? Burası şüphelidir. Öyle zannediyorum ki bu nakîsa ediplerimizden yalnız Sezai Bey’e has bir şey değildir. Yetmiş seneden beri vatanımızın hiçbir iklimi, hiçbir edibimiz tarafından devirlerce pâyidar olabilecek bir kuvvette edebiyata hakkedilemedi. Fikrimce sebebi budur: Türkçe edebiyatta üslûp iklimin değil, iklim üslûbun malzemesi gibi kullanıldı. Türk edipleri, başlarını edebiyatın boyunduruğundan kurtararak, sevdikleri şeyleri nakletmek rüştünü gösteremediler. Mesela bir Stendhal, şimâlî İtalya'yı ihtirasla sever, onu

23 Bu cümle yarım bırakılmıştır. 
anlatmak ateşiyle yazı yazar. Yoksa yazıyı vücuda getirebilmek için İtalya'nın renklerini ve şekillerini malzeme gibi kullanmaz. Bir Stendhal'ın vücuda getirmek istediği şey, şimâlî İtalya'dır, bir edebî üslûp değildir. Recaizade Ekrem Bey’in İstanbul peyzajlarını çok seven bir insan olduğu anlaşılıyor. Heyhât ki bu şair, bu peyzajları o kadar manzume ve o kadar mensuresinde gözlerimizi cezbedecek bir kuvvetle canlandırmıyor. Bilâkis sadece edebî yazı vücuda getirdiği hissini veriyor. Abdülhak Hâmid'in Hindistan'a hayran olduğunu biliyoruz. Lâkin tasvir ettiği Hindistan, mâr ve mugaylanlardan, 1şılı kaplan gözlerinden, arslan ve yılanlardan bir belâgat yığıntısı gibi görünüyor. Paul Verlaine'in, Şeyh Galib'den kalan “bâkisi güzâf-ı bir nihâye" müşahedesini tekrar ederek, "maadası edebiyattır!" dediği bir devrede bizim yeni ediplerimiz "esas edebiyattır, maadası hayattır, tabiattır" tarifinin cenderesinden dışarıya firlayamadılar. Yeniliklerin perde perde tekrar ettiği son otuz senede Türk edebiyatı, aynı dairede, gözleri kapalı olarak dönen bir dolap beygiri gibi daima "edebiyat"1n etrafında döndü. Edebiyata esir olmak, en sarih bir tabirle çocukluk ve mekteplilik devresidir. Sahih şiir ve sahih nesir ise ancak bundan sonra başlar. Eski şiirimizde Fuzûlî’nin bir Kerbela Mersiyesini, Bâkî’nin meşhur Süleyman-ı Kanunî Mersiyesini, Nedim'in birkaç gazel ve kaside ve şarkısını, Şeyh Galib'in Hüsn ü Aşk'ını pâyidar eden esrarengiz kuvvet, bu şairlerden birinin Hazret-i Hüseyin'i tam bir Şiî hararetiyle sevmiş olması ve o 1stırabını anlatabilmek için bir mersiye söylemesi; diğerinin, Süleyman-1 Kanûnî devrinin bittiğine hakikaten yanması; bir diğerinin Kâğıthane ve Boğaziçi'ndeki neşvesini haykırmak istemesi; bir diğerinin de Mevlevî cezbesini ifade etmek için çırpınması noktasındadır. Nitekim şu zikrettiğimiz şairlerin de bazı eserleri var ki bu meziyetlerden mahrumdurlar, yani “edebî eser" olarak vücuda getirilmişlerdir ve bu eserleri ancak divanları açtı̆̆ımız zaman hatırlayabiliyoruz.

\section{POLITIKA}

1908 yazında doğanlar, şimdi bu yaz tam yirmi yaşında bulunuyorlar. ${ }^{24}$ İsimleri Enver, Niyazi, Ahmed Rıza olan delikanlılarla, "hürriyet", "adalet", "uhuvvet” olan genç kadınlara tesadüf olunduğu zaman, bu zaman geçişinin ciddiyeti derhâl beliriyor. 1908 Temmuz’unda arabalardan, pencerelerden, balkonlardan "yaşasın” bağıranlar, sokaklarda bayrak taşıyanlar, yakalarına kokart takanlar, Cemiyet şubelerinin odalarında Kur'an ve revolver üzerine yemin edenler, bütün teferruatı yazılmak şartıyla, otuz-kırk cilde sığmayacak yirmi senelik bir kitabı bizzat yaşadılar da hâlâ bugün şöyle-böyle genç sayılırlar. Eğer görmek denilen ..., ${ }^{25}$ insanları mutlaka değiştirseydi bu neslin en kâmil kimselerden mürekkep bir cemiyet olması iktiza ederdi. Fakat hakikat-1 hal budur ki yirmi senede çok şey görmüş olmakla yontulmak bir tarafa dursun, o senelerin vak'alarını doğru dürüst hatırlamak bile bu devirde müşahede olunan faziletlerden değildir. Edirne'nin fethine, Kosova Meydan Muharebesi'ne, Yeniçeri Ocağı'nın menşelerine yahut da çok daha yakın zamanlara dair vesika arayıp bulamadıkları için teessüf edenler ve bu yoksunluğumuzu seleflerin ihmallerine verenler bir dakika kendi hâlimize baksalar, daha dünkü en mühim safhaların bu saate dek en meçhul işler gibi telâkki olunduğunu görseler meselâ ehemmiyeti hudutsuz olan şu 31 Mart İhtilâli'nin aslına dair

24 Bu ifadeden, bu satırların, Varşova'da yazıldığı anlaşılmaktadır.

25 Kelime okunamamıștır. 
söylenen sözlerin el'an muğlak, müphem adeta mâlâyâni hükümlerden ibaret olduğunu düşünseler, meselâ ucu-bucağı bulunmayan bir felâket silsilesinin başlangıcı olduğunu pek iyi idrak etseler, Halaskâr Vak'ası'nın bugüne bugün belirsiz birtakım gazete laflarıyla tefsir olduğunu göz önüne getirseler, “Bâbıâli Vak'ası"nın, Cihan Harbi’ne girişimizin, milleti on cepheye saçışımızın, hâsılı birçok esaslı safhaların hakkında muasırlarımız lisanından en basit malumât işitilmediğini hatırlasalar, seleflerden bize birçok vesikalar kalmadığını değil, bizim hafızamızın zavallılığına göre çok şeyler kaldığını teslim ederler.

Sadece hatıra olan hatıraları bir tarafa bıraktıktan sonra bu yirmi senenin fikir dağarcığ ne değerdedir? Bu zemin üzerinde bir kalem tecrübesi ilk olmakla beraber nadir ve istifadeli bir şey olur.

Ekseriya basmakalıp olan firka programlarını fikir vesikası olarak kullanmak sadedilliktir. 1908 hareketini kimler ve hangi fikirlerle vücuda getirdiler! Bu fikirler zamana nasıl şekillerle girdi? Yeni fikirler, nasıl ve ne gibi sâiklerden doğdular? İyi ve kötü ne neticeler verdiler? $\mathrm{Bu}$ fikirlerin ne derece doğru ve yanlış oldukları hakkında zamanın hükümleri ne oldu? İşte bu zeminde bir müddeayı yazacak muharrir, bu istikamette düşünürse sahih bir eser vücuda getirebilir. 1908 hareketini o geniş Osmanlı ülkesinin o kadar vilâyetinde ve aynı zamanda, birdenbire berhevâ gibi vücuda getiren ânî âmil hiç şüphesiz uzun bir devrin devamından hâsıl olan had derecede bir bıkkınlıktı. İdare-i Hamîdiye, artık ne olduğunu hissetmiş, artık yeni bir şey vaat edemez hâle gelmiş, ihtiyarlamış, kimsenin nazarında bir şerefi değil, bir sırrı bile kalmamış bir idare idi. Bunun için koca imparatorluğun havzası, havagazıyla dolmuş bir oda gibi, bir kibrit çakışla birdenbire parlayabilirdi. Hükümet tarafının bu hâlde bulunduğu, bir müteraifedir. Fakat tebeddülü vücuda getirenler ne düşünüyorlardı.

1908 Temmuz'unda ilk parlayan şahsiyet Niyazi, O’nu hemen müteakip Enver oldu. Muvaffakiyet belirdikten sonra Refik Bey'in, Karasu Efendi'nin, Talat Bey'in, Doktor Nâzım'ın, Suphi Bey'in, Rahmi Bey'in, Fethi Bey’in, Necip Draga'nın, Ömer Naci'nin isimleri yayıldı ve bir Merkez-i Umumînin vücudu hissedildi. Memleketin haricinde de birinin başında Ahmed Rıza Bey’in, diğerinin başında Sabahaddin Bey'in bulunduğu birer “Jön Türk” hizbinin varlığı haber verildi. İleri geri bütün bu isimler ve şahsiyetler, yeni bir hareketi değil, bilâkis imtidat etmiş bir devre karşı aksülameli takip etmiş insanlar telakki olunuyorlardı. Temmuz' da en yeni fikir, hayli eski olan Midhat Paşa Kanun-1 Esasî'si idi. En yeni tahassüsler Namık Kemal'in otuz seneden beri modası geçmiş olan edebiyatıydı. Kebir bir şey söylemesi iktiza eden o "edebiyat-1 cedide" hizbi, en büyük rehber olan Tevfik Fikret'inden, en kuvvetli mütetebbi sayılan Ahmed Şuayb'ına kadar Temmuz kalabalığına karıştılar; en feylesof ve okumuş sayılan Rıza Tevfik'in bütün tezahürü ise muhtelif lisanlarda ve mütenevvi mabetlerde parlak fakat kof nutuklar vermekten ibaret kaldı. Açılan devre, yeni bir damga izafe eden bir şahsiyet belirmemişti. Dürüst olmak için göz önünden uzak tutulmayacak bir noktadır ki yeni bir fikir, o mahşer ortasında bir tınnet kadar kıymeti hâiz olamazdı. Çünkü Osmanlı ülkesinin muhtelif milliyetler tarafından meskûn bir ülke olduğunu... 


\section{ZIYA GÖKALP}

Ziya Gökalp mustarip, mütehevvir ve asabîydi. Dedi ki: "Siz içimizde müstakil ve bîtarafsınız. Bu hadisede reyinizi civanmerdâne vereceksiniz! Türkçülügün, hükümetin himayesine mazhar olmasından başlıca mesul benim, Türk Ocakları'na olan muavenetlerden ben mesul sayılıyorum, Halide Edip Hanım, hükümetin emniyetini suiistimal etti, Türk milletini Anadolu'da boğmak isteyen Ermenilerin lehinde ve bizim aleyhimizde ağzını açmak cüretini gösterdi. Millete karşı ihaneti bir tarafa bırakıyorum lâkin en basit mânâsıyla bu bir suiistimaldir. Türk Ocağı Heyet-i İdaresi'ne haber vermeyerek, onu aldatarak bu savlette bulundu. Hükümet, Türk Ocağını kapamak ve suikast edenlere haddini bildirmek üzeredir. Ben fevkalade müşkül bir mevkideyim. Hükümetin bu darbesiyle Türkçülük de sönebilir. Gençlerden bu kadar taraftarımız var. Onları ne yapalım? Hükümetin darbesini beklemeden buna biz kendi aramızda bir karar vermeliyiz. O zaman resmî müdahaleye hacet kalmaz. Ne düşündüğünüzü söyleyeceksiniz!” Ziya Gökalp'e dedim ki: "Size fikrimi sarahatle söyleyeceğim! Ermeni tehcirinin aleyhinde alenen söz söylediği için Halide Hanım’ı millete ihanetle itham etmek doğru ve haklı olmaz. Bugün mukadderatımızın başında bulunuyorsunuz. Kudretiniz büyük olduğu için mesuliyetiniz de büyüktür. Ermeni işinde birçok Türkçüler, birçok Türkçü olmayan milliyetperverler, hatta sizin aranızdan birçok İttihatçılar, Halide Hanım gibi düşünüyorlar. Böyle düşünenleri hain ve milliyetsiz addetmek doğru olmadıktan başka nihayeti gelmeyecek olan bir buhranın çıkmasına sebep olur. İsviçre' de Sadri Celâl Bey nâmında sosyalist itikadında bir genç, Fransızca bir yazı ile bir ecnebi gazetesinde ağyâra hitap ederek Ermeni tehcirini tel'in ettiği için içtihadınızı söylemiştiniz. Halide Hanım böyle hareket etmedi, kendi muhitimizde, Türk Ocağı'nda Türklere hitap ederek bu işte nasıl düşündügünü söyledi; Halide Hanım'1 da aynı içtihatla itham edebilir misiniz? Azizim Ziya Bey! Hakikat budur ki Ermeni Tehciri işinde Merkez-i Umumî ekalliyettedir. Ermeniliğin vatanımıza savletine karşı başvurulacak tedbirleri birçok milliyetperverler başka türlü mütâlaa ediyorlar. Bu hadisenin birinci kısmı böyledir. Halide Hanım'ın Ocak Heyet-i İdaresi'ni haberdar etmeyerek, Ocak sahnesinden böyle bir nutuk vermesi kalıyor. Hükümeti ve Merkez-i Umumî’yi birdenbire şiddetten men etmekle çok iyi etmişsiniz. Hükümet, Ocağı bu iş yüzünden kapatsa ve Halide Hanım'ı ezse halka ve Avrupa'ya karşı artık memlekette, kendisini milliyetperverlerin tutmadığını, ortada yalnız kaldığını ispat etmiş olur; vatanımız büyük tehlikededir, düşman Boğaz'dan büsbütün çekilmedi, Kafkas cephesinden gelen haberler fenadır, bu harp tadını kaybetti. Böyle bir vaziyette daha geniş ve mütehammil bir kafa ile düşünmek lâzımdır. Halide Hanım'ın Türk Ocağı'ndaki nutkundan İstanbul'da büyük bir ekseriyet haberdar bile değil; hakikatte bu küçük bir hadisedir; birkaç gün geçmekle unutuldu bile. Hükümetin, asabiyetle birdenbire icraata geçmediği isabet oldu. Halide Hanım hakkında bizim bir karar vermemizi istiyorsunuz. Ben Halide Hanım hakkında nasıl düşündüğümü söyledim; mamafih sırf Ocağı ve Türkçülüğü kurtarmak için Halide Hanım'1 aramazdan atmak ve aforoz etmek isterseniz buna ben iştirak edemem; sebebini âşikâr olarak söyleyeyim: Sizin Merkez-i Umumî’deki âteşîn ve icraatçı kafalara itimadım yoktur çünkü bizim kararımızı ellerine bir hüküm gibi alırlar, fiil sahasına çıkarmaya atılırlar, o zaman bizim reyimizi tekrar sormazlar. Hülâsa mademki beni kenarda, müstakil ve bî-taraf 
bir arkadaş biliyorsunuz, düşünceme ve sözüme itimadınız var, Halide Hanım’ın sıkıfıkı bir dostu da değilim, benim düşünceme itimat ediniz. Bu iş sadece kapatılsın!” Ziya Bey, kāni olmamakla beraber hayli gevşemişti, yaratılışında çok iyi bir adamdı, Ermeni meselesi öteden beri ıstıraplarından biriydi: "Ermeniliğin canımıza nasıl kıymak istediğini Şark vilâyetlerimizde görmüştü; çok vatanperverdi. O akşam ıstıraplarını bir daha uzun boylu anlattı. Ertesi gün bir daha konuşmak üzere ayrıldık; sabahleyin İstanbul'a aynı vapurda indik. Bahsimizin çeşnisini kaybettirmemek için o gün ve o günün gecesini O'nunla beraber geçirdim. Bana çok itimadı vardı. Zannedersem söylediklerimi Merkez-i Umumî’ de benimseyerek ifade etmiş. İş savsadı. Yalnız Halide Edip Hanım'a karşı şedit bir kin bâkî kaldı.

O aralık Halide Edip Hanım'a birkaç yerde tesadüf ettim. İyi görüştük. Bir gün de Fazlıpaşa'daki küçücük evine ziyaretine gitmiştim. Lâkin geçen meseleyi asla açmadım. Kendisi ile epeyi dost olduk. Ülfetimiz tabiîleşti. O küçücük evin denize nâzır salonunda Adnan Bey, Nakıye Hanım, Hamdullah Suphi, Yusuf Akçura birleşirdik, bazen Gomitas Vartabed gelirdi; Anadolu havalarını, eski Ermeni dualarının bestelerini, kendi ağızlarını teganni ederdi. Çay içerdik, edebiyata ve sanata dair konuşurduk.

\section{ILK HABER}

Akşamüstü Köprü’nün Haydarpaşa-Kadıköyü İskelesi üzerinde bulunuyordum. O iskelenin her akşam malûm olan izdihamı henüz başlamamıştı. Büyükada'ya gidecek istimbotlardan birine bakıyordum. Çünkü o sene, Yating Kulüp’te ikamet edenlerin bir dost istimbotuyla Ada'ya gidip gelmeleri âdet olmuştu. Bilhassa Maliye Nâzırı Cavid Bey, her Ada'dan indikçe birçoğumuzu aramak nezaketini gösterir akşam da beraber avdet etmemizi rica ederdi. Bu seyr ü sefer münasebetiyle görüşür, konuşur, güler, eğlenir, vakit geçirir, günün siyasî haberlerini alır, hoş bir vakit geçirmiş olurduk. Bu istimbot musahabelerinin reisi hemen daima Nuri Bey'di.

O günlerde kafam neyle meşguldü bilmiyorum. Lâkin harbi hiç düşünmüyordum. İçine atıldığımız günden beri er geç fecî bir şekilde biteceğini, dört sene zarfında bin defa tahayyül etmiş olduğum o badirenin nihayet bulduğunu, onu hiç düşünmediğim bir akşama tesadüf etti. İskele üzerinde beklerken, birkaç seneden (beri) gözden kaybettiğim ve ortalıkta hiç görmediğim bir eski Paris âşinası birdenbire koluma girdi. Çok mühim ve tehlikeli bir haber verir gibi ağzıyla kulağıma yanaştı.

- Yaman havadisler var! İş bitti!

dedi. Yüzüne baktım. Ne dediğini daha sarih anlamak istediğimi sordum.

- İş bitti. Bulgar cephesi çözüldü, yukarıdan Alman ve Avusturya cephelerinin çözülmek üzere oldukları da söyleniyor, harp bitti! Aman benden işittiğini kimseye söyleme. Zannederim patırtılı günlere giriyoruz!?

Söylerken çok müteheyyiçti ve mâlâyâni bir haber vermediği hissolunuyordu. Yerimde mıhlanmış gibi duruyordum. 
Bu haberi böyle nâgehanî bir sadme gibi kulağıma getiren âşina, Paris'te, daha 1905'te tanımış olduğum, Meşrutiyet'e kadar Quartier Latin kahvelerinde görüştüğüm, sonra İstanbul'da nadiren tesadüf ettiğim, bir taraftan komisyonculuğa, diğer taraftan da İttihat ve Terakki muhalefetiyle vakit geçiren, Mahmud Şevket Paşa'nın katlini müteakip Sinop'a nefyedilen, sonra oradan getirilen, yüzbaşılıktan çıkarılmış veyahut çekilmiş olan Tevfik’ti. Kendisi “.... ${ }^{26}$ Tevfik” diye yâd edilirdi. İriyarı, İstanbul çocuğu, Avrupa' da yetişmiş olduğu hâlinden belli, muhalefet sar'asına tutulmuş, o yoldan mevki, servet edinmeye heveslenmiş bir politikacıydı. Daha Paris'teyken Sabahaddin Bey'e intisap etmiş ve Meşrutiyet ilân edilince O'nun tarafından İzmir('e) gönderilmiş ve orada Doktor Nâzım tarafından tevkif ettirilerek kışlada isticvaba maruz kaldığg gazeteler tarafından haber verilmişti. O patırtılı günlerde kısa süren bu maceradan sonra Tevfik, bir türlü parlayamamış, mamafih İttihat ve Terakki'ye karşı olan garezinden de vazgeçmemiş, esas mahreki Sabahaddin Bey olmak üzere, muhalefet hareketlerinde karabatak gibi bata çıka yaşamıştı. Tevfik, fikirce ve irfanca hayli âdî olmakla beraber cin fikirli, kulağı delik, hâdisâta karşı hassas bir adamdı. Daima Tokatlıyan'ın, Lebon'un, Cenyo'nun camları önünde görünen çehrelerindendi. Herhâlde uyanık bir politikacıydı. Sonra 1925 'te, Ankara'da “Tarikat-1 Salahiye”, işinde sehpada ikmâl-1 hayat etti.

İşte harbin bittiği haberini ilk defa O'ndan aldım. Bu haber kafamı fena bir şekilde uyandırmıştı. Tevfik’ten ayrıldıktan sonra bir tanıdığa tesadüf etmek iştiyakıyla etrafıma bakınıyordum. Bana öyle geldi ki vapura gidenler arasında hâl ve tavrı iyi sınıftan olduklarını sezdirenlerin simaları endişeliydi ve galiba bu kara habere muttali' diler. Birkaç dakika dolaştım. Birdenbire iskele arkasında, istimbotların yanaştığı Galata Rıhtımı üzerinde, Cavid Bey’in istimbota gelip giden Adalı aşinalardan bir grubun toplandığına gözüm ilişti. Aralarında Hariciye Nazırı Nesimî Bey, Celâl Sâhir ve yanılmıyorsam Nurican ve Hallaçyan Efendiler vardı. Onlara doğru gittim. İçimi nâmütenahî bir üzüntü ile dolu olduğu hâlde ağzımı bıçak açmıyordu. İşittiğim haberin aslını sormak için lisanıma kesel ârız olmuştu. Hepsinin arasında en ziyade düşünceli Celâl Sâhir’i gördüm.

- Bulgar cephesine dair bir haber işittin mi?

dedim. Çok durgun ve mükedderdi.

- Evet, Bulgar cephesi çözülmüş. Berbat bir safha başlıyor.

dedi. Konuşmaya koyulduk.

Celâl Sâhir'in o aylarda İttihatçılığı hayli gevşemiş, ticaretteki işleri bozulmuş, kazandığı beş-on parayı Büyükada'nın bakara masasında bırakmış olduğunu yakından bilirdim. Mamafih kendisini önceleri şiddetle tenkit etmiş olmama rağmen kumardaki felaketlerinden beri merhamet ve şefkatle telakki ediyordum. Celâl Sâhir, meyusâne mütâlâalardan sonra:

- Mamafih bu harbin umulmaz manzaraların görebiliriz. Hüküm vermekte istical etmemeli; belki de gelen haberlerde mübâlağa vardır.

diyordu. 
Biz konuşurken Cavid Bey’in istimbotu da yanaştı. Cavid Bey’in bu akşam Ada’ya geleceğini söylediler. Kara haberi teyit eden bu alâmet üzerine oradakilerle beraber istimbota girdik ve Büyükada yoluna çıktık.

Yolda Nesimî Bey’le görüşüyorduk. Tarih bazen ne yaman manzaralar gösterir? Bunu şimdi naklederken, herhangi bir kārin bi-hakkın inanmayacağını farz edebiliyorum. O fecî haberin İstanbul'a geldiği günde Osmanlı Saltanatı'nın Hariciye Nazırı ile yan yana bulunuyordum. Çok terbiyeli ve nazik lâkin korkak, çekingen, mutî olan bu zâtın vak'aya dair Celâl Sahir'den az malumâtı vardı. İhtimal, yalnız kendisinin değil riyaset ettiği Nezaretin de - Alman sansürünün dehşeti altında - net haberlere dair kulağı delik olmadığı belli idi. İki saatten fazla süren Ada yolunda Nesim Bey'in ağzından işitilen sözlerin en harikalısı olarak zihnimde bu söz mahkûk kaldı. Nesimî Bey bana gayet ihtiyatla:

- Paşa'nın hangi gün geleceğine dair bir malumâtınız var mı?

dedi. Talat Paşa'nın Berlin'den döneceği günü soruyordu.

- "Nasıl? Beyefendi, bilmiyor musunuz?"

dedim. Zavallı adam hakikaten bilmiyordu. Kendisinin o günkü hâlini çok ketum ve bildiklerini sezdirmez bir adam rolünü ifa etmiş olduğuna kāni olmak isterdim. Lâkin hakikat hiç bu değildi. Nesimî Bey’in dünyadan haberi yoktu O gün Celâl Sâhir de aynen...

\section{ALİ KEMAL}

Ali Kemal'i, on dört sene sürmüş bir muarefeyle, Paris'te ve İstanbul'da tanıdım. Ne muayyen bir ideali, ne sarih bir müddeası, ne yüksek bir zekâsı, ne iyi bir irfanı, ne kuvvetli bir seciyesi, ne metin bir ahlâkı, ne de tam bir azmi olan bu adam Meşrutiyet devrinde "Tek başına bir kudret" olduğunu ispat etti.

Bu şahsiyeti pek yakından tanımış olanlar, hayranlıktan uzak bir hisle severlerdi. Çünkü şen, pür-gû, lâubâli, "bön” denilecek kadar safdil, çok sevimli bir tarzda gülünçtü. Bu hâliyle, en ziyade kırdığı dostlarını bile gülümsetir, yumuşatır, nihayet müsamahakâr ederdi. Hoş ve sıcak bir sesi vardı. Eski İstanbul lehçesiyle pek iyi konuşurdu. Açık, senli-benli, gülüşlerle karışık, mübalâaya meyyal olan konuşuşu ile kanaat bahşetmez, sadece neşelendirirdi. Çok kıvrak ve hususi olan gülüşleri, varlığının en güzel tarafı idi. Dinlemek hassasından mahrumdu. Konuştuğu insanların cümlelerini sonuna kadar dinlemez, cümle ortasında bir fikre hatta bir kelimeye saplanır, birdenbire coşar, "haydi azizim, bırak mîrim, birader ne diyorsun?... Ha ha ha ha ..." yollu kendine pek ziyade, pek has bir şive ile yarım yamalak dinlediği fikradan bambaşka bir bahse girer, sözü mecrasından uzaklaştırırdı. Bir gün kendisine Büyükada vapurunda tesadüf etmiştim, o gün de bir mecmuada Köprülüzade Fuad'in Mevlânâ Celâleddin-i Rûmî’ye dair bahsettiği yeni bir vesika gözüme ilişmişti; vapur daha iskeleden kalkmamışken Ali Kemal'e bu vesika hakkında bir cümle söylemeye çalıştım, cümlenin nihayetini ancak bir buçuk saat sonra Büyükada İskelesi'ne vardığımız zaman getirebildim; "Köprülüzâde Fuad, Mevlânâ Celâleddin-i Rûmî’ye dair yeni bir vesikadan bahsediyor” diye başlarken Ali 
Kemal cümlenin daha ilk kelimesine dokundu, birdenbire feveran etti: “Köprülü! Ah mîrim, ne Köprülüsü birader? Ahmed Refik herifi berbat etmiş, yazdiğl yaveleri okudum” diye bir girizgâh açtı. Ahmed Refik'in Köprülü Mehmed Paşa 'ya dair yazdiğı bir tetkikten bahsediyordu"27 lâkin bu münasebetle Ahmed Refik'a girişti, O’nun muharrirliğini, şahsını, hayatını, vapur Kınalı'ya gelinceye kadar fasl etti. Ben cümlemi itmam etmeye bir daha teşebbüs etmedim, “Köprülüzade..." der demez müthiş ${ }^{28}$ coştu, Köprülüzade Fuad'a fena kızgınmış, sövmediği bir tarafını bırakmadı, bu hicviye de hayli sürdü. Cümlemi itmam etmeye bir daha savaştım: "Mevlânâ Celâleddin-i Rûmî’ye dair..." derken Ali Kemal, biraz evvelki hiddetinin bir aksülameli olarak bir kahkaha salıverdi: “Ayol, ne Celâleddin-i Rûmî'si? Her şey bitti, şimdi de bir Mevlânâ çıktı. Herif Fârisî yazmış, Bu da mı Türkçü? Mevlânâ'nın bizim edebiyatla ne münasebeti var?" diye yepyeni bir bahis çıkardı. Büyükada İskelesi’ne yanaştığımız vakit ben cümlemin sonunu getirdim lâkin yol da mübahase de bitmişti. Muhatabını dinlememek, mühimsememek Ali Kemal'in en bariz bir nakisası idi; Mamafih kuvveti de bu nakisadan geliyordu. Etrafını dinlese ve mühimseseydi en coşkun atılıcılığına halel gelirdi.

Ali Kemal hiç Türk’e benzemez, şimal İslavını andırır, açık sarı, iriyarı, çevik, sıhhatli... ${ }^{29}$

\section{MADRID VE ISPANYA}

Hüküm Muahedemizin projesinde son defa talep ettiğimiz 6. ve 21. maddeler üzerindeki tadilâtın muvafik olduğunu izah eden rapor, İspanya Hariciye Nezareti Umûr-1 Siyasiye Müdüriyet-i Umumiyesi tarafından tanzim edilip muahede projesiyle birlikte Heyet-i Nuzzâr'in tasvibine iktiran etmek üzere, Hariciye Nazırlığı makamına sevk edilmiştir.

Son hükümet tebeddülünden ve Hariciye Nazırlığının yeniden ihdasından beri muahede ve mukavelelerin intacı hususunda takip olunan usule göre yeni Hariciye Nazırı Duca d'Alba'nın muahede projemizi Heyet-i Nuzzâr'a bizzat tevdi' ve itilâfımızı ikmal etmesi icap etmektedir. Müşarünileyhin son hafta zarfında Paris'e seyahat etmiş olması, projenin imzalanmak emri ile birlikte Ankara'daki İspanya sefirine gönderilmesinde kısa bir teahhur vukua getirdi. Nazır avdet ettikten sonra bizzat mülâkat ederek bu hususun tahakkukunu temin edeceğim.

Arz ettiğim üzere Hariciye Kâtib-i Umumîsi Mösyö Palaso Umur-1 Siyasiye Müdürlerinden Kont Saint İsteban Kanonto ile sebk eden müzâkerât itilâfa müncer olmuş ve son muamele olarak Heyet-i Nuzzar'ın tasvibi kalmıştır.

Duca D’Alba Hariciye Nezareti’ne tayin edildiği vakit görüşmeye gitmiş ve talep ettiğimiz tadilât hakkında izahat vermiş ve müzakereye memur zevatla anlaştığımızı izah etmiştim. Müşarünileyh, işin bir an evvel intaç edilmesi için muavenette bulunacağını ve Kral Hazretleri'nin bu hususta bendenize sebk etmiş olan va'dinin tahakkuk edeceğini, bilhassa dostane bir lisanla ifade etmişti. Bunun için yeni bir engele tesadüf etmeksizin emr-i devletlerini kariben yerine getireceğimden ümitvarım.

27 Kastedilen kitap şudur: Ahmed Refik, Köprülüler, Kitaphane-i Askeri, İstanbul 1915.

28 Metinde bu kelimeden sonra "bir" kelimesi gelmektedir. Fakat mânâ bozulduğu için yeni yazıya aktarılmamıştır.

29 Metin burada kesilmektedir. 
1- Hukuk-1 Hükümrâniye taalluk eden 21. maddede kabul edilen şekil hakkında tereddüt hâsıl olduğu beyan buyrulmaktadır. Yeniden çetin bir müzakereye maruz kalmamak için İspanyol teklifinin kabulünde mahzur olmadığını mamafih tarafımızdan teklif olunan metnin kabul ettirilmesi tercih edileceğine dair emr-i devletlerini telâkki etmiştim. Fakat bir defa tarafımızdan teklif olunan metin üzerinde müzakere etmeyi münasip gördüm. Teklifimiz kabul olunmakla bu cihet de netice-pezîr oldu.

Kabul olunan metni ...... numaralı ..... tarihli ${ }^{30}$ tahrirât-1 devletleriyle gönderilen zîrde münderiç metindir:

2- Gerek evvelce ve gerek 6. ve 21. maddelere mütedair bilâhare telâkki ettiğim talimât-1 devletleri mucibince icra edilmiş olan tadilâtı muhtevî muahede projesini mektub metni ile birlikte, Heyet-i Nuzzâr'ın tasvibini müteakip Nezaret'in imzaları verileceği gün, Nezaret’te ilk defa olmak üzere karşılaştırarak posta ile takdim edeceğim.

İktidar mevkiinde vuku bulan son tebeddül ile İspanya'nın en vahim ve şümullü bir ihtilal arefesinden en sakin bir intikal devresini geçtiği şüphesizdir. Zahiren Madrid sokaklarında talebe nümayişlerinden ve piyasada pesetanın sukutundan ibaret görünen hadise, ledünniyâtı itibariyle tehlikeli bir buhran silsilesi açacak mahiyette idi.

General Primo de Rivera'nın sivil ve askerî politika cereyanlarında yetişmiş, bu memleketin hükümet tagallüblerindeki ruhiyatına çok vâkıf, aynı zamanda bu oyunlarda çok üstat olduğu bu vak'aya dair hükümet tarzının her tedbiri kullandıktan sonra ancak son dakikada İspanyol efkâr-1 umumiyesinde.... ${ }^{31}$

Diktatörlüğün, İspanya'da istirahati temin etmiş, Fas işinde muvaffak olmuş ${ }^{32}$, Katalonya'daki ayrılıkçı hareketi bastırmış, dâhilde müesses bir inzibatı temin etmiş bir idare olduğunda şüphe edilemez. Nitekim General Bede'nin Başvekâlete sâbık usûl-i idarenin tazyikātını kaldırmaya başladığı vakit, tahliye edilecek siyasî mevkuf olmak üzere Majorka Adası'na teb'id olunmuş, bir talebe reisi getirtmekten, şiddetli nümayişte bulunmuş birkaç nümayişçi talebe serbest bıraktırmaktan, .....'da politika müsademelerinde bulunmuş bazı zabitleri ve neferleri...

İktidar mevkiinin geçirdiği son tebeddül, fevkalade bir derecede vahim olduğu hâlde azamî bir sükunetle vâki oldu. Bu kadar hayret edilecek bir inkılâp kolaylığı(n1), İspanya'nın geçen asırda en fazla dâhilî ihtilâl görmüş, büyük tecrübeler edinmiş, dâhilî ihtilâli görenlerin de, ihdas edenlerin de bu hususlarda üstad olmuş siyasiyûndan olduklarını teslim etmek suretiyle izah etmek mümkündür.

General Primo de Rivera'nın iktidar mevkiinde tutunabilmesi için her tedbiri kullandığını ve istifasını ancak son imkânsızlık karşısında verdiği.... ${ }^{33}$

30 Bu kısımları Yahya Kemal boş bırakmıştır.

31 Metinde cümle bu hâliyledir.

32 https://en.wikipedia.org/wiki/Spanish_protectorate_in_Morocco

33 Metin burada kesilmektedir. 